Portland State University

PDXScholar

Summer 7-26-2018

\title{
Environmental Justice in Natural Disaster Mitigation Policy and Planning: a Case Study of Flood Risk Management in Johnson Creek, Portland, Oregon
}

Seong Yun Cho

Portland State University

Follow this and additional works at: https://pdxscholar.library.pdx.edu/open_access_etds

Part of the Urban Studies Commons

Let us know how access to this document benefits you.

\section{Recommended Citation}

Cho, Seong Yun, "Environmental Justice in Natural Disaster Mitigation Policy and Planning: a Case Study of Flood Risk Management in Johnson Creek, Portland, Oregon" (2018). Dissertations and Theses. Paper 4502.

https://doi.org/10.15760/etd.6386

This Dissertation is brought to you for free and open access. It has been accepted for inclusion in Dissertations and Theses by an authorized administrator of PDXScholar. Please contact us if we can make this document more accessible: pdxscholar@pdx.edu. 
Environmental Justice in Natural Disaster Mitigation Policy and Planning:

A Case Study of Flood Risk Management in Johnson Creek, Portland, Oregon

by

Seong Yun Cho

A dissertation submitted in partial fulfillment of the requirements for the degree of

Doctor of Philosophy

in

Urban Studies

Dissertation Committee:

Connie P. Ozawa, Chair

Sy Adler

Heejun Chang

Masami Nishishiba

Portland State University

2018 
(C) 2018 Seong Yun Cho 


\begin{abstract}
This study aims to explore the possibility of environmental justice as social consensus and an institutional framework to reduce socioeconomic differences in natural disaster vulnerability through a case study of flood risk management in Johnson Creek, Portland, Oregon. First, by analyzing institutions, policies, and currently ongoing flood mitigation projects, this study investigates how federal and local governments are addressing and responding to current flood problems. Second, through flood expert surveys and GIS spatial analysis, this study examines various factors that contribute to communities' susceptibility to flood risks, and whether there exist spatial differences between physically and socioeconomically vulnerable communities within the Johnson Creek area. Lastly, this study conducted comparative analysis of perceptions using Qmethodology to explore the diverse range of meanings and understandings that flood experts and urban practitioners construct in relation to the dilemmas of environmental justice in flood mitigation practice. The findings of this study indicate that institutional blind spots and barriers in natural disaster mitigation policy and planning can be generated by flood experts' and urban practitioners' different understandings of vulnerability, different interpretations of human rights, and different perspectives on the extent of institutional responsibility to assist socioeconomically vulnerable populations.
\end{abstract}




\section{Acknowledgements}

I would like to express my deepest appreciation to my advisor Professor Connie Ozawa who was more than generous with her expertise and precious time. Thank you so much for all your support and guidance throughout the years. Besides my advisor, I would like to thank the rest of my committee members, Professor Sy Adler, Professor Heejun Chang, and Professor Masami Nishishiba for their insightful comments, constructive suggestions and positive motivations.

I wish to thank all my fellow graduate students and friends who supported me to strive towards my goal. Last, but most importantly, I would like to thank my parents and my wife for their unreserved love and devotion. Words cannot describe how grateful I am for all the sacrifices you have made on my behalf. This journey could not have been completed successfully without your wholehearted support and warm encouragement. 


\section{Table of Contents}

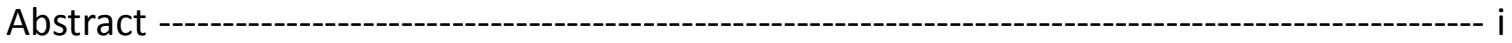

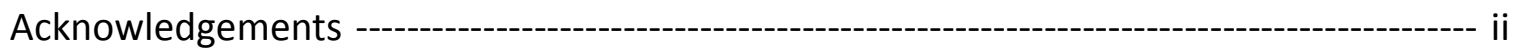

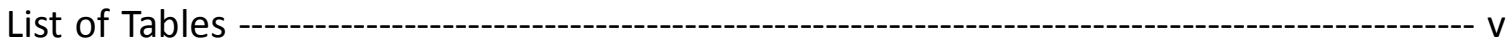

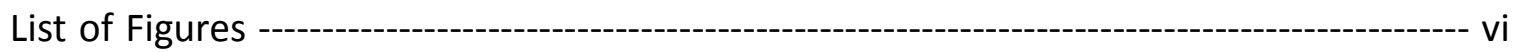

1. Introduction: Socialization of Natural Disaster Problems ------------------------------- 1

2. Theoretical Background of Natural Disaster Mitigation ---------------------------------------- 6

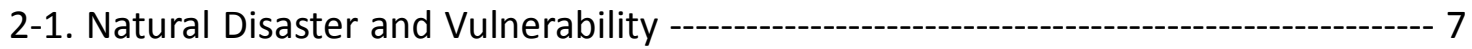

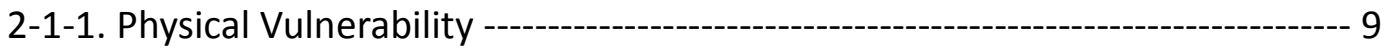

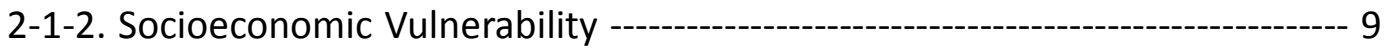

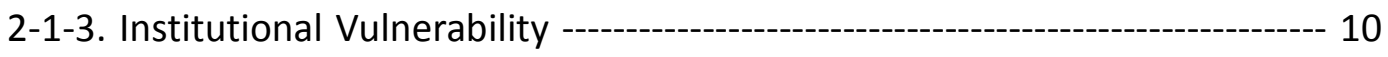

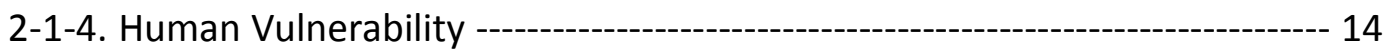

2-2. Natural Disaster and Environmental Justice --------------------------------------- 16

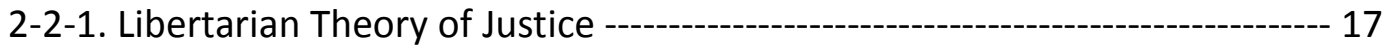

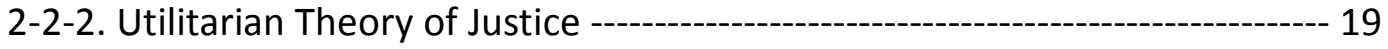

2-2-3. Egalitarian Theory of Justice -------------------------------------------------------- 21

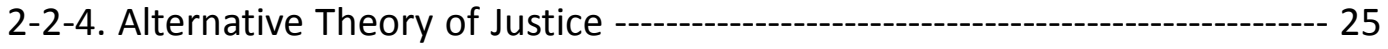

3. Case Study: Flood Risk Management in Johnson Creek, Portland, Oregon -------------- 29

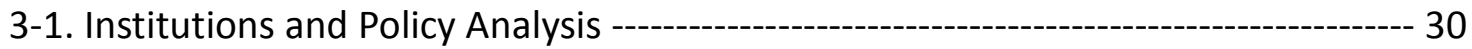

3-1-1. Federal Flood Mitigation Policy and Planning ---------------------------------- 30

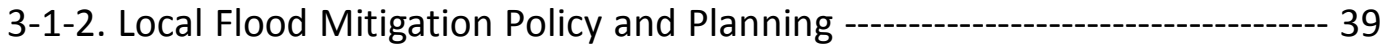

3-2. Flood Vulnerability Assessment -------------------------------------------------------------- 47

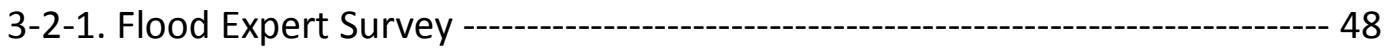

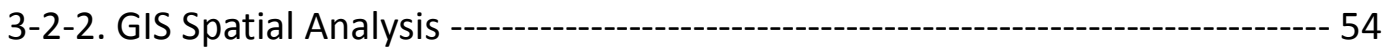


1) Methodology -------- 54

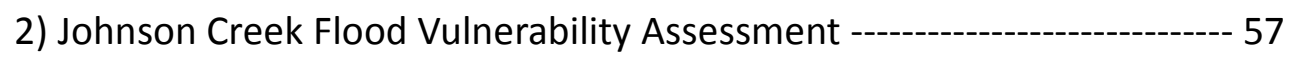

3-3. Comparative Analysis of Perceptions on Flood Risk and Environmental Justice - 67

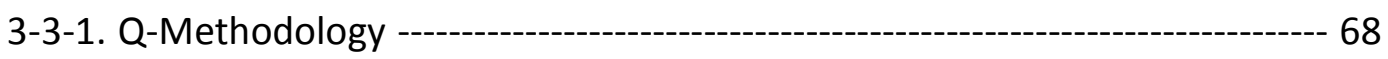

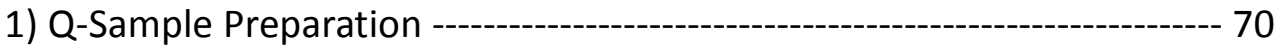

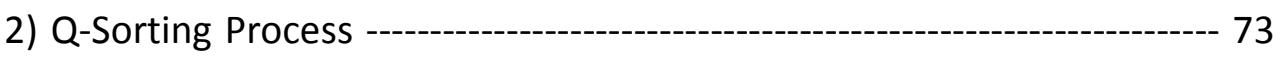

3) Q-Factor Analysis -----------o---o- 76

4. Discussion: Human Vulnerability and Human Rights in Natural Disaster Mitigation -- 93

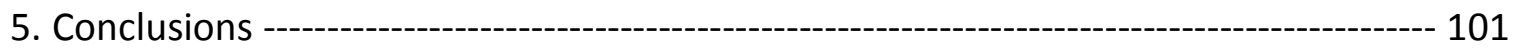

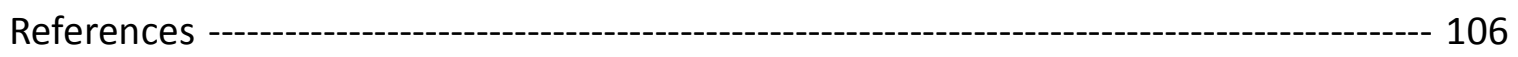

Appendix A: Johnson Creek Flood Expert Survey -------------------------------------- 112

Appendix B-1: Johnson Creek Physical Flood Vulnerability Results ----------------- 121

Appendix B-2: Johnson Creek Socioeconomic Flood Vulnerability Results ------------- 124

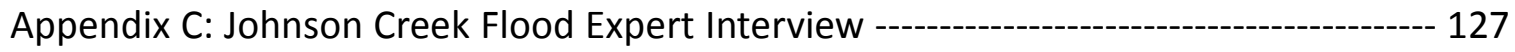




\section{List of Tables}

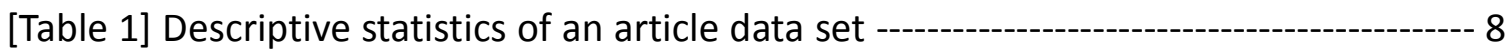

[Table 2] Differences between needs-based and human rights-based approaches ------ 24

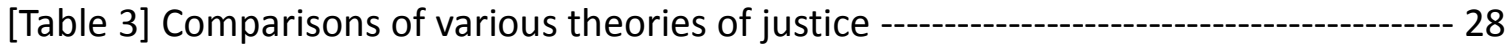

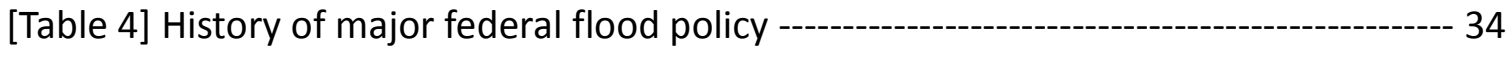

[Table 5] Credit points awarded for Community Rating System activities -------------------- 43

[Table 6] Johnson Creek flood vulnerability indicators rated by flood experts ------------- 53

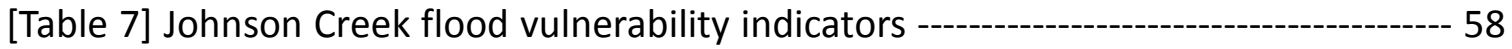

[Table 8] Main topics and related discussions for the formulation of Q-sample ---------- 71

[Table 9] Final Q-sample used for flood expert interviews ------------------------------------ 72

[Table 10] Overview of interview participants ------------------------------------------------- 75

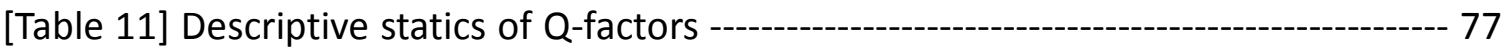

[Table 12] Participants loading on factors after varimax rotation ----------------------------- 78

[Table 13] Strongly agree and strongly disagree statements for Factor 1 ------------------- 80

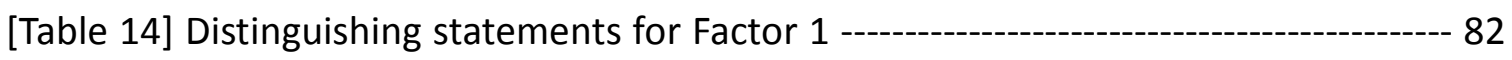

[Table 15] Strongly agree and strongly disagree statements for Factor 2 -------------------- 84

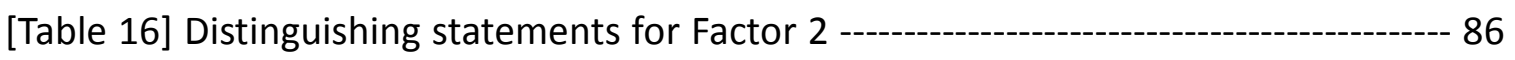

[Table 17] Strongly agree and strongly disagree statements for Factor 3 -------------------- 87

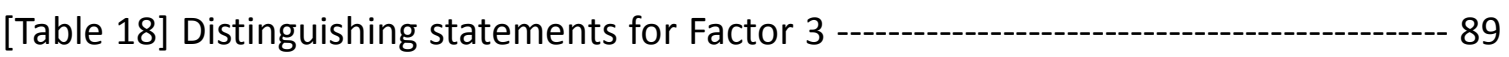

[Table 19] Consensus statements that do not distinguish between any pair of factors - 90 


\section{Lists of Figures}

[Figure 1] Percentage of journal articles on different aspects of flood vulnerability ----- 12

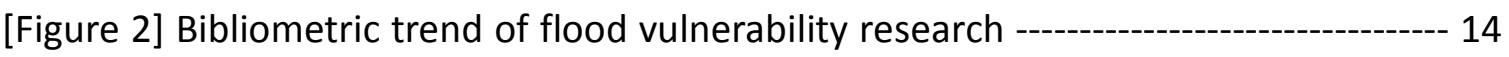

[Figure 3] Case study area map of Johnson Creek watershed ------------------------------ 39

[Figure 4] High flood risk areas along Johnson Creek identified by flood experts -------- 50

[Figure 5] Process of GIS-based flood vulnerability assessment ------------------------------- 56

[Figure 6] Physical flood vulnerability score map ------------------------------------------------- 60

[Figure 7] Socioeconomic flood vulnerability score map ------------------------------------- 61

[Figure 8] Integrated flood vulnerability score map --------------------------------------------- 63

[Figure 9] Flood vulnerability scores of each census block group ----------------------------- 64

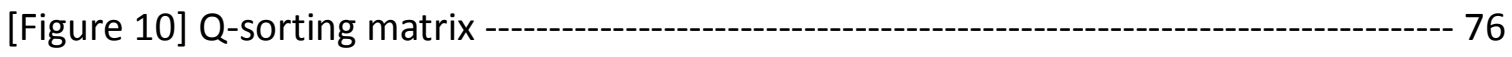




\section{Introduction: Socialization of Natural Disaster Problems}

"Until society can be reclaimed by an undivided humanity that will use its collective wisdom, cultural achievements, technological innovations, scientific knowledge, and innate creativity for its own benefit and for that of the natural world, all ecological problems will have their roots in social problems".

Murray Bookchin, 1989

Natural disasters are increasing around the world disrupting the prosperity, safety, and amenity of human settlements. According to the U.S. National Oceanic and Atmospheric Administration (NOAA), the U.S. has sustained 218 catastrophic weather and climate disasters from 1980 to 2017 , and the total cost of these events exceeds $\$ 1.2$ trillion. ${ }^{1}$ As one of the most common and widely distributed natural disasters, floods, in particular, are increasing in both frequency and intensity, every year. Based on the National Weather Service (NWS) flood data from 1926 to 2001, the cost of floods has been annually increased at a rate of $3.45 \%$ in the U.S. (Cartwright, 2005).

Similar to other natural disasters, flood risk represents the probability of negative consequences due to floods and emerges from the convolution of flood hazard and flood vulnerability (Schanze et al., 2006). Along with measuring predicted flood hazards $^{2}$ (the external risk factor), evaluating current vulnerability (the internal risk

1 Only catastrophic disasters - disasters costing in excess of \$1billion (including CPI adjustment to 2017) were counted, and the total does not yet include the costs for Hurricanes Harvey, Irma, and Maria that happened from August to October 2017.

2 In general, a hazard represents a situation that poses a level of threat to life, health, property or environment, and disasters are seen as the consequence of inappropriately managed risk. From this 
factor) in this respect has been considered a significant and urgent topic in various disciplines of disaster management. Until now, however, flood mitigation ${ }^{3}$ practices have been dominated by a concern about the physical aspect of floods - external threats to the built environment and related economic losses. Most efforts have been focused on preventing flood risks by constructing various kinds of structures (e.g., levees, floodwalls, dams, embankments, storage basin, diversions, etc.), and weighing costs and benefits as a primary means for selecting different flood protection standards and measures. Vojinović and Abbott (2012) criticized that these are appealing but simplistic ways of assessing the benefits of different measures even as other aspects, such as ethical consideration of impacts on society and the ecosystem, are completely left unattended. Globally, the focus of natural disaster mitigation is gradually changing from risk avoidance to 'living with risk' (UN/ISDR, 2004) based on the realization that natural disasters are a phenomenon which cannot be completely eliminated nor brought under total control. Recently, it is becoming more popular to adopt the concept of 'acceptable risk' rather than adopting preset levels of protection (Vojinović and Abbott, 2012), and therefore, understanding internal risk factors, including vulnerability, and providing

point of view, some scholars make the distinction between 'hazards' and 'disasters' noting that disasters are human-made due to the lack of human preparation.

3 There are four phases of natural disaster planning and emergency management - mitigation, preparedness, response and recovery. Federal Emergency Management Agency (FEMA) defines 'preparedness' as building plans or preparations to help response and rescue operations, 'response' as conducting operations to prevent further damage, and 'recovery' as taking action to return the community's systems and activities to normal. 'Mitigation' represents any sustained actions taken to reduce or eliminate long-term risk to people and property from hazards and their effect. In this study, 'mitigation' is used as a broader term that encompasses all actions to prepare for, respond to, and recover from a disaster or emergency. 
sustainable approaches to potentially alarming long-term consequences are becoming a significant first step in developing more holistic policies and strategies for natural disaster mitigation.

Especially in urban areas, natural disasters are perceived to be much more endogenous to society these days, because their impact depends crucially on socioeconomic factors that are potentially intensifying the vulnerability of individuals and communities. Not only as technical but also as social problems, natural disasters thus can be a matter of ideology, and essentially, manifestations of ethical and political conflict. From this point of view, the socialization of natural disaster problems has two significant meanings. First, it introduces a distinct perspective that understands natural disasters as the outcome of socioeconomic and public policy responses. In this new paradigm, it becomes important not only to develop techniques and tools for the evaluation of nature's physical hazards but also to focus on urban environmental changes by observing and analyzing social and institutional phenomena. Second, it raises fundamental questions about environmental justice. In our society, individuals have different needs and may require different supports depending on their abilities and social status. From an environmental justice perspective, the socialization of natural disaster problems means to focus on multiple aspects of disaster vulnerability and provide an opportunity to ensure fair and equitable disaster policy and strategies through protecting basic rights of socioeconomically vulnerable populations.

In order to address natural disasters as urgent social problems that urban 
communities are facing, it is necessary to ask first whether the system and institutions presently in place are paying attention to the socioeconomic aspects of disaster vulnerability and promoting environmental justice for disadvantaged and marginalized populations in the city. Hence, this study aims to explore the possibility of environmental justice as social consensus and an institutional framework to reduce differences in natural disaster vulnerability. In this study, the concept of environmental justice will be reframed as an opportunity 1) to understand individual differences in needs, abilities and interests in terms of natural disaster risks, and 2) to suggest that the urban society has institutional obligation to implement reasonable policies that would create solutions to socioeconomic inequality and human rights problems.

This study begins in chapter 2 with a discussion on various aspects of vulnerability and theories of justice to clarify the meaning of environmental justice in the context of natural disaster mitigation. Chapter 3 reports on three different analyses conducted to address the issues of flood risk and environmental justice in Johnson Creek, Portland, Oregon as a case study. First, institutions and policy analysis was used to investigate how federal and local governments are addressing and responding to current flood problems. By analyzing institutions, policies, and currently ongoing flood mitigation projects, the first analysis mainly focused on whether the federal and local efforts are in accordance with the principles of environmental justice. Second, through flood expert surveys and GIS spatial analysis, flood vulnerability assessment was conducted as a way to understand various factors that contribute to communities' 
susceptibility to flood risks. By doing so, this study attempted to obtain evidence on whether flood experts and urban practitioners are considering both physical and socioeconomic aspects of flood vulnerability, and how they are understanding root causes and contributing factors of current flood problems in the Johnson Creek area. Finally, this study used Q-methodology to explore the diverse range of meanings and understandings that flood experts and practitioners construct in relation to the dilemmas of environmental justice in flood mitigation practice. Through comparative analysis of perceptions, this study diagnosed the possibility of institutional blind spots and barriers in achieving environmental justice in natural disaster mitigation policy and planning. Chapter 4 then discusses the opportunities and challenges of human rights as a core component of environmental justice, and the human rights-based approach as a normative framework to address socioeconomic inequality problems in disaster mitigation. Finally, Chapter 5 concludes the study, restating the importance of environmental justice in natural disaster mitigation policy and planning with acknowledgement of this study's limitations as well as recommendations for further research. 


\section{Theoretical Background of Natural Disaster Mitigation}

Before starting a discussion on the meaning and implications of environmental justice in natural disaster mitigation policy and planning, consider first who vulnerable populations are and what makes them vulnerable to natural disasters. From a sociological perspective, it is important to understand that vulnerable populations do not choose to be vulnerable. In other words, these people suffer from involuntary physical and socioeconomic weaknesses that are beyond their ability to control or change. Second, vulnerable populations normally lack influence or power to express their difficulties and disadvantageous circumstances. A fully process-focused approach thus may lead to public policy that can favor those who are best placed to take advantage of governance institutions. Lastly, vulnerable populations are often discriminated despite the fulfillment of their social duties. Social discrimination in this respect can lead to further vulnerability that obstructs persons, groups and communities to participate in and contribute to various aspects of social, economic and political life.

Meanwhile, from a disaster prevention perspective, determining vulnerable populations becomes more complicated, requiring a thorough understanding of multiple aspects of disaster vulnerability and how they are interconnected with each other. Vulnerability is the result of the range of physical, social, economic, cultural, institutional and political factors that shape peoples' lives and environment (Twigg, 2004). Vulnerability can be a challenging concept to understand because a variety of relative terms such as disposition, fragility, weakness, deficiency or lack of capacity is often used 
to describe it. For this reason, this study conducted a comprehensive literature review to better understand the concept of vulnerability, which is critically important for developing further discussion on environmental justice and the proper role of natural disaster mitigation policy and planning.

\section{2-1. Natural Disaster and Vulnerability}

Vulnerability as a core concept of natural disaster mitigation provides an analytical tool for evaluating susceptibility to harm, powerlessness and marginality of both physical and social systems (Adger, 2006). Vulnerability does not exist in isolation from the wider social, economic, and political aspects of resource use and management in urban areas. From this point of view, the International Strategy for Disaster Reduction (UN/ISDR) defines vulnerability as the conditions determined by physical, social, economic, and environmental factors or processes, which increase the susceptibility of a community to the impact of hazards (UN/ISDR, 2004). Nonetheless, vulnerability has been defined in many ways, with only limited consensus on the meaning of the concept (Pandey and Bardsley, 2015). Most definitions share the understanding that vulnerability should be 1) understood as a comprehensive concept that includes multilateral aspects of exposure, sensitivity and adaptive capacity (Turner et al., 2003; Polsky et al., 2007; Cutter et al., 2008), and 2) assessed in a way to capture both 'direct impact' (exposure and susceptibility) and 'indirect impacts' (socioeconomic fragility and lack of resilience) (Birkmann, 2006). 
[Table 1] Descriptive statistics of an article data set

\begin{tabular}{l|c}
\hline Total selected articles & 318 \\
\hline \hline Years articles published & Jan 2006 - Dec 2016 \\
Number of journals included & 34 \\
Number of research areas & 839 \\
Number of author-identified keywords & \\
\hline
\end{tabular}

Systematic literature review on vulnerability using bibliometric analysis was conducted to examine the wide range of meanings and uses of the term. In order to narrow down the research scope, this study focused on urban floods - the most common and expensive global natural disaster, and examined flood vulnerability research during the last 10 years (from January 2006 to December 2016). Although the spatial scope of research was limited to urban or peri-urban area, this review considered both natural and climate change-induced floods and did not make an analytical distinction among research fields such as flood prevention, reduction, mitigation and resilience enhancement. The reason to limit the review to the articles published in the recent 10 years was that the study aimed to concentrate on the rapidly changing vulnerability research trend in the last decade since Adger (2006) - one of the most widely used and arguably the foremost research work on vulnerability. After examining a total of 318 peer-reviewed journal articles found from the Web of Science database using search topics of 'urban' and 'flood' and 'vulnerability', articles were classified into three major groups on the basis of their research focus on physical, socioeconomic and institutional vulnerability. 


\section{2-1-1. Physical Vulnerability}

Climate change and disaster research based on the risk-hazard (RH) framework sees vulnerability as a linear result of climate change impacts and aims at reducing the projected impacts through technological change and improvements (Füssel, 2007). In this framework, particular attention is given to the physical properties of the system that could suffer damage or harm due to an external phenomenon or to the idea that disaster could occur in the system due to the technology employed (Cardona, 2004). In general, various disciplines of applied science understand physical vulnerability as the degree of exposure and the fragility of the exposed element to disaster risks. Their socalled technological and engineering approach mainly focuses on probabilistic modeling to predict areas of hazards and estimate related physical damage of structure and infrastructure. In flood vulnerability research, as primary external risk factors, the approach of applied science extensively investigates natural causes of floods such as heavy rainfall, sea-level rise, storm surges, increasing groundwater levels and their combinations thereof. As a secondary cause, this approach also concerns technology and engineering related causes such as inefficient drainage systems, problems of evacuation routes and traffic, and the lack of proper flood defense structures.

\section{2-1-2. Socioeconomic Vulnerability}

The complexity of urban system - the variability of social relations and unique characteristics of community makes it difficult to assess the level of exposure and sensitivity of people and places to disaster risks. The pressure and release (PAR) 
framework in this respect sees disaster as the intersection between socioeconomic pressure and physical exposure. This framework shares a viewpoint with a social constructivism which attempts to understand vulnerability as an attribute of social and ecological systems that are generated by multiple factors and processes in urban society (Eriksen and Kelly, 2007). Vulnerability in this framework is obtained from identifying unsafe conditions such as social fragility owing to economic weakness, marginality and social segregation (Cardona, 2004). Due to this reason, the approach of social science mainly focuses on people and their socioeconomic relationship to societies and pays attention to the value of equity, social and environmental justice and human rights more than scientific reasoning. By placing the burden of explanation of vulnerability within the social system, disciplines of social science concentrate on the socioeconomic aspect of vulnerability to explain why different communities can experience the same hazard event differently (Morrow, 2008), and to suggest more effective disaster mitigation strategies for people who are less likely to have access to resources during disaster events (Yoon, 2012). This approach is valuable to understand not only group differences but also how those groups experience and perceive natural disasters differently depending on the social infrastructure and living conditions they confronted.

\section{2-1-3. Institutional Vulnerability}

According to the access model, risk is associated with the ability of people to deal with the impact of the hazards they face in terms of what level of access they have to the resources needed for their livelihoods (Wisner et al., 2003). This argument is 
based on the fact that when facing an equivalent hazard, risk could be different depending upon the capacity to absorb the impact (Cardona, 2004). For this reason, as a way to evaluate the coping ability of the city, the institutional aspect of disaster vulnerability has been researched by disciplines such as urban studies, public administration and political science. In general, institutional vulnerability is defined as the exposure and vulnerability of individuals, communities or organizations to the uncontrollable adverse consequences of another organization's critical shortcomings (Parker and Tapsell, 2009). In the domain of disaster management, as a mirror that reflects the stability, efficiency and responsiveness of government agencies and organizations, institutional vulnerability is understood as the incapacity or limited capacity of urban systems in resolving a mismatch between understanding, knowledge, economic costs, and levels of trust during the disaster management process.

Distinguishing institutional vulnerability separately from socioeconomic vulnerability is important because 1) once natural disasters are perceived and publicized as a social problem, the process of envisioning possible solutions is conducted in different socio-political domains, and 2) the failure of public policy and planning practice can create and institutional 'blind spot' toward a particular group (or groups) of people which ignore the contextual experience of risk and consequently increase their socioeconomic vulnerability. From this point of view, Innes and Booher (2010) emphasized that collaborative process of decision-making brings a diversity of private and public stakeholders together in a consensus-oriented forum. Research focusing on 
institutional vulnerability recognizes the practice of collaborative decision-making as the process of shared learning and cooperation and attempt to understand multiple sociopolitical interactions through the lens of governance - the collective institutional and policy response to urban problems. Addressing structural, organizational and systematic challenges to effective urban governance, institutional vulnerability research gives considerable emphasis on the practical lessons of communication across the system boundaries that can be learned from interdisciplinary collaboration and participatory decision-making.

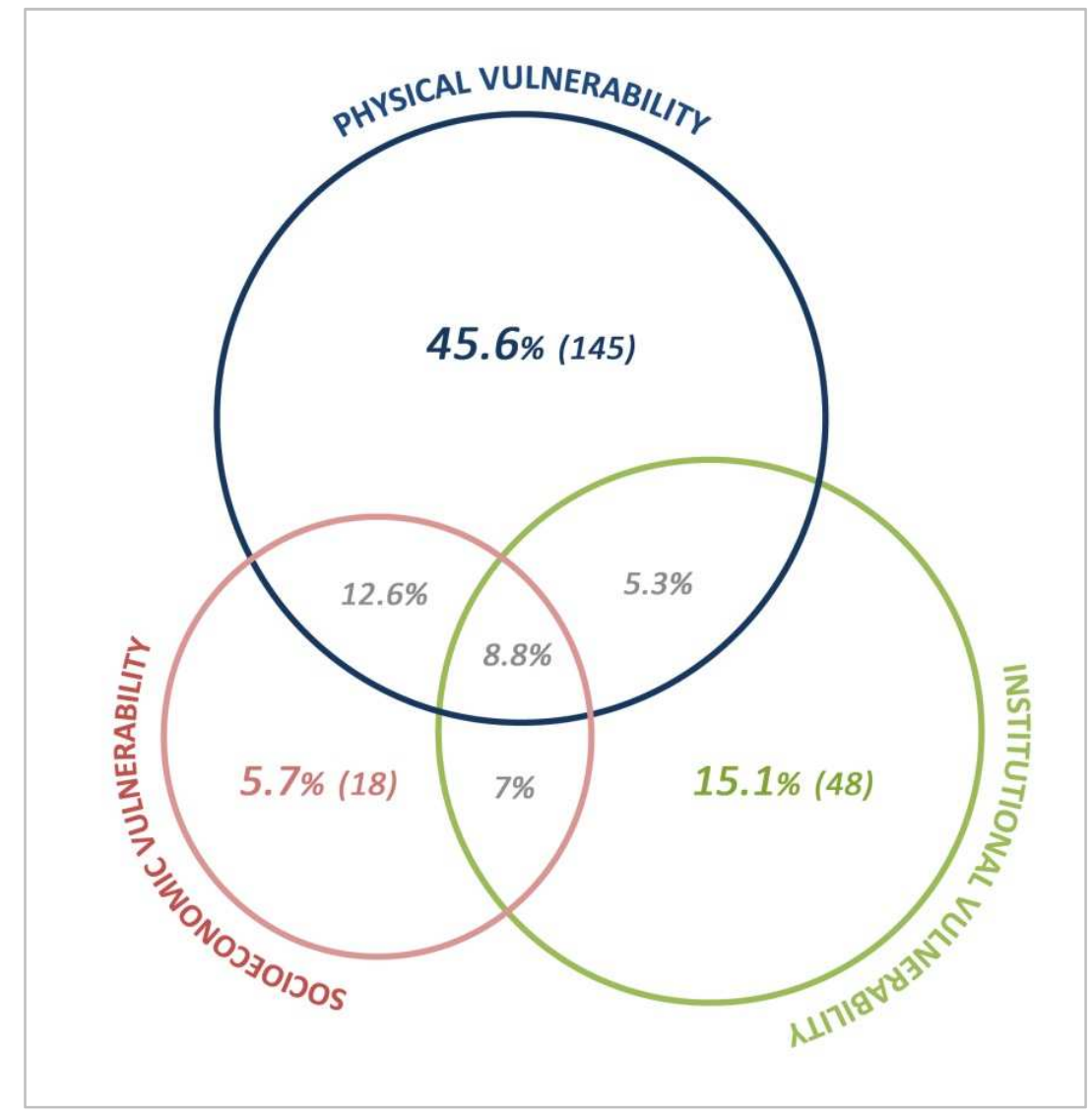

[Figure 1] Percentage of journal articles on different aspects of flood vulnerability 
As shown in Figure 1, physical vulnerability was the most popular research concern $(45.6 \%)$, followed by institutional vulnerability (15.1\%) and socioeconomic vulnerability (5.7\%). More than one-third of total research articles discussed the multiaspects of flood vulnerability. The combination of physical and socioeconomic vulnerability was the first with $12.6 \%$, and the combination of all three aspects of vulnerability was the second with $8.8 \%$. Even though nearly half of the selected articles focused on the physical vulnerability, it was noticed that institutional vulnerability research has the potential to link physical and socioeconomic aspects of flood vulnerability leading the collaboration between disciplines of applied science and social science. Most of institutional vulnerability research reviewed in this study mainly discussed about collaborative flood governance as a way to enhance urban resilience and an opportunity to advance interdisciplinary understanding of urban floods not only as a natural phenomenon but also as a social problem shaped by political, economic and cultural conditions. 


\section{2-1-4. Human Vulnerability}

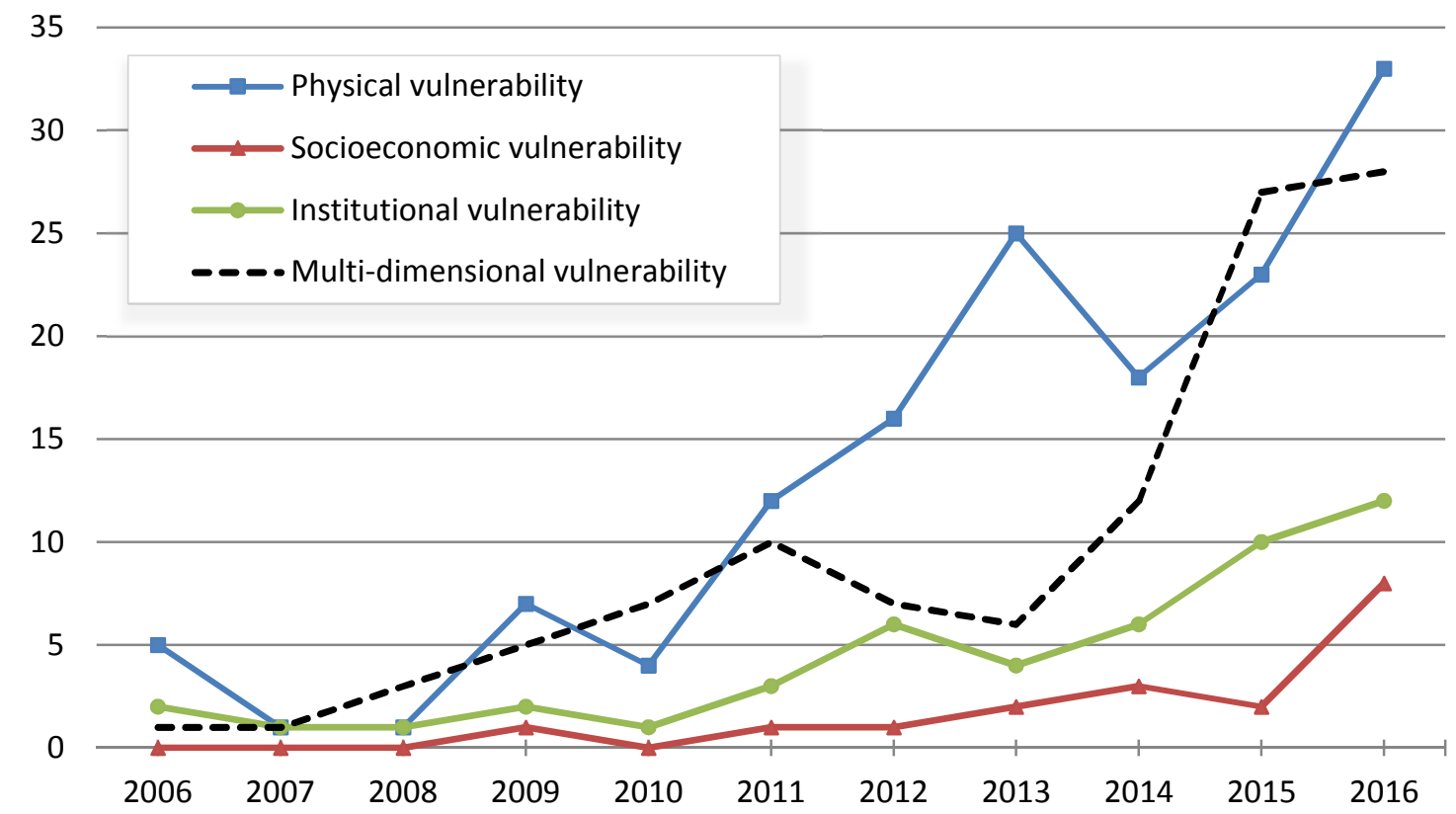

[Figure 2] Bibliometric trend of flood vulnerability research

Figure 2 shows that an increasing number of articles employ a holistic approach in order to understand multiple aspects of flood vulnerability. Within the last 10 years, this effort has expanded the scope of flood vulnerability research to the socioeconomic domain and enabled researchers to discuss various normative and ethical issues such as environmental justice, human rights, and the proper role of natural disaster policy and planning. The holistic approach to flood vulnerability research in this respect is expected to provide an opportunity for researchers, engineers, practitioners and decision makers to understand vulnerability in the diverse contexts of social characteristics, economic status, and political power of people, groups and communities.

For this reason, this study emphasizes the need to integrate various aspects of 
vulnerability with the broader concept of 'human vulnerability' - a new comprehensive tool to understand not only physical impact but also various socioeconomic and institutional problems that can be caused by the collapse of social norms and values. The term human vulnerability in this respect represents the interface between exposure to the physical threats to human well-being and the capacity of people and community to cope with those threats (UNEP, 2002). Human vulnerability is important because it is increasingly recognized that the human-environmental system through which humans interact with their environment should be approached in an integrated manner (Birkmann, 2006). The concept concerns both physical and socioeconomic aspects of vulnerability, and links the relationship people have with their environment to social forces and institutions that sustain or contest them (Paul, 2011). From an environmental sociology perspective, human vulnerability thus becomes a key to resolve social consequences of natural disasters.

Obviously, disaster vulnerability is unequally distributed across various social attributes. Relatively more vulnerable populations (the poorer segment of society, women, children, elderly, and disabled) usually have the most limited choice in dealing with natural disaster risks. Efforts to reduce human vulnerability thus can be considered a matter of achieving individual human rights by alleviating social exclusion and environmental injustice in our society. This means that human vulnerability can be reduced by transforming underlying social and political structures that contribute to the perpetuation of human exposure to natural hazards (Heijmans, 2004). From this point of 
view, this study uses human vulnerability as an integrated analytical device to understand the underexamined causes and consequences of natural disasters, and focuses on environmental justice as a theoretical framework to discuss social and institutional responsibility for promoting the human rights of those affected by natural disasters.

\section{2-2. Natural Disaster and Environmental Justice}

Vulnerability defines our humanity and is the common basis of human rights (Turner, 2006). Thus, if we agree that human rights are a response to human vulnerability, serious vulnerability can be considered as a rights deprivation (Kosko, 2013). The notion of human vulnerability in this respect represents a significant step change that allows urban communities to see a natural disaster as a matter of environmental justice - the institutional and ethical foundation that enables a holistic understanding of disaster vulnerability and ensures fair and humane solutions to protect the needs and rights of relatively more vulnerable populations.

Environmental justice is the social justice expression of environmental ethics. Therefore, environmental justice can be approached through the understanding of social justice and its meaning and importance in relation to environmental discourse and practice. Environmental justice as a means to reduce human vulnerability is difficult to grasp because the concept of justice is complex and can be interpreted differently by different political system, culture, history and public beliefs. Although the term often covers 'the relative distribution of rights, opportunities and resources within a given 
society, and whether it deserves to be regarded as fair and just' (Cramme \& Diamond, 2009), it means different things even to people with relatively similar backgrounds. Wenz (1988) asserted that many disputes are fostered by different conceptions of justice because a social arrangement or public policy that one person considers just may be considered unjust by another. In this section, this study thus explores major theories of social justice and examines their applicability and limitations to environmental justice from a natural disaster mitigation perspective.

\section{2-2-1. Libertarian Theory of Justice}

As it is well known, liberalism is one of the most central and pervasive political and economic ideologies of contemporary society. Originally, classical liberalism was started in $17^{\text {th }}$ century as a way to oppose absolute monarch and feudal system and to promote individual freedom in a general sense. Today, liberalism recognizes individual liberty as the highest moral goal and the essential component of a just society. Based on this ideological foundation, different theories of justice have been developed by political philosophers in order to find possible solutions to problems of inequality that are byproducts of capitalist society. Several scholars note that there are three primary theories of social ethics that have application to environmental justice - libertarianism, utilitarianism and egalitarianism (Wenz, 1988; Davy, 1997; Liu, 2001).

Firstly, as one of the most contentious theories, libertarianism emphasizes the liberty of individuals and prefers the invisible hand of the market rather than central command and control (Hartman and Spit, 2015). The core insight of this ethics is that 
the state should be small and neutral in order to protect individual freedom (Budd and Scoville, 2005). Robert Nozick, a renowned libertarian philosopher, asserted that the recognition of liberty rights should have the highest priority and nothing more than the maintenance of peace and security of individuals and property by the state can be justified (Nozick, 1974). The essence of Nozick's theory of justice is his defense of an individual against the society. According to his idea, Rawls's distributive theory of justice cannot be morally justified because whatever is to be distributed comes already tied to people (Phillips, 1986). His entitlement theory of justice is connected with Locke's possessive individualism ${ }^{4}$ which claims that the owner must be able to choose what to do with his or her property because otherwise the owner is not a free individual and therefore has no dignity. From a libertarian perspective, individual ownership is thus a key element of free and just society and egalitarian distribution is a violation of human rights.

Environmental justice, however, cannot be achieved by permitting all issues to be decided in a free market that is protected by a minimal state (Wenz, 1988). In practice, current environmental and natural disaster problems cannot be addressed with the libertarian theory of justice because 1) environmental goods such as clean air, fresh water and fertile soil are public goods that are not provided in a free market, and therefore, can cause the tragedy of the commons and the problem of externalities, and

4 Possessive individualism is the idea that everyone's normative essence consists in his or her ownership. According to Locke's theory of property, people own their labor, and the fruit of their labor should be rewarded with a property right. Strauss (1953) in this regard argued that Locke's idea is reflective of the individualism that leads to the spirit of capitalism. 
2) property rights often need to be limited and shaped by government action in order to mitigate uncontrollable and unpredictable disaster risks in a coherent and integrated manner. Today, a more active and responsible role of public policy is essential because identifying and balancing conflicting rights have become more urgent and necessary than ensuring the acquisition and transfer of individual rights. Environmental justice as normative justice in this respect should work as a useful tool to explore, question and reframe both internal tensions and external conflicts of society. For this, it is inevitable to increase institutional responsibility to foster ethical standards and value systems and provide fair and consistent policies for everyone.

\section{2-2-2. Utilitarian Theory of Justice}

Utilitarianism aims to achieve the greatest good for the greatest number of people. What makes utilitarianism different from libertarianism is the focus of good consequences for all stakeholders and not just the individual. According to Jeremy Bentham, individuals are rational maximizers of their own happiness, and therefore, desist from actions which can cause them more pain than pleasure (Mathis, 2009). For him, happiness was a mathematical equation simply quantifiable by subtracting our pain from our pleasure (Keen, 2012). In this sense, the happiness of a community as a whole is composed of the sum of individual pleasures, and so moral obligation is to perform efficient action which will produce more amounts of pleasures for the greater number of people. 
From an environmental standpoint, utilitarian justice seems to tolerate environmental destruction and natural resource exploitation if it creates more utility for many people. Actually, there are several successful examples of laws and policies emerged from the utilitarian ethics that shifted burden from those threatened by environmental harm to those who caused it through an exercise of their property rights (e.g., The Clean Air Act of 1970, The Clean Water Act of 1972). However, it is difficult to deny that the utilitarian way of thinking is largely based on quantitative measurement and prediction in order to choose a good course of action. Even though 'good' is difficult to quantify, utilitarian justice tends to make decision by monetizing the value of good and simply comparing costs of actions with benefits. The utilitarian theory of justice in this respect can cause morally deficient actions because it permits us to be short-sighted and calculating to bring about good consequences and, more importantly, it justifies the sacrifice of the minority for the benefit of the majority.

As Rawls (1979) mentioned, the problem of utilitarian interpretation of justice is to adopt 'for society as a whole the principle of rational choice for one man', to combine the desires of all persons into one coherent system of desire and to seek its overall satisfaction. By doing so, it fuses or conflates all persons into one, and reduces social choice to essentially a question of efficient administration (Sandel, 1982). Certainly, utilitarian justice raises fundamental questions about personal integrity and human rights so it cannot be used as the sole criterion of environmental justice (Wenz, 1988). In the domain of natural disaster mitigation, if only the greater happiness of the majority is 
emphasized, ignoring the needs and rights of underrepresented populations, adaptive actions for potential disaster risks can reduce the vulnerability of only those best placed to take advantage of governance institutions. Environmental justice as commensal justice in this respect should aim at rebuilding confidence and mutual trust among social constituents through the acknowledgement of the humanity of others. For this, it is important to understand how differently groups of people can experience and perceive the same situation differently due to inherent vulnerabilities they face.

\section{2-2-3. Egalitarian Theory of Justice}

A common objection to utilitarianism concerns its insensitivity to considerations of justice (Wenz, 1988). As the ethics of free-market economics, utilitarianism overlooks a notion of inviolable natural rights that everyone has, and by doing so, it neglects the individual (Garner, 2017) and a 'distributive' dimension of sound social morality (Becker and Becker, 2001). In this regard, egalitarianism focuses on societal level of justice that can offer a more morally appealing alternative than which the libertarian and utilitarian theories of justice can offer.

A leading $20^{\text {th }}$ century egalitarian theorist, John Rawls contended that we should act as if we are behind a 'veil of ignorance' so that we cannot choose principles of justice that favor our individual interests. The veil of ignorance, as a conceptual device to eliminate morally irrelevant information, forces people in the original position ${ }^{5}$ to focus

5 According to Rawls (1971), the 'original position' represents the conditions and constraints under which persons should deliberate about adequate principles of justice, and the most important part of the 
on the collective good rather than their own self-interests. Under this hypothetical situation, uncoerced, unanimous agreement on the principles of justice becomes entirely possible (Wenz, 1988). In order to achieve this moral agreement, Rawls argued that people in the original position will eventually settle on two basic governing principles. The first principle (the principle of equal liberty) states that each person has an equal right to the most extensive basic liberty compatible with a similar liberty for others. The second principle (the difference principle) states that any inequalities in the distribution of primary social goods (e.g., liberties, rights, opportunities, income and wealth) must be 1) to the greatest expected benefit of the least advantaged members of society and 2) open to all under conditions of fair equality of opportunity (Rawls, 1971). Based on these principles of egalitarian justice, Rawls rejects the libertarian interpretation of justice because it fails to concern how the major social institutions should distribute fundamental rights and duties in a consensual manner. Also, he criticizes the utilitarian way of conceiving justice because it fails to support for individual human rights especially for those who are more vulnerable to socioeconomic exclusion.

From a disaster mitigation point of view, the problem of Rawls's theory of justice is that it seems simply morally wrong not to provide humanitarian support to socioeconomically vulnerable populations. Egalitarian justice in this respect leads to the next question of how to understand institutional moral responsibility in order to encompass both procedural and consequential fairness. Under the paradigm of 
egalitarian justice, the scope of institutional responsibility has expanded to include providing basic assistance to socioeconomically vulnerable populations. In terms of institutional support, both needs-based and human rights-based approaches in this respect aim to understand each individual's ability to control or change the situation first. One of the most significant differences is that the basic needs approach does not imply the existence of a duty-bearer. When demands for meeting needs have no 'object', nobody has a clear-cut duty to meet needs, and rights are vulnerable to ongoing violation (Jonsson, 2003). Generally, basic needs are about charity or morality, and therefore, a needs-based approach is considered as charitable or benevolent actions. For this reason, as moral responsibility which is not owed to a specific individual at any particular time, reducing inequality for socioeconomically vulnerable populations is regarded as social dispensation, not obligation, and often neglected whenever 'doing things rights' (democratic proceduralism) is considered to be prior to 'doing right things' (egalitarian consequentialism) in society. Meanwhile, even though human rights are also needs-based claims, human rights are binding legal obligations, and therefore, the realization of human rights is perceived as social interest and commitment. Consequently, a human rights-based approach can be understood as the expansion of institutional responsibility from 'supporting needs' to 'protecting human rights' - a more active commitment to human rights of the socioeconomically marginalized populations. 
[Table 2] Differences between needs-based and human rights-based approaches

\begin{tabular}{|c|c|}
\hline Needs-based approach & Human rights-based approach \\
\hline Needs are associated with 'having' & Human rights are associated with 'being' \\
\hline Needs do not imply duties or obligations & $\begin{array}{l}\text { Human rights are enforceable and place an } \\
\text { obligation on the state for fulfillment }\end{array}$ \\
\hline $\begin{array}{l}\text { Needs are subjective and can vary from } \\
\text { person to person }\end{array}$ & $\begin{array}{l}\text { Human rights are universal and apply to } \\
\text { everyone at all times }\end{array}$ \\
\hline $\begin{array}{l}\text { Needs are fulfilled out of a sense of } \\
\text { benevolence of the provider }\end{array}$ & $\begin{array}{l}\text { Human rights are fulfilled because right } \\
\text { holders are entitled to them and not because } \\
\text { of goodwill of anyone concerned }\end{array}$ \\
\hline $\begin{array}{l}\text { Needs may be limited or reduced especially } \\
\text { in cases of resource crunch }\end{array}$ & $\begin{array}{l}\text { Human rights are not limited and reserved } \\
\text { for a few }\end{array}$ \\
\hline $\begin{array}{l}\text { Needs are felt whether they fulfilled or not; } \\
\text { Needs may or may not be met }\end{array}$ & $\begin{array}{l}\text { Human rights are inherent but have to be } \\
\text { recognized through law or policy before they } \\
\text { are attainable }\end{array}$ \\
\hline $\begin{array}{l}\text { There are no consequences to the provider if } \\
\text { needs are not met; There is no accountability }\end{array}$ & $\begin{array}{l}\text { There are consequences if rights are violated; } \\
\text { There are mechanisms and remedies for } \\
\text { claiming human rights }\end{array}$ \\
\hline $\begin{array}{l}\text { People whose needs are being addressed } \\
\text { may or may not participate in the process }\end{array}$ & $\begin{array}{l}\text { Human rights require a participatory process } \\
\text { of the people in question }\end{array}$ \\
\hline $\begin{array}{l}\text { The non-fulfillment of needs becomes critical } \\
\text { only when a large section of people are } \\
\text { affected }\end{array}$ & $\begin{array}{l}\text { The violation of human rights of even one } \\
\text { individual is wrong }\end{array}$ \\
\hline Needs are negotiable & Human rights are non-negotiable \\
\hline
\end{tabular}

Source: Jonsson, 2003; Boesen and Martin, 2007; UNFPA, 2010

A human rights approach can supplement the practical limits of the egalitarian justice process by giving priority to understanding the particularity and difference among people and regarding human dignity as universal and unchanging moral principles that need to be promoted in any social and environmental context. Arguably, in natural disaster mitigation, environmental justice needs to be crafted in order to 
understand human vulnerability as a phenomenon ${ }^{6}$ and to achieve social consensus on protecting human rights of socioeconomically vulnerable populations. Revisiting justice using a human rights-based approach in this respect has significant benefits. It allows us to conceptualize environmental justice as more than a question of distribution and to account for the characteristic of the institutional framework for the successful implementation of human rights (Banerjee, 2018).

\section{2-2-4. Alternative Theory of Justice}

As seen above, the core value of justice has been changed from individual freedom and the enhancement of utility to the fair distribution of social goods. Each theory of justice has contributed to our understanding of the changing relationship between individual and society. However, as Wenz (1988) mentioned, there seems no single master principle or idea which can be elaborated to produce an adequate theory of environmental justice. In the context of natural disaster mitigation, the limitations can be summarized as 1) the lack of understanding of the particularity and difference of people, and 2) the indifference to institutional moral responsibility, which is essential to protecting individual human rights. From this point of view, this study examines some pluralist conceptions as alternatives to liberal theories of justice.

${ }^{6}$ According to Husserl, a phenomenon is what appears in our consciousness when we experience something as something. All that appears to us in one way or another has to be taken into account and everything else has to be disregarded at the beginning of speculation. Human vulnerability as a phenomenon enables us to look at disaster risk as a whole and leads to the essence of the problem the value of human life and the necessity to give care and protection to vulnerable people. 
Iris Young, an influential contemporary political theorist, criticized liberal theories of justice for focusing on the allocation of material goods and neglecting inequalities that stem from social relations. According to Young (1990), there are two social conditions which define injustice - the institutional constraints on selfdevelopment (oppression) and the institutional constraints on self-determination (domination). Justice of difference ultimately aims to challenge both oppression and domination encouraging democratic inclusion and cultural recognition (Squires, 2013). To be truly inclusive, Young emphasizes a notion of 'communicative democracy' that appreciates diversity, multiplicity and particularity, and treats difference as a resource rather than as something to overcome. Young's theory of difference seems highly applicable to environmental and natural disaster issues because it concerns the institutional mechanism for promoting greater inclusion of underrepresented groups in society. By recognizing all forms of diversity among humans and sociocultural conditions that influence participation in everyday life, justice of difference enables us to practice equality through the decision-making process and determine 'what there is to distribute, how it gets distributed, who distributes and what the distributive outcome is' (Young, 1990). Justice of difference is indeed closely connected with the notion of human rightsbased approach that aims to enhance capacity of both rights holders and duty bearers.

Secondly, communitarian theorists such as Michael Walzer, Alasdair Maclntyre, and Michael Sandel deny universal moral principles and focus on shared values and cultural traditions as a prerequisite of a well-functioning society. According to Walzer 
(1983), different social goods need to be distributed for different reason and according to different criteria which are derived from the different understandings of the social goods themselves. Through the concept of 'complex equality', Walzer argued that every social 'sphere' should have its own appropriate distributive principles, and injustice occurs when the distribution of one good can become dominant in other spheres of distribution. The communitarian notion of justice has two significant meanings in the context of natural disaster mitigation. First, it raises a question of what is the social meaning of natural disaster mitigation as a sphere of justice. As addressed throughout this section, the social meaning of natural disaster mitigation lies in promoting and protecting human rights - the positive rights to be protected and supported against unpredictable and catastrophic disasters. If this can be understood and shared as communal agreement by the members of society, the next question will be how to achieve this principle of environmental justice in natural disaster mitigation. To answer this question, this study suggests that we need to expand the theory of environmental justice from liberalism to critical pluralism that encourages altruistic, inclusive and flexible governance mechanisms. Arguably, from a critical pluralist perspective, the principle of environmental justice in natural disaster mitigation should be aligned to the aims of human rights-based approach in a way to consider individual differences in needs and abilities, and encourage institutional responsibility to support socioeconomically vulnerable populations. 
[Table 3] Comparisons of various theories of justice

\begin{tabular}{|c|c|c|c|c|c|c|}
\hline & $\begin{array}{l}\text { Libertarian } \\
\text { justice }\end{array}$ & $\begin{array}{l}\text { Utilitarian } \\
\text { justice }\end{array}$ & $\begin{array}{l}\text { Egalitarian } \\
\text { justice }\end{array}$ & $\begin{array}{l}\text { Justice of } \\
\text { difference }\end{array}$ & $\begin{array}{l}\text { Communitarian } \\
\text { justice }\end{array}$ & $\begin{array}{l}\text { Environmental justice } \\
\text { in natural disaster mitigation }\end{array}$ \\
\hline $\begin{array}{l}\text { Major } \\
\text { theorists }\end{array}$ & $\begin{array}{l}\text { Adam Smith } \\
\text { Friedrich Hayek } \\
\text { Robert Nozick }\end{array}$ & $\begin{array}{l}\text { Jeremy Bentham } \\
\text { John Stuart Mill }\end{array}$ & John Rawls & Iris Young & $\begin{array}{l}\text { Michael Walzer } \\
\text { Alasdair MacIntyre } \\
\text { Michael Sandel }\end{array}$ & - \\
\hline Principle & Individual liberty & $\begin{array}{l}\text { The greater } \\
\text { happiness for the } \\
\text { greater people }\end{array}$ & Fair distribution & $\begin{array}{l}\text { Self-development } \\
\text { Self-determination }\end{array}$ & $\begin{array}{l}\text { Shared understanding } \\
\text { of community }\end{array}$ & $\begin{array}{l}\text { Promotion of } \\
\text { human rights }\end{array}$ \\
\hline $\begin{array}{l}\text { Theoretical } \\
\text { basis }\end{array}$ & $\begin{array}{l}\text { Possessive } \\
\text { individualism }\end{array}$ & Utility of actions & $\begin{array}{l}\text { Original position } \\
\text { Veil of ignorance }\end{array}$ & $\begin{array}{l}\text { Discourse of } \\
\text { difference }\end{array}$ & Complex equality & Human vulnerability \\
\hline Object & The strong & The most & The poor & The oppressed & The weak & The vulnerable \\
\hline State & Small state & Police state & Welfare state & Participatory state & $\begin{array}{c}\text { Decentralized } \\
\text { democratic state }\end{array}$ & Responsible state \\
\hline $\begin{array}{l}\text { Cause of } \\
\text { injustice }\end{array}$ & $\begin{array}{c}\text { Violation of } \\
\text { Individual rights }\end{array}$ & Inefficiency & Inequality & $\begin{array}{l}\text { Oppression and } \\
\text { domination }\end{array}$ & $\begin{array}{c}\text { Domination and } \\
\text { tyranny }\end{array}$ & $\begin{array}{l}\text { Difference in } \\
\text { vulnerability }\end{array}$ \\
\hline
\end{tabular}




\section{Case Study: Flood Risk Management in Johnson Creek, Portland, Oregon}

Preceding chapters established that 1 ) there are multiple aspects of vulnerability that can be experienced and perceived differently depending on the socio-political infrastructure and living conditions confronted by people, 2) urban society has responsibility to implement reasonable policies that would create solutions to reduce human vulnerability to natural disaster risks, and 3) human rights as a moral language has the potential to fill the ethical void in environmental justice discourses. Based on this reasoning, this study investigates how environmental justice can be implemented and promoted in actual natural disaster mitigation policy and planning.

This study focuses on the case of flood risk management in Johnson Creek, Portland, Oregon specifically. Even though concerns and worries about Johnson Creek floods have continuously increased in the City of Portland during last few decades, minimal research has been undertaken to understand whether the notion of environmental justice is being properly addressed by institutional and policy efforts to mitigate flood risks. As one of the most sustainable and human-centered cities in the U.S., one might expect the City of Portland to realize more equitable and responsible decision-making and governance practices by discussing environmental justice issues that are associated with Johnson Creek floods.

In this chapter, institutions and policy analysis was conducted to examine federal and local efforts in response to flood risk and environmental justice issues. Next, 
indicator-based flood vulnerability assessment was conducted to investigate current vulnerability situations and risk factors that communities and neighborhoods are facing. Lastly, Q-methodology was used to explore a wide range of environmental justice discourses framed by flood experts and urban practitioners, and to illustrate to what extent they have shared goals and values of environmental justice in addressing socioeconomic inequality problems in flood risk management.

\section{3-1. Institutions and Policy Analysis}

Public policy is not only the fruit of a rational and efficient management of public interests but also the product of politics and ideology. Accordingly, public policy becomes a mirror that reflects the ethical and political values and the level of consciousness of society. From this point of view, this study focuses on institutional aspects of flood mitigation and aims to investigate how the policy and regulatory framework has emerged and developed in accordance with the goals of environmental justice.

\section{3-1-1. Federal Flood Mitigation Policy and Planning}

Prior to investigating Portland's policy efforts to reduce flood risks, it is necessary to understand federal institutions and policies because they set national standards to be followed by regional and local governments. For this, this study reviewed U.S. federal flood policies enacted between 1930s and 2010s. ${ }^{7}$ The Flood

\footnotetext{
7 The reason for choosing this time frame is that there was no comprehensive legislation covering flood relief prior to the Federal Control Act of 1936.
} 
Control Act of 1936 was the first federal flood policy that recognized flood control as a federal responsibility and authorized the construction of public works projects in the interest of protecting private property (Kahrl, 2014). The Act authorized the construction of various structural flood control measures such as dams, levees, and dikes through the U.S. Army Corps of Engineers and other federal agencies. At the time, the Works Progress Administration (WPA) conducted various improvement and restoration works in rivers and streams as part of President Roosevelt's New Deal program. WPA's construction projects seemed to have limited success in reducing flood risks because flood structures have changed the natural characteristics of watershed, and consequently, caused more frequent flooding in many areas.

In the mid-1960s, flood policy entered a new phase as it was widely acknowledged that flood risks cannot be completely eliminated through structural measures. In order to achieve more comprehensive flood control, the U.S. government established the Water Resource Council for centralized water management and expanded policy assistance to include land use planning and emergency response for communities. As flood disaster costs were greatly increasing, the federal government started to focus on the National Flood Insurance Program (NFIP) in the late 1960s. Initially, the program was intended to require states and local governments to adopt and enforce meaningful restrictions over new construction and reconstruction in floodplains (Platt, 1999). By purchasing flood insurance, people who insisted on building or living in high-risk area would pay at least part of the costs and they would recover more quickly 
from flood damage with the funds provided by the insurance program (ASFPM, 2015). In the 1970s, the purchase of flood insurance became mandatory for homeowners who obtained mortgage loans from federally regulated lenders. Later in 1977, the federal Executive Order on Floodplain Management (EO 11988) required all federal agencies to take action to reduce the impact of flood risks and to avoid the direct or indirect support of floodplain development whenever there was a practicable alternative.

In order to centralize emergency management functions at the federal level, the U.S. government created the Federal Emergency Management Agency (FEMA) in 1979 as the lead agency for disaster preparedness, response and relief. Through the Disaster Mitigation Act of 2000, FEMA's authority has expanded to make grants to state and local governments to assist in preparing for and responding to various types of natural disasters. For over 35 years, FEMA has contributed immensely in responding to natural disasters. However, much concern has been raised that many state and local governments cut funding to their own emergency management, thereby rendering themselves less prepared to handle natural disasters. From this point of view, Mayer and DeBosier (2010) pointed out that the 'federalization of disasters' misdirects vital resources, leaving localities, state and the federal government in a lose-lose situation. In order to let localities handle smaller and localized disasters, FEMA newly established the 'Whole Community' approach in an effort to incorporate the capabilities of the entire community and move beyond traditional, government-centric disaster management models (FEMA, 2011a). The concept of a whole community approach is a means by 
which residents, emergency management practitioners, organizational and community leaders, and government officials can collectively understand and address the needs of their respective communities and determine the best ways to organize and strengthen their assets, capacities, and interests (FEMA, 2011b). 
[Table 4] History of major federal flood policy

\begin{tabular}{|c|c|c|}
\hline Year & Policy & Remarks \\
\hline 1936 & Flood Control Act & $\begin{array}{l}\text { Authorized various structural flood control } \\
\text { measures through the U.S. Army Corps of } \\
\text { Engineers and other federal agencies. }\end{array}$ \\
\hline 1950 & Federal Disaster Relief Program & $\begin{array}{l}\text { Authorized the President to provide } \\
\text { supplementary assistance when a governor } \\
\text { requested help. }\end{array}$ \\
\hline 1965 & Water Resource Planning Act & $\begin{array}{l}\text { Established a Federal Water Resource Council } \\
\text { (WRC) to formulate more centralized water } \\
\text { resource projects. }\end{array}$ \\
\hline 1966 & Disaster Relief Act & $\begin{array}{l}\text { Expended federal disaster assistance to include } \\
\text { recovery for reestablishing communities after } \\
\text { disasters. }\end{array}$ \\
\hline 1968 & National Flood Insurance Act & $\begin{array}{l}\text { Created the Federal Insurance Administration } \\
\text { and made flood insurance available for the first } \\
\text { time. }\end{array}$ \\
\hline 1973 & Flood Disaster Protection Act & $\begin{array}{l}\text { Made the purchase of flood insurance } \\
\text { mandatory for the protection of property } \\
\text { located in special flood hazard areas. }\end{array}$ \\
\hline 1974 & Disaster Relief Act & $\begin{array}{l}\text { Established an orderly and continuing means of } \\
\text { federal assistance to state and local } \\
\text { governments which enables them to fulfill their } \\
\text { responsibilities to handle disasters and } \\
\text { emergencies. }\end{array}$ \\
\hline 1977 & Executive Order 11988 & $\begin{array}{l}\text { Directed federal agencies to avoid to the extent } \\
\text { possible the long and short-term adverse } \\
\text { impacts associated with the occupancy and } \\
\text { modification of floodplains. }\end{array}$ \\
\hline 1979 & Executive Order 12127 & $\begin{array}{l}\text { Formed Federal Emergency Management } \\
\text { Agency (FEMA) in order to coordinate the } \\
\text { response to a disaster that overwhelms the } \\
\text { resources of state and local authorities. }\end{array}$ \\
\hline 1988 & Stafford Act & $\begin{array}{l}\text { Encouraged states and local governments to } \\
\text { develop comprehensive disaster preparedness } \\
\text { plans and prepare for better intergovernmental } \\
\text { coordination in the face of a disaster. }\end{array}$ \\
\hline 2000 & $\begin{array}{c}\text { Disaster Mitigation Act } \\
\text { (Stafford Act amendments) }\end{array}$ & $\begin{array}{l}\text { Provided the legal basis for FEMA mitigation } \\
\text { planning requirements for state and local } \\
\text { governments as a condition of mitigation grant } \\
\text { assistance. }\end{array}$ \\
\hline 2013 & Disaster Relief Appropriations Act & $\begin{array}{l}\text { Provided about } \$ 50 \text { billion to federal agencies } \\
\text { for rebuilding communities after Hurricane } \\
\text { Sandy. }\end{array}$ \\
\hline
\end{tabular}


Clearly, the U.S. federal strategy for flood mitigation has constantly evolved supporting innovative projects that balance structural and nonstructural measures in an attempt to holistically address manifold challenges. While strengthening the federal leadership and support, the U.S. government has promoted financial efficiency and stability by encouraging local governments to take initiative in managing floodplains, and by requiring residents to purchase flood insurance for properties located in high flood risk areas. However, it is noticeable that most federal flood policies reviewed above do not touch upon socioeconomic consequences of floods and the related issues of environmental justice. Both structural and nonstructural measures have been mainly focused on reducing the physical aspect of flood vulnerability through technological and engineering solutions. Considering that flood insurance rates are continuously increasing each year and there are still low- and middle-income residents who cannot afford flood insurance, it is difficult to say that the NFIP reduces the socioeconomic aspects of flood vulnerability encouraging individual preparedness at the household level.

As seen through the case of Hurricane Katrina, many victims are poor, elderly, ill or disabled, and the social marginalization of these people often becomes a serious problem even during the process of federal assistance and recovery (Kamel, 2012). As Morse (2008) mentioned, minority and disempowered populations may be at great disadvantage in securing equitable policy decisions from elected and appointed official bodies through conventional processes because political power tends to be asymmetrical. In terms of natural disaster mitigation, it is thus important to bring 
environmental justice into the federal policy and regulatory framework in order to protect people from unequal harm due to their minority and income status.

Federal concern on environmental justice started from the environmental racism movement in the 1980s in reaction to discriminatory environmental practices including toxic dumping, municipal waste facility siting, and land use decisions that negatively affected communities of color. The National Law Journal Report in 1992 showed that there was stark disparity in enforcement of environmental laws between white and minority communities. It claimed that penalties imposed on violators of environmental regulations were much higher and cleanups were faster in white communities than in minority communities (Gorovitz Robertson, 2008). In order to reduce socioenvironmental conflicts at the federal level, the U.S. Environmental Protection Agency (EPA) established the Office of Environmental Justice (OEJ) in 1992, and started to provide technical and financial assistance to community-based organizations and local governments for environmental justice projects. In the following year, EPA established the National Environmental Justice Advisory Council (NEJAC) to obtain independent advice and recommendations from expert stakeholders outside the agency (Konisky, 2015). In 1994, as an important milestone in the environmental justice movement, Executive Order 12898 was issued to address environmental justice in minority and lowincome populations, and to reinforce Title VI of the Civil Rights Act of $1964^{8}$ (Miller et al.,

8 Title IV of the Civil Rights Act of 1964 was established to eliminate the historical barriers of segregation and discrimination based on race, color, and national origin. Title VI ensures that no person to be excluded from participation in, be denied the benefits of, or be subjected to discrimination under any 
2003). It was the first federal action that directed federal agencies to incorporate the principles of environmental justice into their missions. Under this order, federal agencies were required to develop an agency-wide environmental justice strategy, and to identify and address the environmental effects of their proposed programs on minorities and low-income communities.

Recently, EPA as a strong, independent agency has taken significant steps to incorporate environmental justice concerns. For example, EPA released 'EJSCREEN', a new environmental justice screening and mapping tool to the public in 2015. EJSCREEN is a geospatial platform that provides demographic and environmental information for the United States at the census block group level. As a pre-decisional screening tool, it enables users to better understand areas in need of increased environmental protection, health care access, housing, infrastructure improvement, community revitalization, and climate resilience (The White House, 2015). One thing to point out is that EJSCREEN is still limited by not incorporating various types of local and context-specific disaster information such as disaster vulnerability indicators and disaster risk maps (e.g., flood hazard map, inundation extent map and evacuation plan map). If EJSCREEN can be further improved to aggregate, analyze and visualize both physical and socioeconomic vulnerability data, it will be possible to address environmental justice more strategically and holistically in disaster mitigation practices.

program or activity receiving federal financial assistance (42 U.S.C. 2000d). 
As an another example, EPA issued the 'Guidance on Considering Environmental Justice during the Development of Regulatory Actions' in 2015 to provide rule-writers and decision-makers information on when to conduct an environmental justice assessment. A year later, EPA also released the 'EJ 2020 Action Agenda' to strengthen EPA's commitment to environmental justice and bring environmental justice into the EPA's overall practice through the five-year strategic plan. These works show EPA's continuous efforts to advance environmental justice by institutionalizing the idea as a central priority of the federal government. The question is whether and how these efforts can be expanded or reinforced to cope with floods and other natural disasters. As addressed in previous chapter, environmental justice, as an ethical challenge, requires institutional leadership to actively support human rights of underprivileged populations. In natural disaster mitigation, however, environmental justice is still a nebulous issue, and federal institutions and policies are insufficient to address multi-dimensional and context-specific disaster problems. Achieving environmental justice for low-income and minority communities is tantamount to preserving their fundamental rights (Killcreas, 2012), and it is thus essential for the federal government to develop clear standards and guides that define the role and responsibility of governmental institutions in addressing root causes of disaster vulnerability that underlie human rights violations. 


\section{3-1-2. Local Flood Mitigation Policy and Planning}

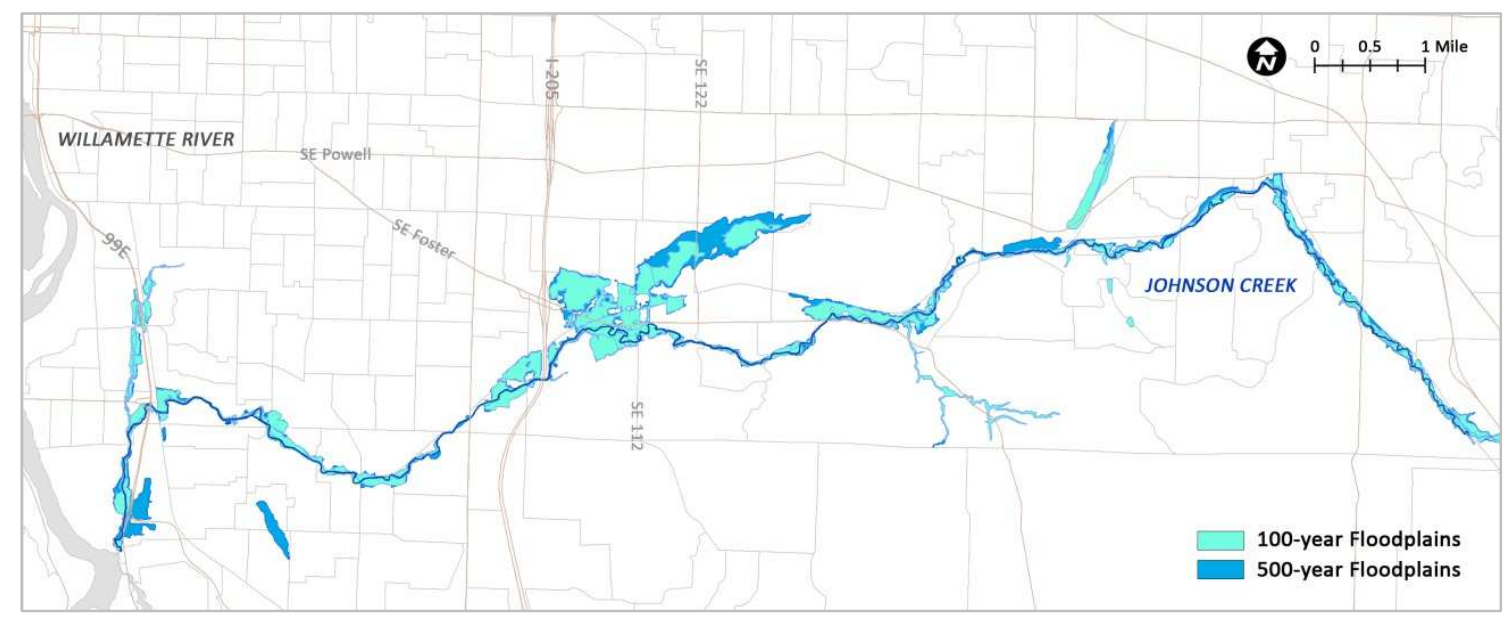

[Figure 3] Case study area map of Johnson Creek watershed

Johnson Creek is a small stream that flows 25 miles westward from its origins in the Cascade foothills to its convergence with the Willamette River. The natural history of Johnson Creek provides an example of how a natural disaster as a social problem contributed to the transformation of public policy and civic infrastructure. It seems that Johnson Creek floods started to be recognized as a serious issue since the 1800 s when pioneers began to settle in floodplains where land is fertile and water is abundant. By the early 1900s, the flood problem became more complex as urbanization replaced farms with houses and encouraged more and more people to build and live in Johnson Creek floodplains. According to Portland's Bureau of Environmental Services (BES), Johnson Creek has flooded 37 times since 1942, and local residents have experienced at least seven floods causing major property damage in the last 35 years. It is generally known that the situation was worsened by one of the most significant changes in the watershed occurred in 1930s when the Works Progress Administration (WPA) attempted 
to control flooding by making the creek wider and deeper and lining the creek with rocks (Bureau of Environmental Services, 2018a). These measures disconnected the creek from its natural floodplains substantially altering its historical condition, and consequently, induced more frequent floods in the area. Moreover, urbanization at this time also exacerbated the situation by creating more impervious surfaces, lessening the natural absorption of surrounding areas and increasing the runoff into the creek. In 1950, the U.S. Congress authorized the U.S. Army Corps of Engineers to intervene in the situation, but their first plan was shelved due to local residents' opposition against a tax collection scheme to modify the original boundaries of the Johnson Creek Water District (Johnson, 2008). After a catastrophic flood event occurred in 1964, many agencies such as the U.S. Army Corps of Engineers, the Soil Conservation Service, and the Metropolitan Service District (Metro) worked together to find solutions to flooding, but no success was achieved because of conflicts between residents living in the floodplains and those living in the upstream (Johnson, 2008). While continuing 'doing nothing' for about 40 years, industrial and residential development activities have taken place in frequently flooded areas along Jonson Creek in the late 1980s through the 1990s (Johnson, 2008; Bureau of Environmental Services, 2018a).

In 1973, the State of Oregon adopted 19 statewide planning goals and guidelines that must be implemented in a comprehensive plan for each city and county in the state. Goal 7 specifically applies to natural hazards, and calls for local plans to include inventories, policies and ordinances to guide development in hazard areas thereby 
reducing losses. In 1980, the City of Portland established a comprehensive plan by Ordinance No. 150580 in accordance with statewide goals, and adopted the Johnson Creek Basin Protection Plan in the amendment of 1991. Since then, BES as a leading water resource protection agency has been playing a key role in reducing the physical aspect of flood vulnerability in the Johnson Creek area through various stormwater management projects ${ }^{9}$.

In 1997, as a part of the Johnson Creek restoration project, BES developed the 'Johnson Creek Willing Seller Land Acquisition Program' in order to reconnect floodplains and enhance fish and wildlife habitat by relocating residents out of flooding areas. Working for about 15 years through the Willing Seller program, the City of Portland purchased the land from 60 families and restored 63 acres of wetland and floodplain habitat (Bureau of Environmental Services, 2018b), and finally, completed the Foster Floodplain Restoration Project in 2012. The Foster Floodplain Natural Area is now considered effective in reducing nuisance floods in the Johnson Creek area (Ahilan et al., 2018). Along with this effort, the City of Portland has been participating in FEMA's Community Rating System (CRS) since 2001, which is a voluntary program that rewards communities for taking action beyond minimum standards of the National Flood Insurance Program (NFIP). The Community Rating System Provides for 10 classes, with Class 1 having the most premium credit and communities in Class 10 receiving none

${ }^{9}$ Currently, five stormwater management projects (Johnson Creek Willing Seller Program, West Lents Flood Mitigation, East Lents Area Flood Project, Other Johnson Creek Target Area Floodplain Project, and Johnson Creek Restoration Project) are specified as significant projects for the Johnson Creek watershed and surrounding neighborhoods in the Portland's 2035 comprehensive plan. 
(FEMA, 2017). As a Class 6 community, the City of Portland currently receives a $20 \%$ discount on flood insurance premiums (Bureau of Environmental Services, 2018c). As shown in Table 5, the Community Rating System has 19 creditable activities that fall into four series. In order to fulfill FEMA's requirements, the City of Portland designed the Flood Insurance Savings Program to offer Elevation Certificates ${ }^{10}$, home assessments, and insurance counseling to stabilize low-income homeowners by saving money on their flood insurance. According to Portland Housing Bureau, the City of Portland served 33 homeowners through the program, and helped them to achieve average annual premiums of $\$ 1,195$ with a range of $\$ 385$ to $\$ 6,921$ in 2016 .

10 Elevation Certificates are official documentation from a surveyor that certifies the Base Flood Elevation (BFE) of a structure. Generally, flood insurance rates are based on where the lowest floor of a structure is in relation to the BFE. Flood insurance rates go up when the lowest floor of a structure is lower than the BFE. 
[Table 5] Credit points awarded for Community Rating System activities

\begin{tabular}{c|l|c|c|c}
\hline Series & \multicolumn{1}{|c|}{ Activity } & $\begin{array}{c}\text { Maximum } \\
\text { possible } \\
\text { points }\end{array}$ & $\begin{array}{c}\text { Average } \\
\text { points } \\
\text { earned }\end{array}$ & $\begin{array}{c}\text { Percentage of } \\
\text { communities } \\
\text { credited }\end{array}$ \\
\hline \hline 300 & Public Information Activities & & & \\
\hline 310 & Elevation Certificates & 116 & 38 & $96 \%$ \\
\hline 320 & Map Information Service & 90 & 73 & $85 \%$ \\
\hline 330 & Outreach Projects & 350 & 87 & $93 \%$ \\
\hline 340 & Hazard Disclosure & 80 & 14 & $84 \%$ \\
\hline 350 & Flood Protection Information & 125 & 38 & $87 \%$ \\
\hline 360 & Flood Protection Assistance & 110 & 55 & $41 \%$ \\
\hline 370 & Flood Insurance Promotion & 110 & 39 & $4 \%$ \\
\hline
\end{tabular}

\begin{tabular}{c|l|c|c|c}
\hline 400 & Mapping and Regulations & & & \\
\hline 410 & Flood Hazard Mapping & 802 & 60 & $55 \%$ \\
\hline 420 & Open Space Preservation & 2,020 & 509 & $89 \%$ \\
\hline 430 & Higher Regulatory Standards & 2,042 & 270 & $100 \%$ \\
\hline 440 & Flood Data Maintenance & 222 & 115 & $95 \%$ \\
\hline 450 & Stormwater Management & 755 & 132 & $87 \%$ \\
\hline
\end{tabular}

\begin{tabular}{l|l|c|c|c}
\hline 500 & Flood Damage Reduction Activities & & & \\
\hline 510 & Floodplain Management Planning & 622 & 175 & $64 \%$ \\
\hline 520 & Acquisition and Relocation & 2,250 & 195 & $28 \%$ \\
\hline 530 & Flood Protection & 1,600 & 73 & $13 \%$ \\
\hline 540 & Drainage System Maintenance & 570 & 218 & $43 \%$ \\
\hline
\end{tabular}

\begin{tabular}{c|l|c|c|c}
\hline 600 & Warning and Response & & & \\
\hline 610 & Flood Warning and Response & 395 & 254 & $20 \%$ \\
\hline 620 & Levees & 235 & 157 & $0.5 \%$ \\
\hline 630 & Dams & 160 & 35 & $35 \%$ \\
\hline
\end{tabular}

The data are based on communities that have received verified credit under the 2013 CRS Coordinator's Manual (about $43 \%$ of CRS communities), as of October 2016. The maximum possible points are based on the 2013 Coordinator's Manual. Growth adjustments are not included.

Source: FEMA'S National Flood Insurance Program: Community Rating System Coordinator's Manual, 2017

From a policy development perspective, it is noticeable that there have been constant efforts to achieve public engagement and consensus building in Johnson Creek flood mitigation process. Before the 1980s, all solutions were generated through a top- 
down, engineering approach, and thus, residents were always involved after the flood mitigation plans had been initiated by government and relevant agencies (Johnson 2008). Since the 1990s, Portland has strived to build civic infrastructure by adopting a collaborative, bottom-up approach that focuses on engaging all involved parties in decision-making process. One of the most important acts was the establishment of the Johnson Creek Corridor Committee (JCCC) in 1990. The main goal of JCCC was to resolve competing demands of various interest groups as a facilitating organization across six different jurisdictional and regulatory boundaries. After a series of periodic meetings with various inter-jurisdictional stakeholders, the JCCC developed the Johnson Creek Resources Management Plan in 1995 that outlined conceptual projects in four major categories - flooding, water quality, fish and wildlife habitat and stewardship (Bureau of Environmental Services, 2001). Since then, citizen groups and community volunteers became directly involved in Johnson Creek restoration and eventually led to the formation of the Johnson Creek Watershed Council (JCWC) in 1995, a grassroots nonprofit organization committed to restoring Johnson Creek through active community engagement. Today, the JCWC is playing an important role in enhancing ecological functions of Johnson Creek, and educating residents about planning processes and compliance with state and federal regulations.

The City of Portland has actively incorporated statewide goals into the comprehensive plan, and made considerable efforts to reduce Johnson Creek floods in a systematic and organized manner. Meanwhile, it is still debatable whether the city has 
been successfully addressing environmental justice issues associated with Johnson Creek floods. Portland's efforts to restore a floodplain and natural creek dynamics have contributed to reduce the frequency of flood events, but some neighborhoods in a designated flood zone such as the Lents and Powellhurst-Gilbert neighborhoods are still facing potential flood risks that are not likely to be prevented by the current approach. Based on the premise that environmental justice in natural disaster mitigation can be achieved by understanding and reducing human vulnerability, holistic assessments on both physical and socioeconomic aspects of flood vulnerability are still needed to ensure a deliberate process of developing and implementing strategies that adequately meet residents' needs and conditions.

From this point of view, the National Flood Insurance Program cannot be considered an acceptable long-term solution because its primary purpose is to provide policyholders with an economic safety net rather than to address root causes of flood problems. Moreover, it is not a suitable short-term solution either because high rates and limited coverage of flood insurance can be a financial burden and an added strain to low-income populations. From an environmental justice perspective, flood insurance, as a general duty and sometimes as a legal obligation, raises equity issues for both socioeconomically vulnerable groups and residents who do not feel floods as an immediate threat but are forced to pay high flood insurance rates. Without further policy alternatives for cost-sharing and differentiated subsidies, flood insurance may be considered the evasion of institutional responsibility that merely spreads the monetary 
loss over a wider population sector.

The Foster Floodplain Restoration Project also raises an ethical dilemma in implementing disaster policy. Obviously, the program offered an innovative solution to reduce potential flood risks while providing residents opportunities to decide whether to leave or not. From a utilitarian perspective, relocating people out of the flood zone and utilizing the area as a flood storage basin would be considered a rational land-use action that creates the greatest benefits for the majority of people. However, from a libertarian perspective, this can be viewed as imposing collective responsibility on a certain group of people who may be unwilling to leave the place because of their strong attachment to the neighborhood or other various socioeconomic constraints. Even though, BES specified that owners were under no obligation to sell their land and property to the city, it is difficult to say that no one was worried about the possibility of condemnation if they did not chose to sell their property. Moreover, considering that the program was initiated to restore the Foster Floodplain Natural Area, it is doubtful that BES initially took into account the partial purchase of site lands or the indefinite extension of the program as an option for the case when residents refuse to sell their properties.

The Wiling Seller Program in this respect leads to the moral question of whether property rights as negative human rights can be compromised or sacrificed in the name of public safety. As discussed in chapter 2, in the discourse of environmental justice, there are no clear answers to the problem of what to do when certain rights conflict with other important societal values. Even if a policy decision that upholds public safety 
prior to individual property rights was made based on social consensus, governmental institutions are still required to generate relevant alternatives regarding environmental injustice problems that can be unfairly imposed on socioeconomically vulnerable and disadvantaged populations. In this case, one alterative may be providing property sellers new or affordable housing options in a safe part of neighborhood so that they can be helped to relieve their financial pressure while not feeling a loss of neighborhood cohesion and community belonging.

Indeed, environmentally just and equitable solutions can be addressed and promoted through the expansion of institutional moral responsibility and diversified policy supports for socioeconomically vulnerable populations. At this point, it is important to ensure that moral conflicts in natural disaster mitigation should not be framed as meaningless or unsolvable problem. Arguably, the purpose of natural disaster mitigation policy and planning should be to build a shared understanding of community through collaborative and participatory discussions on various moral questions that can be much deeper, more dangerous and have greater consequences if left unaddressed and ignored.

\section{3-2. Flood Vulnerability Assessment}

Through institutions and policy analysis, it was found that governments' policy efforts to mitigate natural disasters do not cope with environmental justice issues, and disaster policies thus should be reinforced in a way to better reflect local vulnerability conditions and needs. Hence, this study attempted to develop a set of flood vulnerability 
indicators that enable flood experts and urban practitioners to understand the current condition and needs of local communities in a comprehensive and systematic way. The indicator-based method has been widely used in disaster vulnerability studies and preferred by policy makers for its clarified vulnerability image over space, a depiction which aims to prioritize measures and plan for the risk response in specified region (Nasiri et al., 2016). Historically, the evaluation of vulnerability was conceived to support technical and financial choices for protection against natural disasters, but today it became an object of social debate which should lead to explicit collective choices (Barroca et al., 2006). Unlike a model-based approach that mainly focuses on estimating flooding depth, extents and flow distribution velocities, the indicator-based method allows to understand locality as an interaction of physical and socioeconomic factors and, establish a shared agreement that helps guide and prioritize institutional responses to flood risks.

\section{3-2-1. Flood Expert Survey}

For an effective flood vulnerability assessment, appropriate indicators that are capable of representing both the physical and socioeconomic sources of vulnerability in the site area need to be selected. As a first step of the assessment process, this study thus conducted a flood expert survey to obtain preliminary information on current flood risks of Johnson Creek. Flood experts in the City of Portland have been concerned about Johnson Creek floods for a long time. The Portland's Bureau of Environmental Services (BES) and the Technical Advisory Committee (TAC) assembled by the Johnson Creek 
Watershed Council (JCWC) are two groups in particular that have been making continuous efforts to reduce flood risks and restore the native ecological functions of Johnson Creek. As well-informed sources, this study utilized their knowledge and experience to better understand environmental, social and historical situations of the Johnson Creek site area.

The survey was distributed to flood experts (hydrologist, engineers, water resource managers, ecologists and urban planners, etc.) working for the City of Portland and other agencies in the Portland metro area. Sixty-two participants with various academic backgrounds and experience levels were identified via snowball sampling and recruited voluntarily through email requests. As attached in Appendix $A$, the survey consisted of four groups of questions (Johnson Creek floods, flood disasters and environmental justice, flood vulnerability assessment, and respondent's demographic information). The survey, administered online, was conducted from January $3^{\text {rd }}$ to February $2^{\text {nd }}, 2018$ and a total of 30 people fully completed the survey in this period. The final response rate was $48.39 \%$. All survey responses were compiled and summarized through the Qualtrics online survey platform.

According to the survey results, most participants perceived the Johnson Creek floods as 'problematic' (96\%), and agreed that Johnson Creek is more prone to floods than other rivers and creeks within the Portland metro area (93\%). Seventy-nine percent of respondents said that Johnson Creek floods are caused by both natural factors and human activities, and $83 \%$ expected that the flood risk of Johnson Creek will be more 
severe in the future. While the majority of participants agreed that floods affect socioeconomically vulnerable populations most $(89 \%)$ and each community in the Johnson Creek area has a different capacity to prepare for, respond to, and recover from flood events (97\%), only 59\% replied that Johnson Creek floods are a socioeconomic problem rather than a technological and engineering problem.

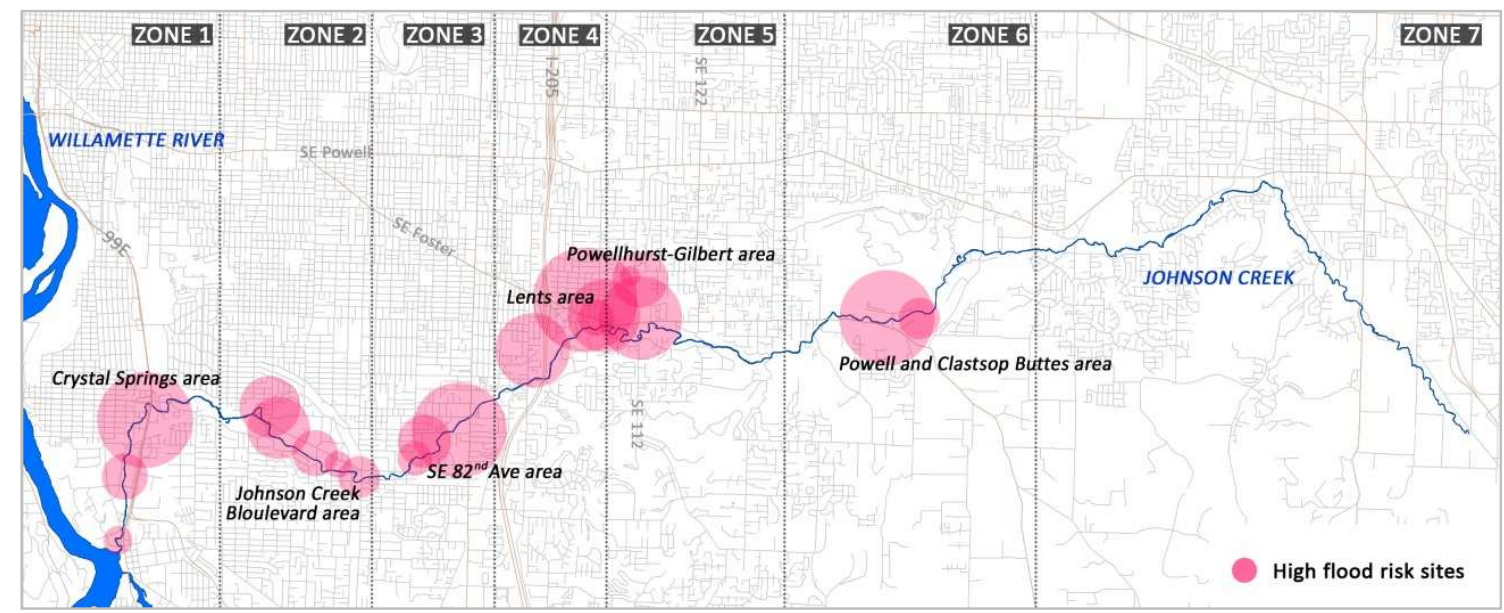

[Figure 4] High flood risk areas along Johnson Creek identified by flood experts

During the survey, participants were asked to indicate high flood risks sites based on their own perception. As shown in Figure 4, high flood risk sites identified by flood experts can be grouped into six areas: Crystal Springs area, Johnson Creek Boulevard area, SE $82^{\text {nd }}$ Avenue area, Lents area, Powellhurst-Gilbert area, and Powell and Clastsop Buttes area. These areas are mainly located along the mid and lower reaches of Johnson Creek and show similar spatial extent with FEMA designated floodplains. Based on this observation, the study site was divided into seven zones, and they became spatial boundaries to compare physical and socioeconomic flood vulnerability results. 
Nearly half of participants selected 'floodplain development' as the major cause of Johnson Creek floods (48\%). They chose both the 'lack of structural flood control measures' and 'differences in local residents' socioeconomic capacity to cope with flood risks' as the second (21\%), and 'insufficient institutional and policy support' as the third cause of Johnson Creek floods (10\%).

It is noticeable that the majority of respondents believed that environmental justice is a critical part of flood mitigation policy and planning (93\%), and human rights must be placed at the center of flood risk management (81\%). In relation to this, flood experts replied that Johnson Creek floods are a city-wide problem rather than a neighborhood problem (86\%), and local government has responsibility to take care of socioeconomically vulnerable populations (96\%). Participants ranked the 'leadership, political will and vision' as the most important component of environmental justice, followed by 'sufficient funding and policy support' and 'more non-governmental organization to support socioeconomically vulnerable populations'. 'Active and meaningful public participation' and 'high level of awareness of socioeconomic disparities in society' were the fourth and the fifth, respectively.

Most importantly, flood experts identified a total of 20 flood vulnerability indicators that are site-specific for the Johnson Creek area. For this, 10 physical and 10 socioeconomic flood vulnerability indicators were firstly gathered from a literature review and ordered alphabetically to avoid selection bias toward one particular aspect of flood vulnerability. During the survey, participants were then asked which indicators 
should be considered importantly and what other indicators should be included for the Johnson Creek flood vulnerability assessment.

In this survey, all participants agreed that both physical and socioeconomic vulnerability should be considered for successful flood mitigation. Flood experts replied that all 20 proposed indicators are relevant for the Johnson Creek flood vulnerability assessment, and approximately $20 \%$ of respondents particularly emphasized the importance of socioeconomic flood vulnerability indicators such as poverty, people of color, age and English proficiency. Some participants suggested additional flood vulnerability indicators such as emergency preparedness, communities' plan for climate change, length or residence, homelessness, flood insurance, and telecommunications infrastructures. These indicators, however, were excluded from the assessment because they were addressed by relatively few participants, their definitions were vague, or there were difficulties in collecting and interpreting related data. Table 6 describes the flood vulnerability indicators rated as 'very important' or 'somewhat important' by flood experts. 
[Table 6] Johnson Creek flood vulnerability indicators rated by flood experts

\begin{tabular}{|c|c|c|c|c|}
\hline Indicator & Explanation & $\begin{array}{c}\text { Very } \\
\text { important }\end{array}$ & $\begin{array}{l}\text { Somewhat } \\
\text { important }\end{array}$ & $\begin{array}{c}\text { Not } \\
\text { important }\end{array}$ \\
\hline Age & $\begin{array}{l}\text { Percentage of aged residents who have difficulties evacuating a building } \\
\text { independently in case of an emergency (e.g., Under } 18 \text { and over 64) }\end{array}$ & $69.23 \%$ & $30.77 \%$ & $0.00 \%$ \\
\hline Age of structure & Percentage of old buildings (e.g., Buildings constructed before 1950) & $34.62 \%$ & $53.85 \%$ & $11.54 \%$ \\
\hline Contamination & $\begin{array}{l}\text { Concentration of contaminated sites (e.g., Underground storage tank, } \\
\text { Hazardous waste site, Extremely hazardous substance site) }\end{array}$ & $61.54 \%$ & $34.62 \%$ & $3.85 \%$ \\
\hline Disability & Percentage of residents with physical or mental disabilities & $69.23 \%$ & $30.77 \%$ & $0.00 \%$ \\
\hline Economic activity & Percentage of households with self-employment income & $30.77 \%$ & $46.15 \%$ & $23.08 \%$ \\
\hline Education & Percentage of people with less than high school diploma & $23.08 \%$ & $65.38 \%$ & $11.54 \%$ \\
\hline Ethnicity/Race & Percentage of residents from communities of color & $57.69 \%$ & $38.46 \%$ & $3.85 \%$ \\
\hline Green space & Area of green space that could effectively hold flood waters & $65.38 \%$ & $26.92 \%$ & $7.69 \%$ \\
\hline Hospital & Proximity to hospitals & $46.15 \%$ & $34.62 \%$ & $19.23 \%$ \\
\hline Household size & Percentage of 5 or more person family and nonfamily households & $26.92 \%$ & $65.38 \%$ & $7.69 \%$ \\
\hline Housing type & $\begin{array}{l}\text { Percentage of residents who have less ability or incentive to take } \\
\text { mitigation action (e.g., Rental dwellings) }\end{array}$ & $61.54 \%$ & $34.62 \%$ & $3.85 \%$ \\
\hline Initial emergency response & Proximity from fire stations & $61.54 \%$ & $30.77 \%$ & $7.69 \%$ \\
\hline Language & Percentage of residents who speak English 'not well' or 'not at all' & $61.54 \%$ & $34.62 \%$ & $3.85 \%$ \\
\hline Location & Distance from floodplains and ground elevation & $88.46 \%$ & $7.69 \%$ & $3.85 \%$ \\
\hline Population density & Total population per area & $53.85 \%$ & $42.31 \%$ & $3.85 \%$ \\
\hline Poverty & Percentage of households living below the federal poverty line & $69.23 \%$ & $30.77 \%$ & $0.00 \%$ \\
\hline Shelter & Proximity to shelters (e.g., Public school, Library, Community center) & $57.69 \%$ & $26.92 \%$ & $15.38 \%$ \\
\hline Stormwater infrastructure & $\begin{array}{l}\text { Length of stormwater flow pathways (e.g., Constructed channel, Ditch, } \\
\text { Green street facility) }\end{array}$ & $65.38 \%$ & $19.23 \%$ & $15.38 \%$ \\
\hline Transportation & Public transportation options ( e.g., MAX, Streetcar, Bus) & $38.46 \%$ & $50.00 \%$ & $11.54 \%$ \\
\hline Unemployment & Percentage of people in the civilian labor force who are not working & $26.92 \%$ & $61.54 \%$ & $11.54 \%$ \\
\hline
\end{tabular}




\section{3-2-2. GIS Spatial Analysis}

Based on the indicators derived from the flood expert surveys, this study attempted to quantitatively visualize flood vulnerability of the Johnson Creek area using Geographic Information System (GIS). GIS is a useful and important tool to integrate spatial data and produce flood vulnerability maps that can be easily compared and combined. In this study, the spatial analysis provides an effective means to investigate the most vulnerable neighborhoods to potential future flood events, and whether there exist spatial differences between physically and socioeconomically vulnerable neighborhoods within the Johnson Creek site area. In doing so, it provides the evidence base for further discussion on the potential and limitations of current flood mitigation policy and planning from an environmental justice point of view.

\section{1) Methodology}

First, a total of 51 census block groups (CBGs) that include FEMA designated 100-year and 500-year floodplains were selected as potential flood risk zones. FEMA floodplains data are the most readily accessed flood study products and a baseline for mandatory flood insurance purchase. The 100-year and 500-year flood events represent a $1 \%$ and a $0.2 \%$ chance of flooding in any given year, respectively. The 500 -year flood event which affects wider areas is normally regarded as a rare but catastrophic flood. CBGs are used as a geographic unit of analysis because they are the smallest geographic areas for which census data are collected and reported. After comparing aerial imagery with FEMA floodplain maps and digital elevation model (DEM) data, high ground areas 
with an elevation of $120 \mathrm{~m}$ and above were selected as a flood-safe zone, and therefore, excluded from the analysis using a 3-feet resolution LiDAR data. Spatial data were collected from Metro's Regional Land Information System (RLIS), and all attributed data were obtained from the U.S. Census Bureau. This study mainly used the latest 2016 5year American Community Survey (ACS) data for demographic and economic information.

Second, the definitions of each indicator were adjusted and sharpened in consideration of local characteristics and data availability. Considering that the concept of vulnerability is multi-dimensional and context-specific, it is essential to acknowledge that a set of indicators and definitions used in this analysis are designed for the relative comparisons of flood vulnerability among Johnson Creek neighborhoods, and not intended as a reference for absolute comparisons between any two neighborhoods with different geographical and socioeconomic characteristics. Certainly, assessing vulnerability needs to be understood as heuristic process of how we are assigning a meaning to indicator and defining the value and function of the indicator in the context of confronting issues. Definitions used in this analysis, represent one of many possible methods of evaluating corresponding indicators, and thus, can be changed or modified based on different perspectives and understandings on the situation.

Lastly, the following assumptions were made in order to simplify the problem and minimize variation in interpretation:

- It is possible to move around the site and cross the creek in the flood situation. 
- Each indicator is independent of each other and does not affect the assessment of other indicators. For example, poverty status is assumed to be not associated with unemployment even though there may be some relationship between the two indicators.

- The spatial variability within a CBG was not taken into account given the relatively small geographical nature of CBG and no disaggregated data are available at a finer scale other than $\mathrm{CBG}$.

- A relative importance of each indicator is not taken into account in this analysis. However, it is still important to understand that a vulnerability value of one indicator cannot be considered equally important with a same value of other indicators because each indicator has different meaning and relevance to people depending on their particular concerns.

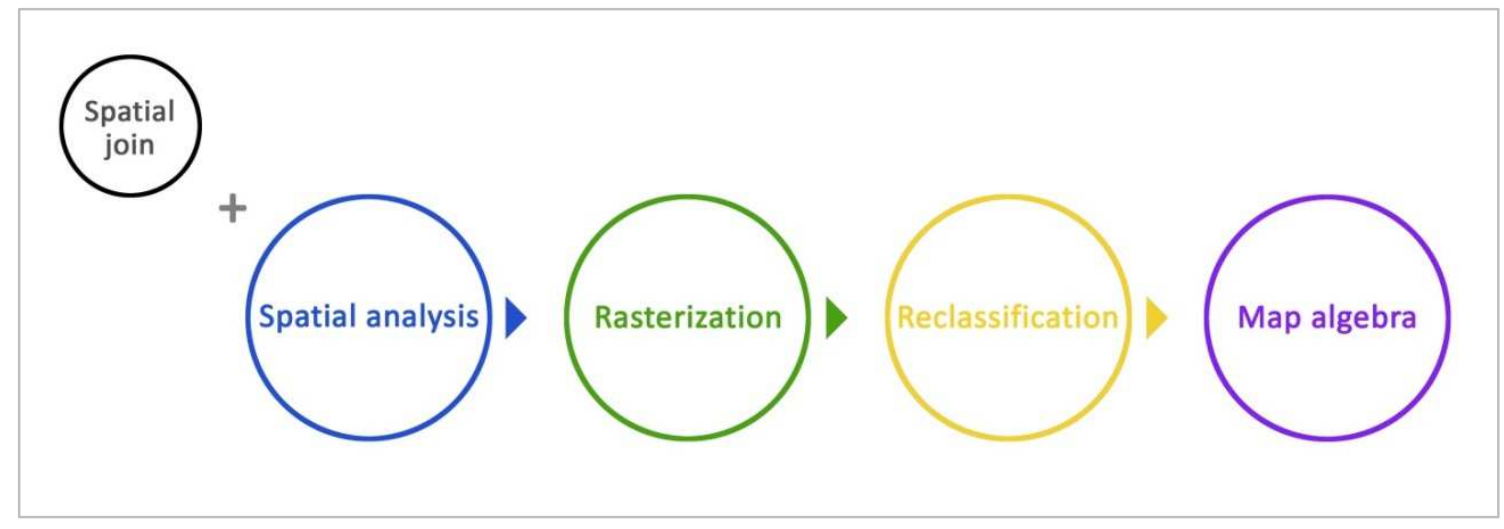

[Figure 5] Process of GIS-based flood vulnerability assessment

In this analysis, as shown in Figure 5, each flood vulnerability result was converted to raster with a resolution of $15 \mathrm{~m} \times 15 \mathrm{~m}$ in order to obtain integrated results 
of flood vulnerability. They were reclassified by assigning the scores from 1 to 5 , and then map algebra was used to combine independent results on a cell-by-cell basis. In this analysis, darker colors and higher reclassified numbers represent census block groups with higher flood vulnerability.

\section{2) Johnson Creek Flood Vulnerability Assessment}

Based on selected indicators and their definitions in Table 7, both physical and socioeconomic flood vulnerability were analyzed using various types of GIS analysis functions that are considered to be most suitable to measure each indicator. Each indicator was graphically represented and compared using a five-class quantile classification which distributes a set of values into five groups that contain an equal number of values. Both physical and socioeconomic flood vulnerability results of each individual indicator are shown in Appendix B-1 and B-2, respectively. 
[Table 7] Johnson Creek flood vulnerability indicators

1. Physical flood vulnerability indicators

\begin{tabular}{|c|c|c|c|c|c|}
\hline No. & Indicator & Definition & Analysis type & Attribute data & Unit \\
\hline 1 & Location & $\begin{array}{l}\text { Distance from } 500 \text {-year floodplains (Ground } \\
\text { elevation between } 0 \text { to } 120 \mathrm{~m} \text { ) }\end{array}$ & $\begin{array}{l}\text { Euclidean } \\
\text { distance }\end{array}$ & - & Meter \\
\hline 2 & Contamination & $\begin{array}{l}\text { Concentration of contaminated sites } \\
\text { (Underground storage tank, Leaking } \\
\text { underground storage tank, Hazard waste site, } \\
\text { Extremely hazardous site) }\end{array}$ & Point density & - & Points/Km² \\
\hline 3 & $\begin{array}{l}\text { Stormwater } \\
\text { infrastructure }\end{array}$ & $\begin{array}{l}\text { System capacity for handling storm and surface } \\
\text { runoff (Constructed channel, Ditch, Green street } \\
\text { facility) }\end{array}$ & Line density & - & Meter/Km² \\
\hline 4 & Age of structure & Percentage of building constructed before 1950 & Tabulate area & - & Percentage \\
\hline 5 & Green space & $\begin{array}{l}\text { Area of green space that could effectively hold } \\
\text { flood waters (Vegetation, Wetland) }\end{array}$ & Tabulate area & - & Percentage \\
\hline 6 & Transportation options & $\begin{array}{l}\text { Density of public transportation stops (MAX, } \\
\text { Streetcar, Bus) }\end{array}$ & Point density & - & Points/Km² \\
\hline 7 & Shelter & $\begin{array}{l}\text { Proximity to shelters (Public school, Library, } \\
\text { Community center, Shelter organization) }\end{array}$ & $\begin{array}{l}\text { Euclidean } \\
\text { distance }\end{array}$ & - & Meter \\
\hline 8 & Hospital & Proximity to hospitals & $\begin{array}{l}\text { Euclidean } \\
\text { distance }\end{array}$ & - & Meter \\
\hline 9 & $\begin{array}{l}\text { Initial emergency } \\
\text { response }\end{array}$ & Proximity from fire stations & $\begin{array}{l}\text { Euclidean } \\
\text { distance }\end{array}$ & - & Meter \\
\hline 10 & Population density & Total population per area & Spatial join & $\begin{array}{l}2016 \text { ACS 5-year estimates } \\
\text { (B01003) }\end{array}$ & Persons $/ \mathrm{Km}^{2}$ \\
\hline
\end{tabular}


2. Socioeconomic flood vulnerability indicators

\begin{tabular}{|c|c|c|c|c|c|}
\hline No. & Indicator & Definition & Analysis type & Attribute data & Unit \\
\hline 1 & Poverty & $\begin{array}{l}\text { Percentage of households living below the } \\
\text { federal poverty line }\end{array}$ & Spatial join & $\begin{array}{c}2016 \text { ACS 5-year estimates } \\
\text { (B17017) }\end{array}$ & Percentage \\
\hline 2 & Economic activity & $\begin{array}{l}\text { Percentage of households with self-employment } \\
\text { income }\end{array}$ & Spatial join & $\begin{array}{c}2016 \text { ACS 5-year estimates } \\
\text { (B19053) }\end{array}$ & Percentage \\
\hline 3 & Age & $\begin{array}{l}\text { Percentage of residents under } 18 \text { and over } 64 \\
\text { years of age }\end{array}$ & Spatial join & $\begin{array}{c}2016 \text { ACS 5-year estimates } \\
\text { (B01001) }\end{array}$ & Percentage \\
\hline 4 & Housing type & Percentage of rental households & Spatial join & $\begin{array}{c}2016 \text { ACS 5-year estimates } \\
\text { (B25003) }\end{array}$ & Percentage \\
\hline 5 & Household size & $\begin{array}{l}\text { Percentage of } 5 \text { or more person family and } \\
\text { nonfamily households }\end{array}$ & Spatial join & $\begin{array}{c}2016 \text { ACS 5-year estimates } \\
\text { (B11016) }\end{array}$ & Percentage \\
\hline 6 & Community of color & $\begin{array}{l}\text { Percentage of residents from communities of } \\
\text { colors }\end{array}$ & Spatial join & $\begin{array}{c}2016 \text { ACS 5-year estimates } \\
\text { (B02001) }\end{array}$ & Percentage \\
\hline 7 & Disability & $\begin{array}{l}\text { Percentage of residents with physical or mental } \\
\text { disabilities (Ages 18-64) }\end{array}$ & Spatial join & $\begin{array}{c}2013 \text { ACS 5-year estimates } \\
\text { (C23023) }\end{array}$ & Percentage \\
\hline 8 & Language & $\begin{array}{l}\text { Percentage of residents who speak English 'not } \\
\text { well' or 'not at all' (Ages } 16 \text { and over) }\end{array}$ & Spatial join & $\begin{array}{c}2016 \text { ACS 5-year estimates } \\
\text { (B16004) }\end{array}$ & Percentage \\
\hline 9 & Unemployment & $\begin{array}{l}\text { Percentage of people in the civilian labor force } \\
\text { who are not working (Ages } 16 \text { and over) }\end{array}$ & Spatial join & $\begin{array}{c}2016 \text { ACS 5-year estimates } \\
\text { (B23025) }\end{array}$ & Percentage \\
\hline 10 & Education & $\begin{array}{l}\text { Percentage of people with less than high school } \\
\text { diploma (Ages } 25 \text { and over) }\end{array}$ & Spatial join & $\begin{array}{c}2016 \text { ACS 5-year estimates } \\
\text { (B15003) }\end{array}$ & Percentage \\
\hline
\end{tabular}



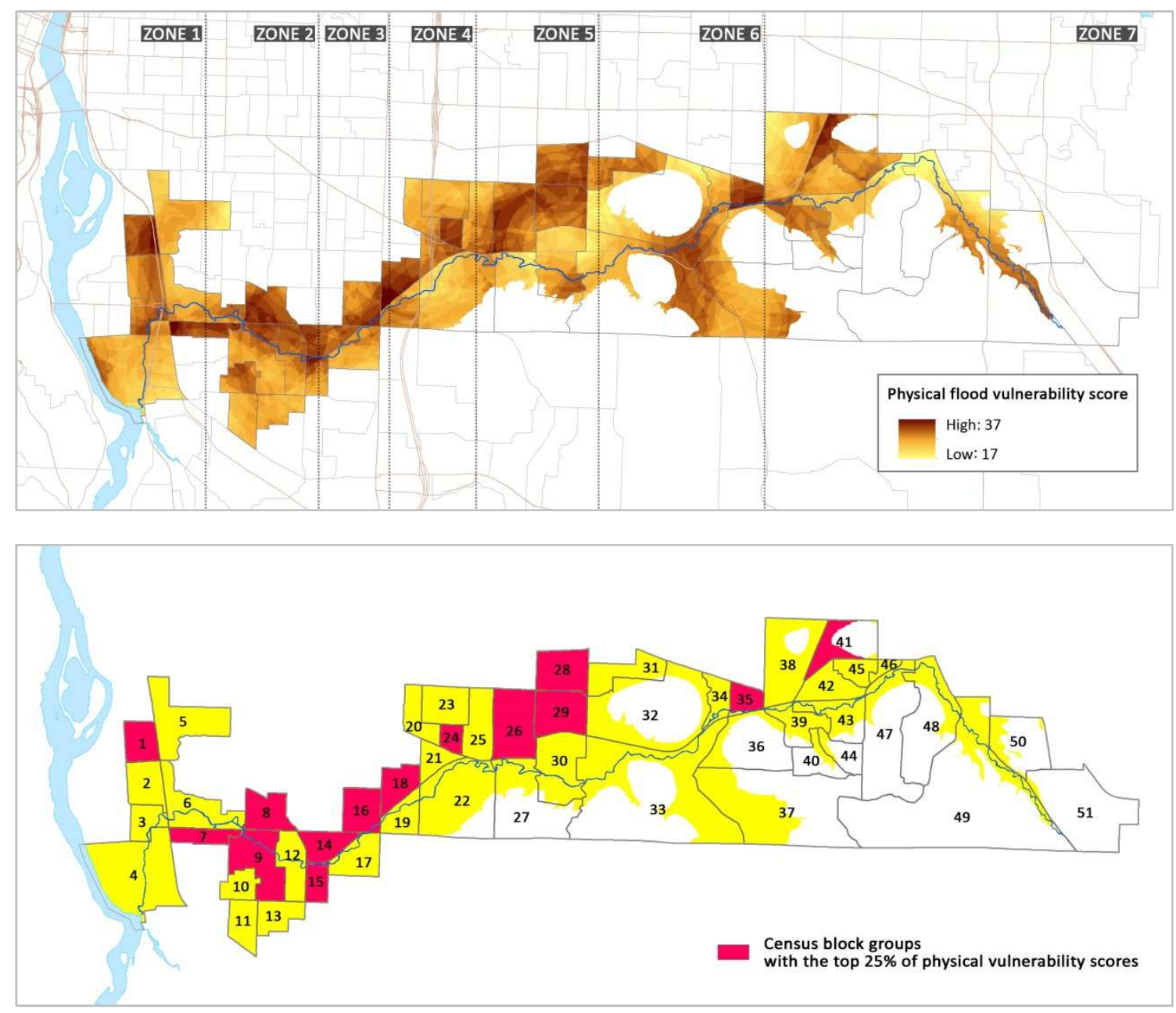

[Figure 6] Physical flood vulnerability score map

As represented in Figure 6, all ten individual results were spatially combined to investigate overall physical flood vulnerability of the study area. In this analysis, census block groups with the top $25 \%$ of vulnerability scores were selected and considered as high flood risk areas. The integrated result showed that physical vulnerability was relatively high in the lower and mid reaches of Johnson Creek. From zone 1 to 3, and partially 4, high flood risk areas were connected along the lower reach of the creek. In the mid reach, physical vulnerability was concentrated in the southwest and mid parts of 
Lents neighborhood (CBG 18 and 24), the Powellhurst-Gilbert neighborhood (CBG 26, 28 and 29), and the north of Jenne Butte Park (CBG 35). Physical flood vulnerability scores of all census block groups were in the medium risk range (17-37), and the total number of high flood risk CBGs was 14.
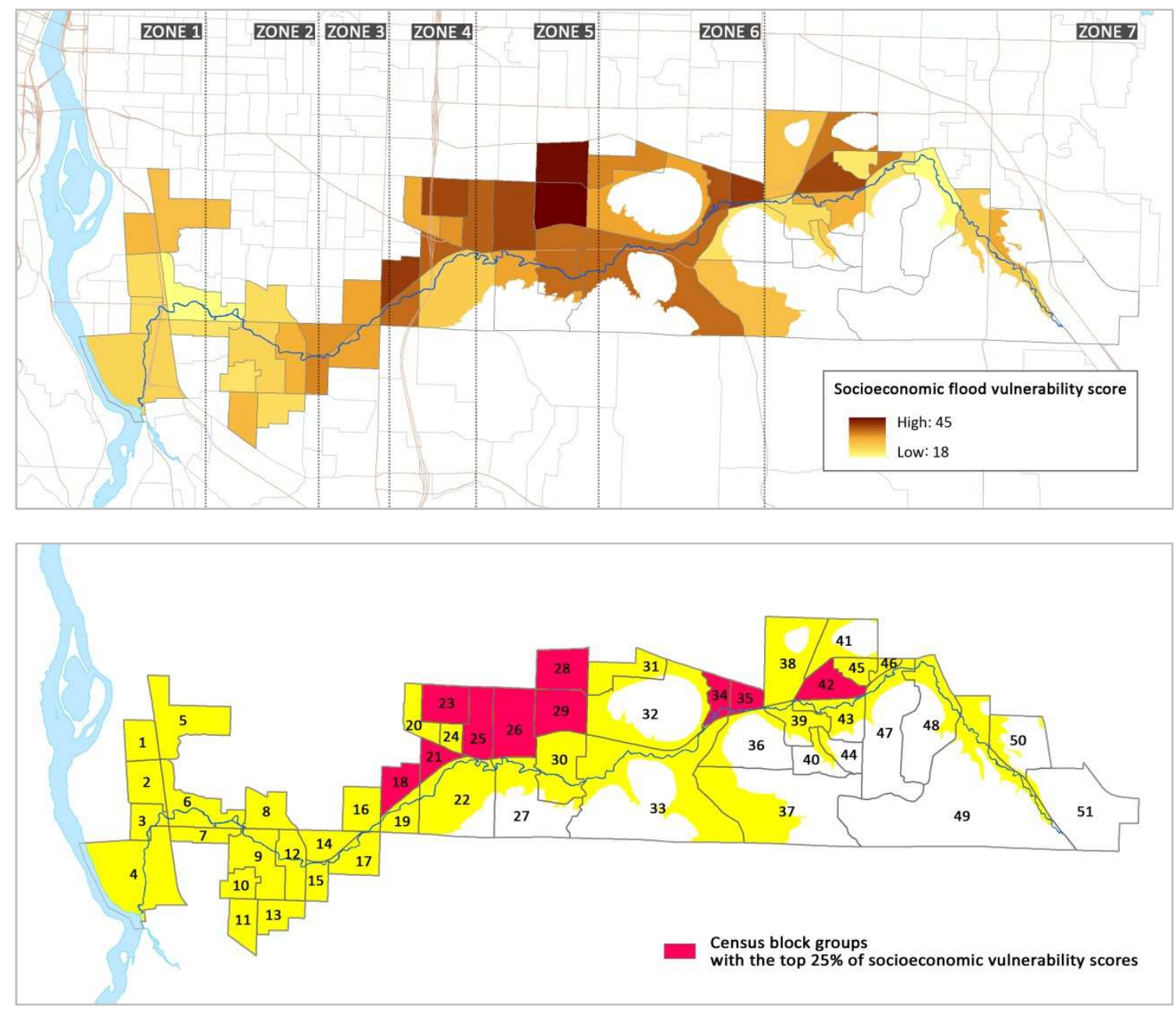

[Figure 7] Socioeconomic flood vulnerability score map

Meanwhile, socioeconomic vulnerability was relatively high in the mid reach of Johnson Creek. High flood risk areas were located in the Lents and the PowellhurstGilbert neighborhoods (CBG 18, 21, 23, 25, 26, 28 and 29), the Gresham Pleasant Valley 
neighborhood (CBG 34), and the north of Jenne Butte Park (CBG 35). Especially, census block group 28 and 29 in zone 5 showed markedly high socioeconomic vulnerability scores of 43 and 45, respectively. Socioeconomic flood vulnerability scores of all census block groups were in the high risk range (18-45), and the total number of high flood risk areas was 10. From the result, it was found that socioeconomic vulnerability was concentrated on a fewer number of census block groups but the score range was wider with a higher maximum score than that of physical vulnerability. This represents that socioeconomic vulnerability is likely to be more severely imposed upon certain groups of people in the Johnson Creek area.

In a similar way, all 20 physical and socioeconomic vulnerability results were summed up to obtain the integrated flood vulnerability scores of each census block group. As observed in Figure 8, the integrated vulnerability scores were relatively high in the Lents and Powellhurst-Gilbert neighborhoods and the north of Jenne Butte Park, especially in census block group 18, 26, 28, 29 and 35. This represents that Johnson Creek floods can be characterized as a socio-environmental problem that is confined to a small number of neighborhoods in the mid reach of Johnson Creek and that is caused by both physical and socioeconomic disadvantages that those neighborhoods face. 

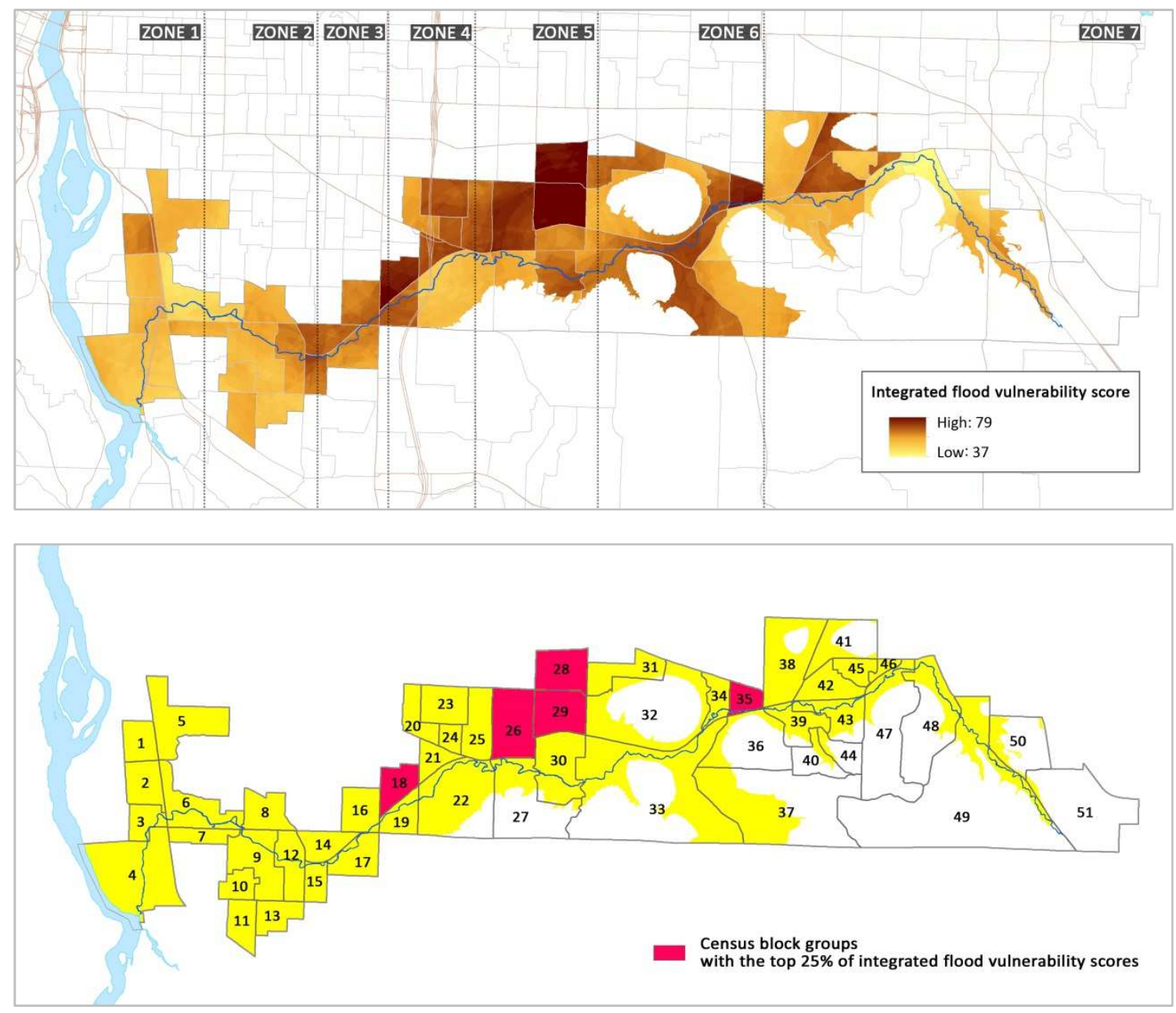

[Figure 8] Integrated flood vulnerability score map

In order to further investigate the locations of flood risk areas by their aspects and degrees of flood vulnerability, this analysis calculated and compared flood vulnerability scores of each census block group. For physical flood vulnerability, the average scores per area were used because of multiple flood vulnerability scores in a single census block group. As show in Figure 9, 51 census block groups were distinguished into four groups by the mean values of physical and socioeconomic vulnerability scores. Blue dots in group A, for example, represent census block groups 
with relatively high physical and low socioeconomic vulnerability, while red dots in group B represent census block groups with relatively high physical and high socioeconomic vulnerability.
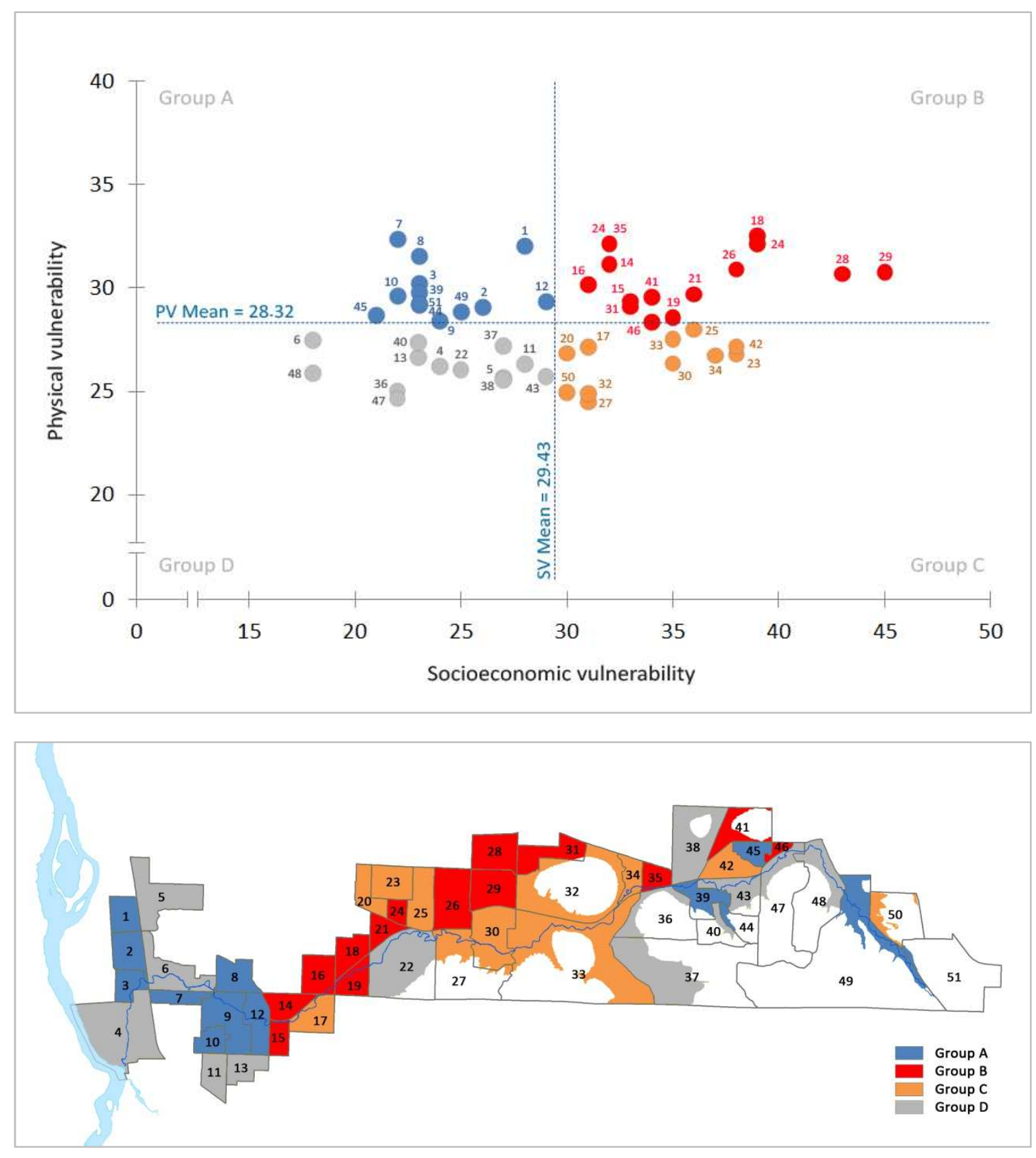

\begin{tabular}{c|c|c|c|c|c|c|c|c|c|c|c}
\hline CBG & 1 & 2 & 3 & 4 & 5 & 6 & 7 & 8 & 9 & 10 & 11 \\
\hline \hline PV & 32.06 & 29.18 & 30.24 & 26.22 & 25.65 & 27.47 & 32.40 & 31.56 & 28.43 & 29.64 & 26.31 \\
\hline SV & 28 & 23 & 23 & 24 & 27 & 18 & 22 & 23 & 24 & 22 & 28 \\
\hline
\end{tabular}




\begin{tabular}{|c|c|c|c|c|c|c|c|c|c|c|c|}
\hline CBG & 12 & 13 & 14 & 15 & 16 & 17 & 18 & 19 & 20 & 21 & 22 \\
\hline PV & 29.34 & 26.66 & 31.16 & 29.37 & 30.15 & 27.15 & 32.52 & 28.57 & 26.84 & 29.70 & 26.03 \\
\hline SV & 29 & 23 & 32 & 33 & 31 & 31 & 39 & 35 & 30 & 36 & 25 \\
\hline CBG & 23 & 24 & 25 & 26 & 27 & 28 & 29 & 30 & 31 & 32 & 33 \\
\hline PV & 26.79 & 32.14 & 27.99 & 30.91 & 24.48 & 30.68 & 30.77 & 26.34 & 29.09 & 24.91 & 27.51 \\
\hline SV & 38 & 32 & 36 & 38 & 31 & 43 & 45 & 35 & 33 & 31 & 35 \\
\hline CBG & 34 & 35 & 36 & 37 & 38 & 39 & 40 & 41 & 42 & 43 & 44 \\
\hline PV & 26.74 & 32.14 & 25.03 & 27.20 & 25.57 & 29.79 & 27.38 & 29.55 & 27.18 & 25.71 & 29.10 \\
\hline SV & 37 & 39 & 22 & 27 & 27 & 23 & 23 & 34 & 38 & 29 & 26 \\
\hline CBG & 45 & 46 & 47 & 48 & 49 & 50 & 51 & Min & Max & & \\
\hline PV & 28.72 & 28.36 & 24.64 & 25.88 & 28.86 & 24.96 & 29.23 & 24.48 & 32.52 & & \\
\hline SV & 21 & 34 & 22 & 18 & 25 & 30 & 23 & 18 & 45 & & \\
\hline
\end{tabular}

[Figure 9] Flood vulnerability scores of each census block group

The result showed that the majority of census block groups in group A were clustered in the lower reach, while those in group B and C were concentrated in the mid reach of Johnson Creek. In the upper reach, all groups were found with no predominant aspect of flood vulnerability. This demonstrates that differentiated policy options are required based on the particularity and difference of vulnerability conditions that communities are exposed to. For example, it may be considered to be rational and appropriate to use technical expertise and engineering support to implement more effective and cost-beneficial structural measures in the lower reach of Johnson Creek. Meanwhile, considering that high level of socioeconomic vulnerability is related to the lack of coping capacity, diversified long-term policy strategies should be developed to improve the overall quality of life of flood affected neighborhoods in the mid reach of Johnson Creek. Especially for group B areas where floods are a complex human vulnerability problem, it is required to provide suitable solutions through more in-depth 
investigation on influencing vulnerability factors and their correlations, and decide the direction and priorities of flood mitigation plans through a participatory and collaborative decision-making process.

Through the analysis, it became clear that flood problems can be approached differently depending on how we define vulnerability and which aspect of vulnerability we focus on. Moreover, this analysis confirmed that the possibility of indicator-based method in understanding both physical and socioeconomic vulnerability conditions of neighborhoods, and seeking more rational and reasonable solutions that reflect local realities. The results derived in this analysis call for better decisions in flood mitigation policy and planning about which neighborhoods should be targeted first, and which disadvantageous factors should be taken care of with more importance to reduce human vulnerability those neighborhoods face.

The results of flood vulnerability assessment support the findings of previous institutions and policy analysis in that local flood mitigation efforts are insufficient to address socioeconomic vulnerability that is more severely imposed on certain groups of people in the Johnson Creek area. In case of the Foster Floodplain Restoration, institutional efforts may be evaluated as an effective and suitable strategy to reduce physical flood vulnerability of the Lents and Powellhurst-Gilbert neighborhoods, which were identified as the highest flood risk areas in this analysis. However, considering that the level of socioeconomic flood vulnerability of these neighborhoods is significantly higher than the average, other alternative policies are also needed to enhance socio- 
environmental resilience to flood risks. The Foster Floodplain Natural Area successfully reduced the frequency of flood, but did not change the 100-year flood footprint (Bureau of Environmental Services, 2014). Moreover, many modest, single-family dwellings in the Lents and Powellhurst-Gilbert neighborhoods are still exposed to the risk of nuisance flooding and facing a heavy financial burden due to continuously increasing expenditure on flood insurance. Diversified and expanded institutional efforts in this respect are needed in order to reduce socioeconomic consequences of floods based on holistic understanding of the particularity and difference of vulnerability conditions that neighborhoods are currently exposed to. From an environmental justice perspective, comprehensive flood vulnerability assessment used in this study enables flood experts and policy makers to understand floods as a sociological phenomenon which extends beyond physical conditions, and provides clear and consistent grounds for selecting more rational and equitable solutions.

\section{3-3. Comparative Analysis of Perceptions on Flood Risk and Environmental Justice}

The next questions are how the idea of environmental justice is interpreted and adapted in actual flood risks management, and what are the challenges and barriers to bring the concept of human vulnerability and human rights, as a tool to address social consequences of natural disasters, into the decision-making process.

Indeed, environmental justice as a policy problem is still difficult to be solved because a policy problem is not only a matter of 'fact' but also a matter of 'interpretation' (Fischer, 1998). Since the concepts of human vulnerability and 
environmental justice are relative and hold a different meaning and value to everyone, natural disaster mitigation should be regarded as a practice of communication among individuals who have their own ideology, opinion, and belief rather than a process of verification based on objective analytical evidence. Contemporary natural disaster mitigation policy and planning is thus no longer a mere process of finding the best and most effective solution, but rather the practice of consensus building and social learning among participants (Cho and Chang, 2017). Accordingly, it becomes more important to understand individual's subjective perception on disaster risks and observe which environmental, social and ethical values are considered with a greater importance during the practice of natural disaster mitigation. For this reason, this study attempted to map various social and institutional discourses on flood risk and environmental justice using Q-methodology. Q-methodology was conducted based on opinions and subjective views of flood experts and urban practitioners in the City of Portland. It is because 1) they are potential innovators and implementers of an environmental justice discourse in the Johnson Creek flood risk management, and 2) as representatives of governmental institutions, their roles in providing services, promoting human rights, and advocating for adequate societal resources for disadvantaged populations are considered to be significantly important and influential.

\section{3-3-1. Q-Methodology}

Q-methodology is suitable for analyzing various opinions of experts and professionals in different fields because it is a self-referential method that reveals 
subjective preferences holistically in order to identify underlying philosophical and ideological viewpoints on an issue. In this study, Q-Methodology was used to group individuals according to their subjective feelings and opinions about the topics of flood risk and environmental justice, and to understand their thoughts on the relationship among social values, personal beliefs and institutional role and responsibility.

Q-methodology was developed by Stephenson with the idea in mind that problems in nature can be examined subjectively (Stephenson, 1986). A number of disciplines have employed Q-methodology to study topics such as social attitudes, decision-making, cultural values, public policy, and education practice including simulation-based learning (Paige, 2014). In Q-methodology, subjectivity is considered communicable and operant. Brown (1980) stated that the scientific study of a person's communication of his or her viewpoint cannot be right or wrong, and the use of subjectivity lets the researcher study the phenomenon directly from the internal standpoint of the participant. It is noticeable that researches using Q-methodology do not hypothesize beforehand. Instead of measuring variables that are predefined and operationalized from an external frame of reference, Stephenson sought to generate constructs from the person's own internal frame of reference. Consequently, Qmethodology makes it possible to provide a way of understanding each expression of subjectivity hermeneutically following an objective procedure that avoids projecting the researcher's frame of reference upon the person's communications. In this study, the procedure of Q-methodology can be divided into three parts: Q-sample preparation, Q- 
sorting process (participant's experience), and Q-factor analysis (researcher's interpretation).

\section{1) Q-Sample Preparation}

Q-methodology begins with the development of a set of statements called the 'Q-sample'. Identifying statements that cover the full range of view held about topic is vital to the success of Q-methodology, and therefore, thorough preparation is essential. As shown in Table 8, this study firstly set up four main topics that cover all issues and questions brought up throughout the study. This was intended to avoid the exclusion of meaningful statements by clarifying the focus and scope of analysis, and to highlight controversial issues and conflicting perspectives associated with the discourse of environmental justice. Topics in Table 8 provide an effective means of ensuring a balanced and representative set of statements, and consequently, bring a clear sense of system and rigidity to the Q-sample preparation process. 
[Table 8] Main topics and related discussions for the formulation of Q-sample

\begin{tabular}{|c|c|c|}
\hline \multicolumn{2}{|r|}{ Topics } & Discussions \\
\hline A & $\begin{array}{l}\text { The concept of } \\
\text { flood vulnerability }\end{array}$ & $\begin{array}{l}\text { - How do participants understand the concept of } \\
\text { flood vulnerability? } \\
\text { - Are participants aware of the meaning and } \\
\text { importance of human vulnerability? }\end{array}$ \\
\hline B & $\begin{array}{l}\text { The meaning of } \\
\text { environmental justice }\end{array}$ & $\begin{array}{l}\text { - How differently do participants interpret } \\
\text { environmental justice? } \\
\text { - Which social norms and values do participants } \\
\text { concern most? }\end{array}$ \\
\hline$C$ & $\begin{array}{l}\text { Institutional responsibility } \\
\text { in incorporating a vision of } \\
\text { environmental justice }\end{array}$ & $\begin{array}{l}\text { - What is the extent of institutional support for } \\
\text { people who are at risk of flooding? } \\
\text { - Does government have a moral obligation to help } \\
\text { socioeconomically vulnerable populations? }\end{array}$ \\
\hline $\mathrm{D}$ & $\begin{array}{l}\text { Different approaches to } \\
\text { flood risk management }\end{array}$ & $\begin{array}{l}\text { - What kind of information should be considered } \\
\text { importantly in flood risk management? } \\
\text { - What is the way to promote environmental justice } \\
\text { and reduce human vulnerability to flood risks? }\end{array}$ \\
\hline
\end{tabular}

A total of 35 Q-statements were initially generated through literature reviews and findings from previous flood expert surveys and flood vulnerability assessment. Firstly, they were classified into four groups based on their content and relations to the topics of analysis. Duplicate statements with similar ideas were then discarded in order to have one representative statement from each group. Some statements were simplified and edited for clarity, and some negative statements were changed to positive for convenience in interpretation. As shown in Table 9, a final Q-sample containing 27 structured statements were created and randomly numbered from 1 to 27 . 
[Table 9] Final Q-sample used for flood expert interviews

\begin{tabular}{|c|c|c|}
\hline Topics & No. & Statements \\
\hline \multirow{6}{*}{$A$} & 25 & $\begin{array}{l}\text { Flood inundation extent map (e.g., the FEMA 100-year floodplain map) is the } \\
\text { best indicator for assessing flood vulnerability. }\end{array}$ \\
\hline & 1 & $\begin{array}{l}\text { Successful flood risk management depends on the construction and } \\
\text { maintenance of levees, dikes, dams and other water infrastructures. }\end{array}$ \\
\hline & 18 & $\begin{array}{l}\text { The primary goal of flood mitigation is to relocate residents out of floodplains } \\
\text { and elevate buildings above the Base Flood Elevation (BFE). }\end{array}$ \\
\hline & 13 & $\begin{array}{l}\text { It is significant to understand differences in residents' socioeconomic capacity } \\
\text { to cope with flood risks. }\end{array}$ \\
\hline & 7 & $\begin{array}{l}\text { Flood mitigation policy and planning should be primarily focused on the } \\
\text { people who are poor, disabled, aged or cannot speak English. }\end{array}$ \\
\hline & 23 & $\begin{array}{l}\text { It is important to consider both physical and socioeconomic vulnerability to } \\
\text { flood risks. }\end{array}$ \\
\hline \multirow{9}{*}{ B } & 24 & $\begin{array}{l}\text { Both structural and nonstructural flood measures should be sustainable and } \\
\text { cost effective so they can help as many people as possible for as long as } \\
\text { possible. }\end{array}$ \\
\hline & 20 & $\begin{array}{l}\text { The city budget should be primarily spent on public services that can create } \\
\text { the greatest benefits for the majority. }\end{array}$ \\
\hline & 12 & $\begin{array}{l}\text { From an efficiency standpoint, the Willing Seller Land Acquisition Program is a } \\
\text { great way to reduce flood risks and the potential financial burden from flood } \\
\text { damage. }\end{array}$ \\
\hline & 6 & $\begin{array}{l}\text { Since political power tends to be asymmetrical, adaptive actions for potential } \\
\text { flood risks can reduce the vulnerability of only those best placed to take } \\
\text { advantage of governance institutions rather than reduce the vulnerability of } \\
\text { minority and disempowered populations. }\end{array}$ \\
\hline & 3 & $\begin{array}{l}\text { All community members should have equal access to adequate information, } \\
\text { resources and emergency services during flood disasters. }\end{array}$ \\
\hline & 17 & $\begin{array}{l}\text { In flood policy development and implementation, social and economic } \\
\text { inequalities can be allowed by justice when such inequalities work to the } \\
\text { benefit of the least advantaged members of communities. }\end{array}$ \\
\hline & 9 & $\begin{array}{l}\text { In flood risk management, environmental justice means taking shared } \\
\text { responsibility for promoting human rights of socioeconomically disadvantaged } \\
\text { groups in communities. }\end{array}$ \\
\hline & 5 & $\begin{array}{l}\text { Individual property rights can be compromised or sacrificed for other } \\
\text { community member's rights to be safeguarded from floods and other natural } \\
\text { disasters. }\end{array}$ \\
\hline & 15 & $\begin{array}{l}\text { The protection of human rights should not be optional in flood risk } \\
\text { management. }\end{array}$ \\
\hline \multirow{3}{*}{ C } & 8 & $\begin{array}{l}\text { As a social dispensation, reducing socioeconomic vulnerability of people needs } \\
\text { to be discussed and achieved mainly through non-governmental organizations } \\
\text { and intermediate groups. }\end{array}$ \\
\hline & 19 & $\begin{array}{l}\text { It is not only institutional but also individual responsibility to increase abilities } \\
\text { to better cope with flood disasters. }\end{array}$ \\
\hline & 14 & $\begin{array}{l}\text { Local government should focus on providing education that helps community } \\
\text { members increase their own capacity to withstand flood risks and reduce }\end{array}$ \\
\hline
\end{tabular}




\begin{tabular}{|c|c|c|}
\hline & & economic losses. \\
\hline & 27 & $\begin{array}{l}\text { Flood insurance is not a responsible policy because it does not reduce the } \\
\text { damages and merely spreads the monetary loss over a wider population } \\
\text { sector. }\end{array}$ \\
\hline & 10 & $\begin{array}{l}\text { In situations of flood disasters, government has moral obligation to provide } \\
\text { humanitarian assistance especially for socioeconomically disadvantaged } \\
\text { populations. }\end{array}$ \\
\hline & 26 & $\begin{array}{l}\text { Flooding is a city-wide problem that requires comprehensive, diversified and } \\
\text { systematic city-wide solutions. }\end{array}$ \\
\hline \multirow{6}{*}{$\mathrm{D}$} & 4 & $\begin{array}{l}\text { Hydraulic or hydrologic analysis should be taken into account as the most } \\
\text { valuable source in flood mitigation planning. }\end{array}$ \\
\hline & 11 & $\begin{array}{l}\text { Successful flood mitigation planning largely depends on the ability and } \\
\text { competence of flood experts and practitioners. }\end{array}$ \\
\hline & 22 & $\begin{array}{l}\text { Government should put more efforts on enhancing technological capability to } \\
\text { simulate and predict floods. }\end{array}$ \\
\hline & 16 & $\begin{array}{l}\text { In the process of developing flood mitigation strategies, local residents' } \\
\text { opinions should be considered prior to flood experts' opinions. }\end{array}$ \\
\hline & 2 & $\begin{array}{l}\text { Local knowledge should be a foundation to public policy in flood risk reduction } \\
\text { and management. }\end{array}$ \\
\hline & 21 & $\begin{array}{l}\text { For successful flood risk management, it is essential to enhance public } \\
\text { engagement through more direct and participatory decision-making } \\
\text { mechanisms. }\end{array}$ \\
\hline
\end{tabular}

\section{2) Q-Sorting Process}

Q-methodology is primarily concerned with intra-individual differences in significance rather than inter-individual differences. For this reason, the method is not restricted by sample size, and in fact, follows the small-sample theory (Kim, 2017). The number of participants does not generate the study's statistical power in Qmethodology and only the number of statements is used for significance testing (Militello and Benham, 2010). In Q-methodology, it is more critical to capture the range of perspectives and information from individuals with expertise and knowledge related to the research topic (Watts \& Stenner, 2012; Simons, 2013; Kamal et. al, 2014). In order to obtain a broad range of responses, interview participants were selected from a variety of bureaus, agencies and institutes in the City of Portland including Johnson Creek 
Watershed Council (JCWC), Bureau of Environmental Services (BES), Bureau of Planning and Sustainability (BPS), Bureau of Emergency Management, Portland Park and Recreation, Portland Housing Bureau, Multnomah County, Multnomah County Drainage District (MCDD), and Portland State University. As shown in Table 10, a total of 15 flood experts and urban practitioners were recruited through snowball sampling, and individually interviewed from March 21 to May 29, 2018. The one-to-one interviews were conducted in order to guarantee the quality of Q-sorting data by collecting information directly from the participants. 
[Table 10] Overview of interview participants

\begin{tabular}{|c|c|c|c|}
\hline ID No. & Affiliation & Position & Date \\
\hline 1 & Portland State University & Hydraulic Engineer & 2018.3.21 \\
\hline 2 & Portland State University & Professor & 2018.3.23 \\
\hline 3 & Johnson Creek Watershed Council & Executive Director & 2018.3 .29 \\
\hline 4 & Portland Bureau of Environmental Services & $\begin{array}{l}\text { Environmental Services } \\
\text { Staff }\end{array}$ & 2018.3.30 \\
\hline 5 & Portland Bureau of Environmental Services & $\begin{array}{c}\text { Environmental } \\
\text { Program Coordinator }\end{array}$ & 2018.3.30 \\
\hline 6 & Portland Bureau of Environmental Services & $\begin{array}{c}\text { Environmental } \\
\text { Program Coordinator }\end{array}$ & 2018.4.03 \\
\hline 7 & Portland Bureau of Parks and Recreation & $\begin{array}{l}\text { Natural Resources } \\
\text { Planner }\end{array}$ & 2018.4.06 \\
\hline 8 & $\begin{array}{l}\text { Portland Bureau of Planning and } \\
\text { Sustainability }\end{array}$ & $\begin{array}{c}\text { Climate Action Program } \\
\text { Manager }\end{array}$ & 2018.4.11 \\
\hline 9 & Portland Housing Bureau & $\begin{array}{l}\text { Housing Program } \\
\text { Coordinator }\end{array}$ & 2018.4.12 \\
\hline 10 & Portland Bureau of Environmental Services & $\begin{array}{l}\text { Eastside Watershed } \\
\text { Program Manager }\end{array}$ & 2018.4.19 \\
\hline 11 & Portland Bureau of Environmental Services & $\begin{array}{l}\text { Regulatory and Policy } \\
\text { Analyst }\end{array}$ & 2018.4.19 \\
\hline 12 & Portland Bureau of Emergency Management & $\begin{array}{l}\text { Disaster Resilience } \\
\text { Planner }\end{array}$ & 2018.4.25 \\
\hline 13 & Multnomah County Drainage District & Project Manager & 2018.5.04 \\
\hline 14 & $\begin{array}{l}\text { Multnomah County Office of Emergency } \\
\text { Management }\end{array}$ & Senior Equity Planner & 2018.5.15 \\
\hline 15 & Multnomah County Office of Sustainability & Senior Policy Analyst & 2018.5.29 \\
\hline
\end{tabular}

At the beginning of interview, each participant was fully informed about the purpose and procedures of Q-methodology and the confidentiality and anonymity of their individual responses. During the interview, participants were then asked to arrange 27 statements printed on $12 \mathrm{~cm} \times 8 \mathrm{~cm}$ cards into nine categories. Participants recorded their sorting results on an answer sheet containing a grid with headings ranging from -4 (least important or least agree) on the left side to +4 (most important or most agree) on the right side. In this analysis, the ' 0 ' middle point may represent not only neutrality but also respondent's indifference or irrelevance to the statement. As illustrated in Figure 10, 
participants were asked to place cards onto a normal distribution shaped grid, which allows fewer statements to represent the respondents' extreme opinions. Following the completion of the Q-sorting process, a post-sort interview was conducted with each respondent to investigate their understanding of the process and reasoning behind the sorting statements the way they did. All participants were asked about their ordering of two extreme statements (-4 and 4 ) to ensure an accurate interpretation of the Q-factors. As shown in Q-factor analysis section, participants' verbal information provided the important rationale in understanding statistical findings and defining discourses of flood risk and environmental justice.

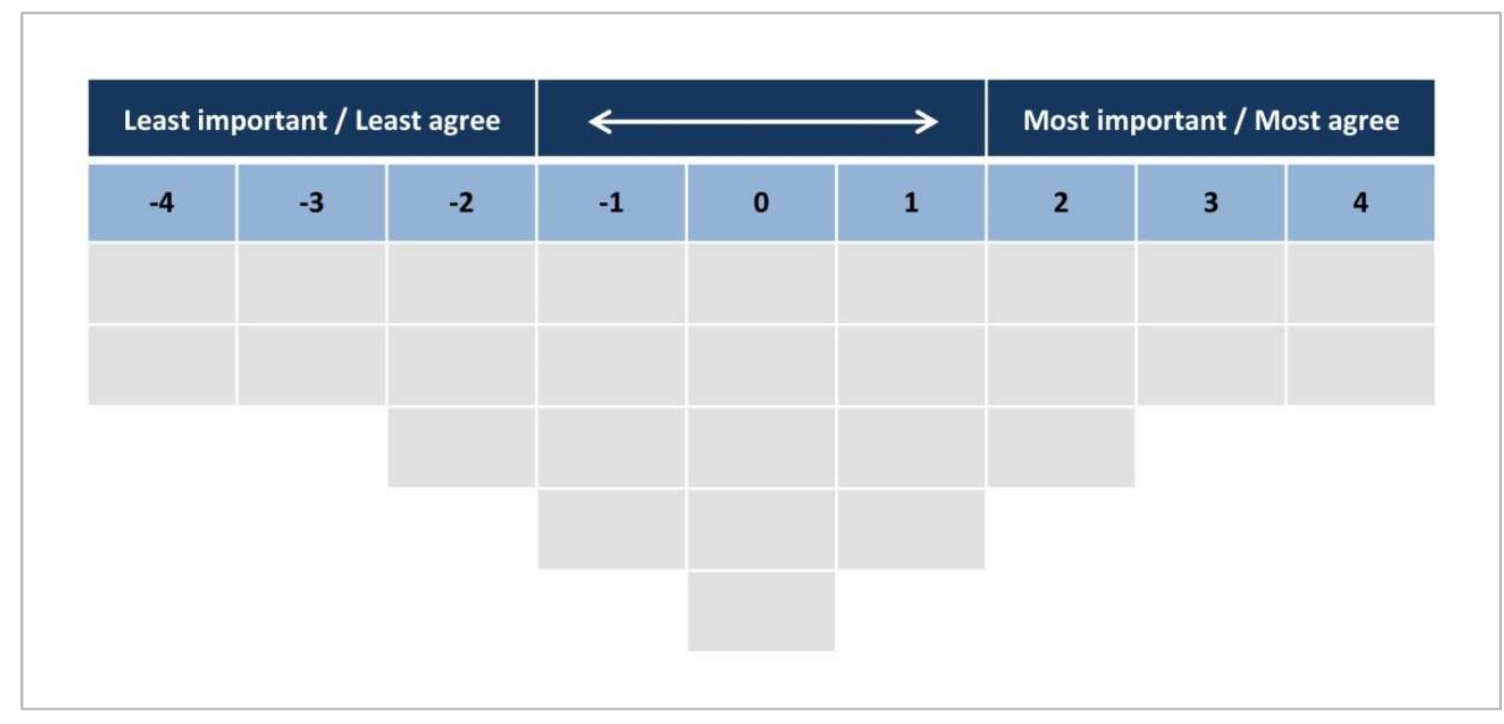

[Figure 10] Q-sorting matrix

\section{3) Q-Factor Analysis}

The 15 retained Q-sorts were analyzed using PQMethod (Version 2.35) 
software ${ }^{11}$. This study performed principal components analysis on the correlations among the participants' Q-sorts and the resulting factors were rotated orthogonally using varimax rotation. In Q-methodology, the correlates are participants, the resulting factors represent point of view, and an individual participant's loadings on each factor indicates his or her level of agreement with the holistic point of view encapsulated by the specific factor (Beckham Hooff et al., 2017). As shown in Table 11, the Q-factor analysis of flood experts' perception on flood risk and environmental justice yielded three distinct points of view, which explained $81 \%$ of the total variance including Factor $1(44 \%)$, Factor $2(25 \%)$ and Factor $3(11 \%)$. The eigenvalue was 6.66, 3.81 and 1.62, respectively. The correlations of three factors indicated a degree of similarity among them, but they were still relatively independent.

[Table 11] Descriptive statics of Q-factors

Eigenvalues, Variance and Cumulative variance

$$
\mathrm{N}=15
$$

\begin{tabular}{c|c|c|c}
\hline & Factor 1 & Factor 2 & Factor 3 \\
\hline \hline Eigenvalue & 6.6641 & 3.8133 & 1.6222 \\
\hline Variance (\%) & 44 & 25 & 11 \\
\hline Cumulative variance (\%) & 44 & 70 & 81 \\
\hline
\end{tabular}

\begin{tabular}{c|c|c|c}
\multicolumn{1}{l}{ Correlation Matrix } & $\mathrm{N}=15$ \\
\hline & Factor 1 & Factor 2 & Factor 3 \\
\hline \hline Factor 1 & 1.0000 & - & - \\
\hline Factor 2 & 0.4366 & 1.0000 & - \\
\hline Factor 3 & -0.0815 & 0.3664 & 1.0000 \\
\hline
\end{tabular}

11 PQMethod is a freeware statistical program tailored to the requirements of $Q$ studies. The program and manual are available at http://schmolck.userweb.mwn.de/qmethod. 
The factor loadings of each participant are shown in Table 12. For factor loadings, the higher the value for a factor, the more a participant exhibits the typical characteristics of that factor. In this study, six people belonged to Factor 1, five to Factor 2 , and four to Factor 3. To analyze the features of factors, this study determined which of the 27 statements participants of each factor exhibited strong agreement (Z-score +1 or greater) and strong disagreement (Z-score -1 or less) with.

[Table 12] Participants loading on factors after varimax rotation

$(*)$ indicates a defining sort

\begin{tabular}{c|c|c|c}
\hline Q-sorting No. & Factor 1 & Factor 2 & Factor 3 \\
\hline 1 & -0.1931 & 0.2176 & $0.9023^{*}$ \\
\hline 2 & $0.7940^{*}$ & 0.3693 & 0.1195 \\
\hline 3 & $0.7420^{*}$ & 0.2864 & -0.0804 \\
\hline 4 & 0.1210 & 0.1591 & $0.7786^{*}$ \\
\hline 5 & $0.6571^{*}$ & 0.2046 & -0.1552 \\
\hline 6 & -0.0517 & 0.1513 & $0.9714^{*}$ \\
\hline 7 & $0.8537^{*}$ & 0.1994 & 0.0013 \\
\hline 8 & 0.2755 & $0.9287^{*}$ & 0.2104 \\
\hline 9 & -0.1749 & 0.2621 & $0.8760^{*}$ \\
\hline 10 & 0.4589 & $0.6861^{*}$ & 0.2833 \\
\hline 11 & 0.1680 & $0.8005^{*}$ & 0.3527 \\
\hline 12 & $0.9030^{*}$ & 0.1095 & -0.0125 \\
\hline 13 & $0.8942^{*}$ & 0.1089 & -0.1183 \\
\hline 14 & 0.1982 & $0.9167^{*}$ & 0.1345 \\
\hline 15 & 0.3059 & $0.9064^{*}$ & 0.1705 \\
\hline Number of participants & 6 & 5 & 4 \\
\hline Explained variance (\%) & 30 & 27 & 23 \\
\hline
\end{tabular}

The Q-sorting number in this table is not the same as the ID number assigned in Table 10.

Factor 1: Human Rights Promoters

Factor 1 accounts for $30 \%$ of the variance in responses, and six of the 15 
participants (40\%) had a high level of agreement with the array of statements for this factor. Factor 1 respondents' selection of statements focused on the value of human rights and active institutional responsibility, suggesting that environmental justice should be fulfilled in flood mitigation policy and planning as a means to promote human rights of socioeconomically vulnerable groups. Stemming from their positive support for individual's basic rights to be safeguarded from flood risks, the respondents in this factor are nicknamed 'Human Rights Promoters'. 
[Table 13] Strongly agree and strongly disagree statements for Factor 1

\begin{tabular}{c|l|c}
\hline No. & \multicolumn{1}{|c}{ Statements } & Z-scores \\
\hline \hline 21 & $\begin{array}{l}\text { For successful flood risk management, it is essential to enhance public } \\
\text { engagement through more direct, participatory decision-making } \\
\text { mechanisms. }\end{array}$ & 1.791 \\
\hline 10 & $\begin{array}{l}\text { In situations of flood disasters, government has a moral obligation to } \\
\text { provide humanitarian assistance especially for socioeconomically } \\
\text { disadvantaged populations. }\end{array}$ & 1.269 \\
\hline 15 & $\begin{array}{l}\text { The protection of human rights should not be optional in flood risk } \\
\text { management. }\end{array}$ & 1.231 \\
\hline 26 & $\begin{array}{l}\text { Flooding is a city-wide problem that requires comprehensive, diversified and } \\
\text { systematic city-wide solutions. }\end{array}$ & 1.220 \\
\hline 9 & $\begin{array}{l}\text { In flood risk management, environmental justice means taking shared } \\
\text { responsibility for promoting human rights of socioeconomically } \\
\text { disadvantaged groups in communities. }\end{array}$ & 1.168 \\
\hline 13 & $\begin{array}{l}\text { It is significant to understand differences in residents' socioeconomic } \\
\text { capacity to cope with flood risks. }\end{array}$ & 1.036 \\
\hline 22 & $\begin{array}{l}\text { Government should put more efforts on enhancing technological capability } \\
\text { to simulate and predict floods. }\end{array}$ & -1.025 \\
\hline 11 & $\begin{array}{l}\text { Successful flood mitigation planning largely depends on the ability and } \\
\text { competence of flood experts and practitioners. }\end{array}$ & -1.295 \\
\hline 8 & $\begin{array}{l}\text { As a social dispensation, reducing socioeconomic vulnerability of people } \\
\text { needs to be discussed and achieved mainly through non-governmental } \\
\text { organizations and intermediate groups. }\end{array}$ & $\begin{array}{l}\text { Successful flood risk management depends on the construction and } \\
\text { maintenance of levees, dikes, dams and other water infrastructures. }\end{array}$ \\
\hline 25 & $\begin{array}{l}\text { Flood inundation extent map (e.g., the FEMA 100-year floodplain map) is } \\
\text { the best indicator for assessing flood vulnerability. }\end{array}$ & $\begin{array}{l}\text { Hydraulic analysis should be taken into account as the most valuable source } \\
\text { in flood mitigation planning. }\end{array}$ \\
\hline
\end{tabular}

As presented in Table 13, Factor 1 respondents had showed strong agreement on the statement 15 which advocates human rights as inviolable natural rights as well as statements 9 and 10 which emphasize institutional responsibility to provide humanitarian assistance for those socioeconomically vulnerable to current and future flood risks. In a similar sense, respondents strongly disagreed upon that helping socioeconomically vulnerable populations is a social dispensation which should be 
achieved mainly through non-governmental organizations and intermediate groups (statement 8). In addition, Factor 1 respondent perceived floods as a city-wide problem that requires comprehensive and systematic solutions (statement 26 ), and pointed out the importance of understanding differences in residents' socioeconomic capacity to cope with flood risks (statement 13). For this, respondents strongly supported public engagement and participatory decision-making (statement 21), and showed negative attitudes toward expert-driven (statement 11), science and technology-based (statement 4, 22, 25), and fully structural (statement 1) approaches. Distinguishing statements that characterize Factor 1 are as follows. 
[Table 14] Distinguishing statements for Factor 1

\begin{tabular}{|c|c|c|c|c|}
\hline \multirow{2}{*}{ No. } & \multirow{2}{*}{ Statements } & Factor 1 & Factor 2 & Factor 3 \\
\hline & & Z-scores & Z-scores & Z-scores \\
\hline 10 & $\begin{array}{l}\text { In situations of flood disasters, government has a moral obligation to provide humanitarian assistance } \\
\text { especially for socioeconomically disadvantaged populations. }\end{array}$ & $1.27^{*}$ & -0.59 & -0.21 \\
\hline 15 & The protection of human rights should not be optional in flood risk management. & $1.23^{*}$ & -0.40 & -0.78 \\
\hline 9 & $\begin{array}{l}\text { In flood risk management, environmental justice means taking shared responsibility for promoting } \\
\text { human rights of socioeconomically disadvantaged groups in communities. }\end{array}$ & $1.17^{*}$ & -0.44 & -0.14 \\
\hline 13 & It is significant to understand differences in residents' socioeconomic capacity to cope with flood risks. & $1.04^{*}$ & 0.00 & 0.00 \\
\hline 7 & $\begin{array}{l}\text { Flood mitigation policy and planning should be primarily focused on the people who are poor, disabled, } \\
\text { aged or cannot speak English. }\end{array}$ & 0.67 & 0.00 & -0.38 \\
\hline 3 & $\begin{array}{l}\text { All community members should have equal access to adequate information, resources and emergency } \\
\text { services during flood disasters. }\end{array}$ & 0.61 & 1.56 & -0.19 \\
\hline 6 & $\begin{array}{l}\text { Since political power tends to be asymmetrical, adaptive actions for potential flood risks can reduce the } \\
\text { vulnerability of only those best placed to take advantage of governance institutions rather than reduce } \\
\text { the vulnerability of disempowered populations. }\end{array}$ & $0.32 *$ & -1.04 & -1.81 \\
\hline 27 & $\begin{array}{l}\text { Flood insurance is not a responsible policy because it does not reduce the damages but merely spreads } \\
\text { the monetary loss over a wider population sector. }\end{array}$ & $0.16^{*}$ & -0.70 & -0.99 \\
\hline 24 & $\begin{array}{l}\text { Both structural and nonstructural flood measures should be sustainable and cost effective so they can } \\
\text { help as many people as possible for as long as possible. }\end{array}$ & 0.02 & 0.64 & 1.43 \\
\hline 16 & $\begin{array}{l}\text { In the process of developing flood mitigation strategies, local residents' opinions should be considered } \\
\text { prior to flood experts' opinions. }\end{array}$ & -0.06 & -0.71 & -1.26 \\
\hline 19 & $\begin{array}{l}\text { It is not only institutional but also individual responsibility to increase abilities to better cope with flood } \\
\text { disasters. }\end{array}$ & $-0.36^{*}$ & 0.51 & 0.72 \\
\hline 20 & $\begin{array}{l}\text { The city budget should be primarily spent on public services that can create the greatest benefits for the } \\
\text { majority. }\end{array}$ & $-0.61^{*}$ & 1.23 & 0.44 \\
\hline 11 & $\begin{array}{l}\text { Successful flood mitigation planning largely depends on the ability and competence of flood experts and } \\
\text { practitioners. }\end{array}$ & $-1.29 *$ & 1.11 & 1.81 \\
\hline 8 & $\begin{array}{l}\text { As a social dispensation, reducing socioeconomic vulnerability of people needs to be discussed and } \\
\text { achieved mainly through non-governmental organizations and intermediate groups. }\end{array}$ & $-1.44^{*}$ & -0.19 & -0.03 \\
\hline
\end{tabular}

Distinguishing statements at a significance level of $95 \%(p<0.05)$.

$(*)$ indicates distinguishing statements at a significance level of $99 \%(p<0.01)$. 


\section{Factor 2: Public Benefits Bureaucrats}

Five out of 15 participants (33\%) loaded onto the perspective represented by Factor 2 with explained variance of $27 \%$. Factor 2 respondents' selection of statements is mainly related with the role of flood experts in ensuring public engagement and education, suggesting that environmental justice in flood risk management can be achieved through flood experts' efforts to enhance community's ability to cope with flood risks. Stemming from their focus on public interest as a goal of participatory decision-making, respondents in this factor are nicknamed 'Public Benefits Bureaucrats'.

As shown in Table 15, Factor 2 respondents also agreed upon that traditional science and technology-based (statement 4, 22, 25) and fully structural (statement 1) approaches are not suitable to address both physical and socioeconomic flood vulnerability of communities (statements 23). However, unlike Factor 1, respondents in this factor strongly emphasized the ability and competence of flood experts (statement 11) in improving the substantive quality of decision-making by increasing public participation (statement 21), and informing and educating the public (statement 14). 
[Table 15] Strongly agree and strongly disagree statements for Factor 2

\begin{tabular}{c|l|c}
\hline No. & \multicolumn{1}{|c}{ Statements } & Z-scores \\
\hline \hline 21 & $\begin{array}{l}\text { For successful flood risk management, it is essential to enhance public } \\
\text { engagement through more direct, participatory decision-making } \\
\text { mechanisms. }\end{array}$ & 1.735 \\
\hline 3 & $\begin{array}{l}\text { All community members should have equal access to adequate information, } \\
\text { resources and emergency services during flood disasters. }\end{array}$ & 1.560 \\
\hline 23 & $\begin{array}{l}\text { It is important to consider both physical and socioeconomic vulnerability to } \\
\text { flood risks. }\end{array}$ & 1.313 \\
\hline 20 & $\begin{array}{l}\text { The city budget should be primarily spent on public services that can create } \\
\text { the greatest benefits for the majority. }\end{array}$ & 1.234 \\
\hline 14 & $\begin{array}{l}\text { Local government should focus on providing education that helps } \\
\text { community members increase their own capacity to withstand flood risks } \\
\text { and reduce economic losses. }\end{array}$ & 1.157 \\
\hline 11 & $\begin{array}{l}\text { Successful flood mitigation planning largely depends on the ability and } \\
\text { competence of flood experts and practitioners. }\end{array}$ & 1.113 \\
\hline 6 & $\begin{array}{l}\text { Since political power tends to be asymmetrical, adaptive actions for } \\
\text { potential flood risks can reduce the vulnerability of only those best placed to } \\
\text { take advantage of governance institutions rather than reduce the } \\
\text { vulnerability of disempowered populations. }\end{array}$ & -1.043 \\
\hline 1 & $\begin{array}{l}\text { Successful flood risk management depends on the construction and } \\
\text { maintenance of levees, dikes, dams and other water infrastructures. }\end{array}$ & -1.721 \\
\hline 22 & $\begin{array}{l}\text { Government should put more efforts on enhancing technological capability } \\
\text { to simulate and predict floods. }\end{array}$ & $\begin{array}{l}\text { Hydraulic analysis should be taken into account as the most valuable source } \\
\text { in flood mitigation planning. }\end{array}$ \\
\hline the best indicator for assessing flood vulnerability. & -1.529 \\
\hline
\end{tabular}

The important thing to point out is that Factor 2 respondents ironically held a passive and skeptical attitude toward government's rights-based approaches despite of their high concerns about individual difference in needs and abilities. Throughout the interviews, Factor 2 respondents shared their opinions that humanitarian aids do not help community members to increase their own capacity to withstand flood risks, and thus, may not yield anything other than alleviating the situation. From a utilitarian standpoint, Factor 2 respondents also asserted that government's supports for 
socioeconomically vulnerable populations can be limited because the city budget should be primarily spent on public services that can create benefits for the majority (statement 20). In a similar sense, they expressed strong or moderated disagreement on statement 6 about the possibility of unbalanced and unfair policy with the reason that there is no best policy for every individual situation, and public policy should prioritize the public good over the private interest. Additionally, two out of five respondents mentioned that moral obligation is owed to society, not to government, suggesting that, helping the vulnerable should be rooted in social consensus rather than political considerations. Followings are distinguishing statements that differentiate Factor 2 from the other factors. 
[Table 16] Distinguishing statements for Factor 2

\begin{tabular}{c|l|c|c|c}
\hline \multirow{2}{*}{ No. } & \multicolumn{1}{|c|}{ Statements } & Factor 1 & Factor 2 & Factor 3 \\
\cline { 3 - 5 } 3 & Z-scores & Z-scores & Z-scores \\
\hline \hline 20 & $\begin{array}{l}\text { All community members should have equal access to } \\
\text { adequate information, resources and emergency } \\
\text { services during flood disasters. }\end{array}$ & 0.61 & $1.56^{*}$ & -0.19 \\
\hline \multirow{2}{*}{211} & $\begin{array}{l}\text { The city budget should be primarily spent on public } \\
\text { services that can create the greatest benefits for the } \\
\text { majority. }\end{array}$ & -0.61 & 1.23 & 0.44 \\
\hline $\begin{array}{l}\text { Successful flood mitigation planning largely depends } \\
\text { on the ability and competence of flood experts and } \\
\text { practitioners. }\end{array}$ & -1.29 & 1.11 & 1.81 \\
\hline $\begin{array}{l}\text { Both structural and nonstructural flood measures } \\
\text { should be sustainable and cost effective so they can } \\
\text { help as many people as possible for as long as possible. }\end{array}$ & 0.02 & 0.64 & 1.43 \\
\hline 26 & $\begin{array}{l}\text { Flooding is a city-wide problem that requires } \\
\text { comprehensive, diversified and systematic city-wide } \\
\text { solutions. }\end{array}$ & 1.22 & 0.57 & 1.48 \\
\hline & $\begin{array}{l}\text { Since political power tends to be asymmetrical, } \\
\text { adaptive actions for potential flood risks can reduce } \\
\text { the vulnerability of only those best placed to take } \\
\text { advantage of governance institutions rather than } \\
\text { reduce the vulnerability of disempowered populations. }\end{array}$ & 0.32 & -1.04 & -1.81 \\
\hline
\end{tabular}

Distinguishing statements at a significance level of $95 \%(p<0.05)$.

$\left({ }^{*}\right)$ indicates distinguishing statements at a significance level of $99 \%(p<0.01)$.

Factor 3: Technology Advocates

Factor 3 accounts for $23 \%$ of variance in responses and three of the 15 participants (20\%) had a high level of agreement with the array of statements for this factor. The respondents characterizing Factor 3 focused on scientific knowledge and information in decision-making, suggesting that, accurate prediction and mapping of floods should be the basis of flood policy development and implementation. These respondents emphasized flood experts' ability to utilize the results of water science and engineering analysis in order to enumerate all possible scenarios of flood disaster, and they are thus nicknamed 'Technology Advocates'. 
[Table 17] Strongly agree and strongly disagree statements for Factor 3

\begin{tabular}{|c|c|c|}
\hline No. & Statements & Z-scores \\
\hline 11 & $\begin{array}{l}\text { Successful flood mitigation planning largely depends on the ability and } \\
\text { competence of flood experts and practitioners. }\end{array}$ & 1.813 \\
\hline 26 & $\begin{array}{l}\text { Flooding is a city-wide problem that requires comprehensive, diversified and } \\
\text { systematic city-wide solutions. }\end{array}$ & 1.479 \\
\hline 24 & $\begin{array}{l}\text { Both structural and nonstructural flood measures should be sustainable and } \\
\text { cost effective so they can help as many people as possible for as long as } \\
\text { possible. }\end{array}$ & 1.432 \\
\hline 4 & $\begin{array}{l}\text { Hydraulic analysis should be taken into account as the most valuable source } \\
\text { in flood mitigation planning. }\end{array}$ & 1.385 \\
\hline 23 & $\begin{array}{l}\text { It is important to consider both physical and socioeconomic vulnerability to } \\
\text { flood risks. }\end{array}$ & 1.015 \\
\hline 16 & $\begin{array}{l}\text { In the process of developing flood mitigation strategies, local residents' } \\
\text { opinions should be considered prior to flood experts' opinions. }\end{array}$ & -1.260 \\
\hline 1 & $\begin{array}{l}\text { Successful flood risk management depends on the construction and } \\
\text { maintenance of levees, dikes, dams and other water infrastructures. }\end{array}$ & -1.498 \\
\hline 25 & $\begin{array}{l}\text { Flood inundation extent map (e.g., the FEMA } 100 \text {-year floodplain map) is } \\
\text { the best indicator for assessing flood vulnerability. }\end{array}$ & -1.766 \\
\hline 6 & $\begin{array}{l}\text { Since political power tends to be asymmetrical, adaptive actions for } \\
\text { potential flood risks can reduce the vulnerability of only those best placed to } \\
\text { take advantage of governance institutions rather than reduce the } \\
\text { vulnerability of disempowered populations. }\end{array}$ & -1.813 \\
\hline
\end{tabular}

Technology Advocates are distinguished from other factors by their general support for technical expertise and practical experience, and less concern about the issues of environmental justice and human rights. A clear-cut example of their emphasis on science and technology-based approaches is demonstrated by statements 4,11 and 16 about the importance of hydraulic data as a foundation of rational decision-making, and the capacity of experts to utilize it to improve the situation. High negative z-scores of statement 1 and 25 are difficult to be understood as an objection against technical approaches because the disagreement is based on their professional opinions that flood structures should be more improved in a way to enhance ecosystem functions, and 
FEMA floodplain maps are required to be updated to reflect existing land use and development conditions. Factor 3 respondents asserted that rational decision should not only be reasoned, but also optimal for solving problems. For this reason, they placed value on the sustainability and cost-effectiveness of flood measures in order to benefit as many people as possible for as long as possible (statement 24). Factor 3 respondents generally perceived flood disasters as a complex city-wide problem (statement 26), and were aware of the importance of holistic approach to reduce both physical and socioeconomic flood vulnerability. However, no statements about human rights, environmental justice, public participation and institutional responsibility were identified as consensus statements across the viewpoints. Additionally, Technology Advocates showed similar opinions with Factor 2 respondents on statement 6 that there is no best policy for every individual situation, and it is appropriate to choose policies for the majority when value conflicts arise during the decision-making process. Distinguishing statements that characterize Factor 3 are as follows. 
[Table 18] Distinguishing statements for Factor 3

\begin{tabular}{|c|c|c|c|c|}
\hline \multirow{2}{*}{ No. } & \multirow{2}{*}{ Statements } & Factor 1 & Factor 2 & Factor 3 \\
\hline & & Z-scores & Z-scores & Z-scores \\
\hline 11 & $\begin{array}{l}\text { Successful flood mitigation planning largely depends } \\
\text { on the ability and competence of flood experts and } \\
\text { practitioners. }\end{array}$ & -1.29 & 1.11 & 1.81 \\
\hline 24 & $\begin{array}{l}\text { Both structural and nonstructural flood measures } \\
\text { should be sustainable and cost effective so they can } \\
\text { help as many people as possible for as long as } \\
\text { possible. }\end{array}$ & 0.02 & 0.64 & 1.43 \\
\hline 4 & $\begin{array}{l}\text { Hydraulic analysis should be taken into account as the } \\
\text { most valuable source in flood mitigation planning. }\end{array}$ & -1.62 & -1.66 & $1.38^{*}$ \\
\hline 22 & $\begin{array}{l}\text { Government should put more efforts on enhancing } \\
\text { technological capability to simulate and predict floods. }\end{array}$ & -1.03 & -1.53 & $0.89 *$ \\
\hline 18 & $\begin{array}{l}\text { The primary goal of flood mitigation is to relocate } \\
\text { residents out of floodplains. }\end{array}$ & -0.71 & -0.92 & $0.56^{*}$ \\
\hline 20 & $\begin{array}{l}\text { The city budget should be primarily spent on public } \\
\text { services that can create the greatest benefits for the } \\
\text { majority. }\end{array}$ & -0.61 & 1.23 & 0.44 \\
\hline 3 & $\begin{array}{l}\text { All community members should have equal access to } \\
\text { adequate information, resources and emergency } \\
\text { services during flood disasters. }\end{array}$ & 0.61 & 1.56 & -0.19 \\
\hline 21 & $\begin{array}{l}\text { For successful flood risk management, it is essential to } \\
\text { enhance public engagement through more direct, } \\
\text { participatory decision-making mechanisms. }\end{array}$ & 1.79 & 1.74 & $-0.51^{*}$ \\
\hline 2 & $\begin{array}{l}\text { Local knowledge should be a foundation to public } \\
\text { policy in flood risk reduction and management. }\end{array}$ & 0.54 & 0.84 & $-0.82^{*}$ \\
\hline 6 & $\begin{array}{l}\text { Since political power tends to be asymmetrical, } \\
\text { adaptive actions for potential flood risks can reduce } \\
\text { the vulnerability of only those best placed to take } \\
\text { advantage of governance institutions rather than } \\
\text { reduce the vulnerability of disempowered } \\
\text { populations. }\end{array}$ & 0.32 & -1.04 & -1.81 \\
\hline
\end{tabular}

Distinguishing statements at a significance level of $95 \%(p<0.05)$.

$\left({ }^{*}\right)$ indicates distinguishing statements at a significance level of $99 \%(p<0.01)$.

As indicated in Table 19, it was found that all three groups of respondents were against structural approaches that are mainly focused only on the physical aspect of flood vulnerability. Basically, all respondents agreed that there are many environmental and ecological variables that traditional hard engineering measures cannot address or 
control. It seems noticeable that Technology Advocates who emphasized the importance of technical advance in reducing flood risks also showed similar opinions that current schemes are required to be replaced to soft engineering approaches which work in harmony with natural processes rather than against them. However, regarding the statement 25, while Technology Advocates' concerns were mainly limited on the inaccuracy and unreliability of FEMA floodplain maps, both Human Rights Promoters' and Public Benefits Bureaucrats' concerns were extended to the heavy reliance of current flood risk management on FEMA floodplain maps and the possibility of overlooking the true local character of communities. More specifically, both Human Rights Promoters and Public Benefits Bureaucrats were distinguished from Technology Advocates in that they were clearly aware that there exist spatial differences between physically vulnerable areas and socioeconomically vulnerable areas, and thus, outdated and over-simplistic scientific data can mislead actual flood mitigation practices unless accompanied by special efforts to address socioeconomic factors that lower the ability of people and communities to adapt to flood risks.

[Table 19] Consensus statements that do not distinguish between any pair of factors

\begin{tabular}{c|l|c|c|c}
\hline \multirow{2}{*}{ No. } & \multicolumn{1}{|c|}{ Statements } & Factor 1 & Factor 2 & Factor 3 \\
\cline { 3 - 5 } & Z-scores & Z-scores & Z-scores \\
\hline \hline 1 & $\begin{array}{l}\text { Successful flood risk management depends on the } \\
\text { construction and maintenance of levees, dikes, dams } \\
\text { and other water infrastructures. }\end{array}$ & -1.51 & -1.10 & -1.50 \\
\hline 25 & $\begin{array}{l}\text { Flood inundation extent map (e.g., the FEMA 100-year } \\
\text { floodplain map) is the best indicator for assessing } \\
\text { flood vulnerability. }\end{array}$ & -1.61 & -1.72 & -1.77 \\
\hline
\end{tabular}

All listed statements are non-significant at $p>0.05$. 
Another important result to point out is that while Technology Advocates were less concerned about environmental justice, both Human Rights Promoters and Public Benefits Bureaucrats showed common agreement that socioeconomic inequality is one of the most important challenges, and flood risk management thus should be considered within the wider framework of the promotion of environmental justice. However, in spite of a consensus on the importance of environmental justice as a policy lever to reduce socioeconomic inequality, there were conspicuous differences between these two groups in the understanding of how this could be achieved. For Human Rights Promoters, socioeconomic inequality is a human rights problem that requires rightsbased interventions. They perceived that socioeconomic vulnerability is deeply rooted in a local, historical and political context; therefore, governmental institutions have an active obligation to provide financial, social and humanitarian supports. Most importantly, Human Rights Promoters asserted that environmental justice is not only a matter of providing information and resources to socioeconomically vulnerable populations, but also a matter of finding out and discussing what increases socioeconomic vulnerability and what prohibits us from overcoming environmental injustice. For this reason, Human Rights Promoters emphasized public participation as an opportunity to learn, network, and share ideas with others.

Meanwhile, it was revealed that Public Benefits Bureaucrats are skeptical against the Human Rights Promoters' perspective mainly with two reasons. Firstly, Public Benefits Bureaucrats perceived human rights as a personal value which can be limited or 
deprioritized for the enhancement of public interests. Public Benefits Bureaucrats thus focused on their role in addressing more efficient and impartial decisions in order to safeguard the best interest of the society as a whole. Secondly, Public Benefits Bureaucrats tended to view humanitarian assistance as a moral obligation which cannot be enforce by laws. For this reason, they tended to believe that rights-based approaches are intrinsically difficult to be promoted in an institutional context. For Public Benefits Bureaucrats, environment justice as an institutional responsibility thus should be promoted in a way that is consistent and complementary to general public goals and that is likely to be accepted across the society.

This analysis revealed that environmental justice perceived by three groups of flood experts are distinguished based on their different understandings of vulnerability, different interpretations of human rights, and different perspectives on the extent of institutional responsibility to assist socioeconomically vulnerable populations. Addressing these differences is not only theoretically meaningful but also practically important because the direction and priorities of natural disaster mitigation policy and planning can be changed depending on how governmental institutions incorporate these concepts into actual decision-making process. For this reason, the next chapter is devoted to addressing issues surrounding environmental justice discourses, and discussing the institutional aspect of vulnerability that may hamper environmental justice in ensuring human rights of socioeconomically vulnerable populations. 


\section{Discussion: Human Vulnerability and Human Rights in Natural Disaster Mitigation}

Overall, the findings of this study indicate that 1) current disaster policies and strategies are insufficient to cope with environmental justice issues that are raised in addressing different local situations and needs, 2) environmental justice can be addressed in different ways depending on which aspect of vulnerability we are considering, and how much we care about the socioeconomic vulnerability that is unfairly imposed on the certain group of people, and 3) the direction and priorities of natural disaster mitigation policy and planning can be changed depending on how governmental institutions understand and interpret a humanistic and pluralist concept of environmental justice.

The primary goal of this study was to address environmental justice in natural disaster mitigation policy and planning through the ideas of human vulnerability and human rights as a tool for challenging socioeconomic inequalities that can be caused by poverty and the lack of access to economic and political power in the public sphere. At this point, it is important to point out that Public Benefits Bureaucrats' arguments in previous analysis reside in misunderstanding of human rights. Human rights are normally distinguished into negative and positive rights. According to Wenz (1988), negative rights are rights to noninterference, rights not to be subjected to an action of another person or group (e.g., property rights, rights to privacy), and positive rights are rights to be given something, rights that can be achieved only when people provide assistance to one another rather than merely leave one another alone (e.g., rights to 
medical care, rights to minimal social assistance). Human rights as communal value are relevant to all members of society, not just those who face mistreatment or violation, and thus, promoting positive human rights is a way to advance public interests by imposing each individual's social, cultural and ideological beliefs on everyone. Both the theoretical and practical implications of positive human rights are significant especially in natural disaster mitigation because they provide the ethical and legal basis for institutional responsibility in assisting people who are vulnerable to uncontrollable risks of natural hazards through no fault of their own. From a critical pluralist point of view, it thus becomes important for governmental institutions to understand the particularity and difference of vulnerability conditions, and provide policy supports to promote basic human rights of disaster victims through comprehensive and inclusive governance mechanisms. As Aristotle defined, if justice is giving people what they deserve, it is environmentally unjust and not only morally and but also socially irresponsible to consider human rights merely as personal value and exclude certain groups of people from institutional supports.

Regarding the ambiguity of human rights as an institutional responsibility, Kant's theory of ethics provides a rationale for why human rights are important in the relationships between individuals and governmental institutions that have power over them. His 'Categorical Imperative' is a deontological ethical theory, which means we have a duty to act in certain ways. His idea of ethics stands out in clear contrast to the government exercises toward 'benefits for the majority rather than profits for the few' 
because of following primary principles: 1 ) Act as the universalized maxim ${ }^{12}$ requires, 2 ) never treat other human beings as a means to an end. For Kant, 'doing the right thing' is not determined by acting in pursuit of one's interest or desire, but acting in accordance with a maxim which all rational individuals are bound to accept (Nair, 2011). Human rights are rights we give to ourselves as formally equal beings, and the Categorical Imperative provides the basis for determining the scope and direction of public policies which rational, autonomous and self-conscious individuals should follow in order to promote and protect these very same conditions. From a Kantian perspective, government's actions are praiseworthy only when they are universalizable by conforming to the notion of human rights. Accordingly, governmental institutions should not deprioritize or exclude anyone's human rights for the benefits of majority, and publicly-beneficial policies should not require a few select individuals to bear the burdens of public benefits.

Clearly, the Public Benefits Bureaucrats' perspective based on utilitarianism and procedural egalitarianism show limitations in solving human rights problems that arise from the critical pluralist understanding of environmental justice. Addressing human rights problems in natural disaster mitigation means understanding impacts of natural disasters as the consequence of environmental injustice, not misfortune. A human rights-based approach in this respect yields totally different implications on resource distribution compared with a needs-based approach which governmental institutions

12 The maxim is the principle that moves the will to action. According to Kant, a maxim is a subjective principle of volition, not only as a personal policy but also as a principle for everyone. 
have followed in natural disaster mitigation policy and planning. One of the most noticeable differences is that a needs-based approach which arises from charitable intentions concerns how to secure additional resources to provide services to certain groups of people, while a human rights-based approach as moral and social obligations concerns how to share existing resources more equitably, and hence more justly, for assisting vulnerable populations to assert their own rights to those resources. From a needs-based perspective, it is thus natural for governmental institutions to focus on obtaining sufficient funds necessary to provide satisfactory services, and monitoring whether the money is properly used or not. This makes the process of needs-based approach to follow the utilitarian goal of maximum utility and to over-rely on costbenefit analysis and scientific data to give some validity to policy decisions.

A human rights-based approach, on the contrary, gives priority to more severe human rights violations even if these affect only a small number of people. One of the most important arguments of this study is that a human rights-based approach can make the natural disaster mitigation practice less political and less confrontational by prioritizing human rights as an indispensable universal value to understanding of how human beings should be treated by one another and by institutional and political bodies. From a Human Rights Promoters' standpoint, this argument provides an opportunity to refute the idea that environmental justice should be limited for the economic aspect of the common good, or environmental justice can be limited to the obligations of those who have superfluous resources. 
From a human rights perspective, disaster policy issues associated with environmental justice can be approached in a different way, with the emphasis on institutional responsibility for human vulnerability. In case of the Foster Floodplain Restoration Project, for example, a group of residents were asked to waive their rights to stay where they live for upholding the rest of community members' rights to be safeguarded from repeated flood risks. If we view this as the conflict between individual (negative) rights and social (positive) rights, institutional responsibility should be primarily focused on convincing why social rights should be promoted prior to individual rights, and explaining how to ensure appropriate compensation for the people who yield their rights. Until every stakeholder voluntarily agrees with the Willing Seller Land Acquisition plan, related governmental institutions thus should work to build consensus among community members whose rights must be considered, weighted and preserved, and ensure that the Foster Floodplain Restoration can improve both physical and socioeconomic vulnerability conditions of people whose rights are sacrificed as well.

The situation becomes more complex and problematic when the conflict between individual and social rights is expected but not clearly recognized before a disaster occurs. Flood insurance, for example, provides protection for destruction and financial devastation due to flood disasters, but it is basically the property owners' choice to purchase or not to purchase insurance because they have their own rights to be free from government interference as long as their choice does not harm anyone's rights. They do not directly violate or threaten anyone's rights by refusing to purchase 
flood insurance, and thus, their decision cannot be criticized as unjust or illegal. For this reason, the National Flood Insurance Program (NFIP), which is mandatory for federallybacked mortgage holders who live in flood prone areas, may simply be considered as a violation of residents' negative rights. However, from an institutional standpoint, the mandatory flood insurance is a preventive measure to avoid loss of opportunity to promote other's positive rights by reducing social costs that are highly likely to be caused by flood disasters. The logic behind this policy is that each homeowner has an individual duty in order to exercise their property rights, and their choice should not hamper various institutional efforts to promote social rights of all in a fair and constructive manner. Two important justice questions underlying in this situation are whether governmental institutions still have responsibility to assist people who refused to buy flood insurance in actual flooding incidents, and to what extent government can impose a duty on each individual to promote positive rights as a core component of environmental justice.

Unfortunately, clear answers to these questions are elusive because there have been no sufficient efforts to address a natural disaster as a human rights problem, and therefore, social consensus has not been reached regarding the implications of human rights-based approaches and the resolution of human rights conflicts. Nevertheless, a human rights perspective is still essential in natural disaster mitigation policy and planning because it opens up the discussion of responsibility of experts, practitioners, and decision-makers whose actions have an impact on the basic human rights of people. 
More importantly, it provides a consistent and responsive framework to manage disaster risks by regarding vulnerability as a right deprivation. In terms of human vulnerability, we may think of two reasons why governmental institutions are still obligated to assist people who refused to buy flood insurance. Firstly, the flood insurance program does not contribute to reduced physical vulnerability and often increases socioeconomic vulnerability by shifting financial burdens to a certain group of people. Flood insurance should thus be used as ancillary measures, and governmental institutions need to provide more substantive solutions that can actually reduce the vulnerability of communities. Secondly, a high level of flood vulnerability caused by reckless floodplain development and environmental destruction cannot be reduced only by individual preparedness at the household level. Thus, comprehensive and systematic institutional efforts such as floodplain zoning, development constraints, and flood warning practices are still required not only to promote individual and public safety, but also to achieve urban resilience as a communal goal.

Arguably, acknowledging human vulnerability and human rights in natural disaster mitigation is meaningful and important to develop, elaborate and practice environmental justice discourses. Even though there still remain questions to be addressed, the ideas of human vulnerability and human rights offer the possibility of both morally and socially responsible solutions by expanding the notion of environmental justice from liberalism to critical pluralism. Ultimately, the essence of environmental justice in natural disaster mitigation lies in realizing the fact that some of 
our moral and social perceptions and judgments may be mistaken, and many of our practices can be unjust without understanding the particularity and difference of people and their situations. 


\section{Conclusions}

As Wenz (1988) mentioned, we as average members of society receive many benefits from the world's environmental injustices. Technogenic impacts due to rapid urbanization and reckless industrialization in recent decades have caused serious natural resource depletion, environmental destruction, and climate change endangering the health and safety of many innocent people. Under the paradigm of economic growth, basic rights for a healthy environment were frequently violated and the vulnerability to natural disasters and other environmental crisis became disproportionately distributed among people having different socioeconomic positions and statuses.

From this point of view, this study attempted to address environmental justice through the socialization of natural disasters. Obviously, environmental justice based on human rights should be consistently promoted in natural disaster mitigation policy and planning because it enables effective identification of socioeconomic determinants of disaster risk, and encourages both social and moral obligations with respect to human dignity and community values. Consequently, this study suggests that human vulnerability and human rights, as guiding principles of environmental justice, should not be viewed merely as an add-on to the disaster mitigation agenda. Rather, the ideas should be continuously discussed, tested and refined to achieve the purity of planning purpose, the appropriateness of planning process, and the fairness and equity of planning outcome at the same time. 
At this point, it is worthy to note the limitations of analytical methods used in this study because they provide directions for future research that can expand our understanding of natural disasters as environmental justice problems. First, even though the indicator-based method allowed a comprehensive understanding of flood vulnerability conditions in the Johnson Creek area, whether selected indicators were sufficient to fully reflect the local situation and context is unclear. For a more comprehensive assessment, a wider range of other indicators should also be considered and adapted through a collaborative discussion with local residents who have been affected by flood disasters. For example, indicators such as 'past experience' (number of flood-affected people in the last 10 years), 'communication penetration rate' (percentage of households with sources of information), and 'cultural heritage' (number of historical buildings, museums, etc. in danger when flood occurs) may provide supplementary information to better understand local conditions and reflect the community voice. Birkmann (2006) asserted that the main interest of indicator-based method is not in the indicator itself, but in the 'indicandum' (the subject to be indicated). Assessing vulnerability in this respect should be a heuristic process of how we are assigning a meaning to the indicator and defining the value and function of the indicator in the context of confronting issues. Accordingly, the question about how to utilize disaster vulnerability assessment as an opportunity of participatory decision-making and social learning still remains for future study.

Second, this study used Q-methodology to explore flood experts' and urban 
practitioners' subjective views on the topics of environmental justice and human rights. Q-methodology combines the strength of both qualitative and quantitative research traditions, and thus has the advantage of translating a particular individual's dialogue into a systematic analysis. Despite its usefulness for comparative perceptions analysis, there are some notable disadvantages in using Q-methodology. One of main limitations is the lack of reliability that may provide little basis for systematic generalization. There is always a possibility that the results of Q-sorting many not be the same even if it is repeated on the same respondent. In order to avoid this problem, this study had to minimize the cognitive burden of respondents by limiting the number of Q-statements and simplifying each statement to be clear and concise. The findings of Q-methodology are not intended to be generalized beyond the individuals who participated in the Qsorting activity. However, this study provides a basis for future research to assess whether the results are also seen in other cases, and therefore, potentially generalizable for understanding attitudes, perceptions and perspectives of other groups of planners, engineers and politicians who are involved with natural disaster mitigation policy and planning.

The other disadvantage of using Q-methodology is that pre-determined statements may limit the scope of discourse by forcing participants to mainly focus on the Q-sorting process. For this reason, it was critically important to ensure that participants have a set of statements that covers the full range of views held about the topics, and capture participants' views that are not revealed during the $\mathrm{Q}$-sorting 
process through in-depth follow-up interviews. This means that the discourse of environmental justice can be expanded and enriched in future study by offering participants a deeper and broader range of Q-statements, and better allowing them to share their ideas, insights and questions about the topics.

Moreover, the discourse of environmental justice includes various other profound topics such as animal rights, bio-centric individualism, and eco-centric holism, which are considered beyond the extent of this study. Although discussions here focused only on a limited range of environmental justice issues from a human-centered perspective, this study nonetheless has significant meaning in that it approached a natural disaster as a social problem that can be remedied through shared understanding of environmental justice and our commitment to human rights. This study can be the foundation of further research on the relationship between human rights as an internal principle and human obligations as external principle of environmental justice.

The logic of 'we are assailants and victims at the same time' often makes it difficult to address the problem of the imbalance between people who benefits and suffers from environmental injustice. We as a society have an obligation to do something about the situation by understanding theoretical and practical implications of environmental justice, and ensuring common and differentiated responsibility to solve problems that involves violations of people's human rights. The desperate needs of vulnerable and disadvantaged people should not be ignored for the relatively selfish desires of people with power and privilege. Arguably, we can ameliorate the situation by 
recognizing environmental injustice around us, questioning our perceptions and understanding of basic human rights, and ensuring the fair, just and equitable implementation of public policies. 


\section{References}

Adger, W.N. (2006). “Vulnerability”. Global Environmental Change 16(3): 268-281.

Ahilan, S. et al. (2018). "The influence of floodplain restoration on flow and sediment dynamics in an urban river". Journal of Flood Risk Management 11: S986-S1001.

ASFPM. (2015). National Flood Programs and Policies in Review. The Association of State Flood Plain Managers. (Retrieved January 16, 2018 from http://www.floods.org/ ace-files/documentlibrary/committees/NFPPR_20150128/NFPPR_2015.pdf).

Banerjee, D. (2018). Conceptualizing Environmental Justice: Plural Frames and Global Claims in Land between the Rivers, Kentucky. Lexington Books.

Barroca, B. et al. (2006). "Indicators for identification of urban flooding vulnerability". Natural Hazards and Earth System Sciences 6: 553-561.

Beckham Hooff, S. et al. (2017). "Seeing the wind (farm): Applying Q-methodology to understand the public's reception of the visuals around a wind farm development". Environmental Communication 11(5): 700-722.

Becker, L.C., and Becker, C.B. (Eds.) (2001). Encyclopedia of Ethics. Routledge, New York.

Birkmann, J. (2006). Measuring Vulnerability to Natural Hazards: Towards Disaster Resilient Societies. United Nations University Press, Tokyo, New York, Paris.

Bookchin, M. (1998). Remaking Society. Black Rose Books.

Boesen, J.K., and Martin, T. (2007). Applying A Rights-based Approach: An Inspirational Guide for Civil Society. The Danish Institute of Human Rights, Copenhagen, Denmark.

Brown, S. (1980). Political subjectivity: application of Q methodology in political science. Yale University Press, New Haven.

Budd, J.W., and Scoville, J.G. (Eds.) (2005). The Ethics of Human Resources and Industrial Relations. Labor and Employment Relations Association, Champaign.

Bureau of Environmental Services. (2001). Johnson Creek Restoration Plan. (Retrieved November 23, 2017 from https://www. portlandoregon.gov/bes/article/214367).

(2014). Lents Flood Mitigation Matters: Unlocking the Potential of Outer Southeast Portland. City of Portland. (Retrieved March 3, 2018 from http://orsolutions.org/wp-content/uploads/2016/08/Lents-Flood-MitigationMatters-r1.pdf).

(2018a) "Johnson Creek Watershed History". City of Portland. (Accessed July 23, 2017 https://www.portlandoregon.gov/bes/article/214282). 
-------. (2018b) “Foster Floodplain Natural Area”. City of Portland. (Accessed January 2, 2018 https://www.portlandoregon.gov/bes/article/286175).

--------. (2018c) “Community Rating System". City of Portland. (Accessed January 2, 2018 https://www.portlandoregon.gov/bes/article/566732).

Cardona, O.D. (2004). The need for rethinking the concepts of vulnerability and risk from a holistic perspective: A necessary review and criticism for effective risk management. In Bankoff, G., Frerks, G., and Hilhorst, D. (Eds.) Mapping vulnerability: Disasters, development and people. Earthscan, London.

Cartwright, L. (2005). "An examination of flood damage data trends in the United States". Journal of Contemporary Water Research and Education 130: 20-25.

Cho, S.Y., and Chang, H. (2017). "Recent research approaches to urban flood vulnerability, 2006-2016". Natural Hazards 88(1): 633-649.

Cramme, O., and Diamond, P. (2009). Rethinking social justice in the global age. In Cramme, O. and Diamond, P. (Eds.) Social justice in the global age. Polity Press, Cambridge, UK.

Cutter, S.L. et al. (2008). "A place-based model for understanding community resilience to natural disasters". Global Environmental Change 18(4): 598-606.

Davy, B. (1997). Essential Injustice. Springer, Wien/New York.

Eriksen, S.H., and Kelly, P.M. (2007). "Developing Credible Vulnerability Indicators for Climate Adaptation Policy Assessment". Mitigation and Adaptation Strategies for Global Change 12(4): 495-524.

FEMA. (2011a). The Response to the 2011 Joplin, Missouri, Tornado: Lessons Learned Study. Federal Emergency Management Agency. Washington, D.C.

---------. (2011b). A Whole Community Approach to Emergency Management: Principles, Themes, and Pathways for Action. Federal Emergency Management Agency. FDOC 104-008-1/December 2011.

--------. (2017). National Flood Insurance Program Community Rating System Coordinator's Manual. FIA-15/2017. OMB No. 1660-0022.

Fischer, F. (1998). "Beyond empiricism: Policy inquiry in postpositivist perspective". Policy Studies Journal 26(1): 129-146.

Füssel, H.M. (2007). "Vulnerability: a generally applicable conceptual framework for climate change research". Global Environmental Change 17(2): 155-167.

Garner, R. (2017). "Bovine TB, Badger Culling and Applied Ethics: Utilitarianism, Animal Welfare and Rights". Journal of Agricultural and Environmental Ethics. 30(4): 579- 
584.

Gorovitz Robertson, H. (2008). Controlling Existing Facilities. In Gerrard, M.B., and Foster, S.R. (Eds.) The Law of Environmental Justice: Theories and Procedures to Address Disproportionate Risks. American Bar Association, Chicago.

Hartman, T., and Spit, T. (2015). "Dilemmas of involvement in land management Comparing an active (Dutch) and a passive (German) approach". Land Use Policy 42: 729-737.

Heijmans, A. (2004). From Vulnerability to Empowerment. In Bankoff, G., Frerks, G., and Hilhorst, D. (Eds.) Mapping vulnerability: Disasters, development and people. Earthscan, London.

Innes, J., and Booher, D. (2010). Planning with Complexity: An Introduction to Collaborative Rationality for Public Policy. Routledge, New York.

Johnson, S. (2008). The Johnson Creek Story. (Retrieved June 2, 2017 from http://www.stevenreedjohnson.com/stevenreedjohnson/civicpdxJcreek_files/Joh nsonCreekStory.pdf).

Jonsson, U. (2003). Human Rights Approach to Development Programming. UNICEF, Nairobi.

Kahrl, A.W. (2014). "The Sunbelt's Sandy Foundation: Coastal Development and the Making of the Modern South". Southern Cultures 20(3), 24-42.

Kamal, S. et al. (2014). "Quantifying Human Subjectivity Using Q Method: When Quality Meets Quantity". Qualitative Sociology Review 10(3): 61-79.

Kamel, N. (2012). "Social Marginalization, Federal Assistance and Repopulation Patterns in the New Orleans Metropolitan Area Following Hurricane Katrina." Urban Studies 49(14): 3211-3231.

Keen, A. (2012). Digital Vertigo: How today's online social revolution is dividing, diminishing, and disorienting us. St. Martin's Press, New York.

Killcreas, A.H. (2012). "The Power of Community Action: Environmental Justice and Participatory Democracy in Mississippi," Mississippi Law Journal 81(4): 769-812.

Kim, A. (2017). "Acceptance of Complementary and Alternative Therapy among Nurses: A Q-methodological Study". Korean Journal of Adult Nursing 29(4): 441-449.

Konisky, D.M. (2015). Failed promises: Evaluating the Federal Government's Response to Environmental Justice. MIT Press. Cambridge.

Kosko, S.J (2013). "Agency vulnerability, participation, and the self-determination of indigenous peoples". Journal of Global Ethics 9(3): 293-310. 
Liu, F. (2001). Environmental Justice Analysis: Theories, Methods and Practice. CRC Press, Boca Raton.

Mathis, K. (2009). Efficiency Instead of Justice? Searching for the Philosophical Foundations of the Economic Analysis of Law. Springer.

Mayer, M., and DeBosier, M. (2010). Federalizing Disasters Weakens FEMA - and Hurts Americans Hit by Catastrophes. The Heritage Foundation. (Retrieved December 12, 2017 from https://www.heritage.org/homeland-security/report/federalizingdisasters-weakens-fema-and-hurts-americans-hit-catastrophes).

Militello, M., and Benham, M.K.P. (2010). "'Sorting Out' collective leadership: How Qmethodology can be used to evaluate leadership development. The Leadership Quarterly 2010(21): 620-632.

Miller, J.R. et al. (2003) The Encyclopedia of Human Ecology. ABC-CLIO, Santa Barbara.

Morrow, B.H. (2008). Community Resilience: A Social Justice Perspective. Community and Regional Resilience Institute (CARRI) Research Report 4.

Morse, R. (2008). Environmental Justice through the Eye of Hurricane Katrina. Joint Center for Political and Economic Studies, Health Policy Institute, Washington, D.C.

Nair, P. S. (Eds.) (2011). Human Rights in a Changing World. Kalpaz Publications, Delhi.

Nasiri, H. et al. (2016). "An overview to flood vulnerability assessment methods". Sustainable Water Resources Management. 2(3): 331-336.

Nozick, R. (1974). Anarchy, State, and Utopia. Basic Books, New York.

Paige, J.B. (2014). "Making sense of methods and measurements: Q-methodology - Part I: philosophical background". Clinical Simulation in Nursing 10(12): 639-640.

Pandey, R., and Bardsley, D. (2015). "Social-ecological vulnerability to climate change in the Nepali Himalaya". Applied Geography. 64: 74-86.

Parker, D., and Tapsell, S. (2009). Deliverable 2.1: Relations between different types of social and economic vulnerability. Final draft report submitted to EU project Enhancing resilience of communities and territories facing natural and na-tech hazards (ENSURE).

Paul, B.K. (2011). Environmental Hazards and Disasters: Contexts, Perspectives and Management. Wiley-Blackwell, Chichester, UK.

Philips, D.L. (1986). Toward a Just Social Order. Princeton University Press, Princeton.

Platt, R.H. (1999). Disasters and Democracy: The politics of extreme natural events. 
Island Press, Washington, D.C.

Polsky, C., Neff, R., and Yarnal, B. (2007). "Building comparable global change vulnerability assessments: the vulnerability scoping diagram". Glob Environ Change 17(3-4):472-485.

Rawls, J. (1971). A Theory of Justice. Harvard University Press, Cambridge.

(1975). A Kantian Conception of Equality. In Freeman, S. (Eds.) (1999). John Rawls - Collected Papers. Harvard University Press, Cambridge.

Sandel, M. (1982). Liberalism and the limits of justice. Cambridge University Press, Cambridge, UK.

Schanze, J., Zeman, E., and Marsalek, J. (2006). Flood risk management: hazards, vulnerability and mitigation measures. Springer, Dordrecht, the Netherlands.

Simons, J. (2013). "An introduction to Q methodology". Nurse researcher 20(3), 28-32.

Stephenson, W. (1986). "Protoconcursus: The concourse theory of communication". Operant Subjectivity 9(2): 37-58.

Strauss, L. (1953). Natural Rights and History. University of Chicago Press, Chicago.

Squires, J. (2013). Equality and universalism. In Waylen G., Celis, K., Kantola, J. and Weldon L. (Eds.) The Oxford Handbook on Gender and Politics. Oxford University Press.

The White House. (2015). Progress Report: Highlighting Federal Actions Addressing the Recommendations of the State, Local, and Tribal Leaders Task Force on Climate Preparedness and Resilience. The White House. Washington, D.C.

Turner, B.L. et al. (2003). "A framework for vulnerability analysis in sustainability science". Proceedings of National Academy of Sciences of the United States of America (PNAS) 100(14): 8074-8079.

Turner, B.S. (2006). Vulnerability and Human Rights. Pennsylvania State University Press, University Park.

Twigg, J. (2004). Good Practice Review: Disaster Risk Reduction - Mitigation and Preparedness in Development and Emergency Programming. Humanitarian Practice Network, Overseas Development Institute, London.

UNEP. (2002). Global Environmental Outlook 3: Past, Present, and Future Perspectives. Earthscan, London.

UNFPA. (2010). A Human Rights-Based Approach to Programming: Practical Implementation Manual and Training Materials. United Nations Population Fund 
and Harvard School of Public Health. (Retrieved January 18, 2018 from https://www.unfpa.org/resources/human-rights-based-approach-programming).

UN/ISDR. (2004). Living with risk: A global review of disaster reduction initiatives. United Nations International Strategy for Disaster Reduction, Geneva, Switzerland.

Vojinović, Z., and Abbott, M.B. (2012). Flood risk and social justice: From Quantitative to Qualitative Flood Risk Assessment and Mitigation. IWA Publishing, London.

Walzer, M. (1983). Spheres of Justice: A Defense of Pluralism and Equality. Basic Books, New York.

Watts, S., and Stenner, P. (2012). Doing Q methodological research: Theory, method \& interpretation. Sage Publications, London.

Wenz, P.S. (1988). Environmental Justice. SUNY Press, New York.

Wisner, B. et al. (2003). At Risk: Natural Hazards, People's Vulnerability and Disasters. Routledge, London.

Yoon, D.K. (2012). "Assessment of social vulnerability to natural disasters". Natural Hazards 63(2): 823-843.

Young, I.M. (1990). Justice and the Politics of Difference. Princeton University Press, Princeton. 
Thank you for agreeing to take part in this survey. Your participation will help me to better understand issues and concerns on Johnson Creek floods and develop a more comprehensive approach to flood vulnerability assessment. The survey is divided into four sections and will take approximately 30 minutes to complete. Questions are multiple choice and text entry. Your participation is completely voluntary and your comments will not be shared in any other way without your permission.

Once again, thank you for your time and sharing your opinions.

\section{Section 1: Johnson Creek Floods}

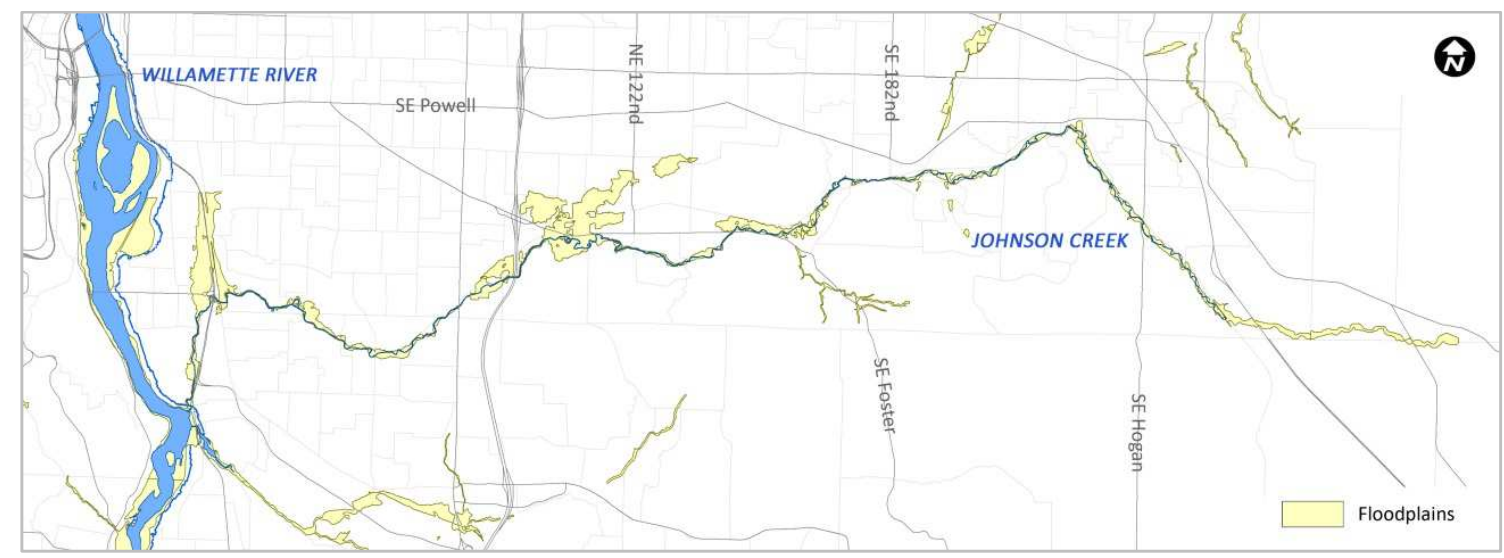

Q1. How would you characterize the current flood risks of Johnson Creek?

$\square$ Extremely problematic

$\square$ Very problematic

$\square$ Moderately problematic

$\square$ Slightly problematic

$\square$ Not at all problematic

$\square$ Don't know

Q2. Do you agree that Johnson Creek is more prone to floods than other rivers and creeks in Portland?

$\square$ Strongly agree

$\square$ Somewhat agree

$\square$ Neither agree nor disagree

$\square$ Somewhat disagree

$\square$ Strongly disagree

$\square$ Don't know 
Q3. Do you agree that the impact and damage of Johnson Creek floods will be more severe in the future?

$\square$ Strongly agree

$\square$ Somewhat agree

$\square$ Neither agree nor disagree

$\square$ Somewhat disagree

$\square$ Strongly disagree

$\square$ Don't know

Q4. Thinking of the causes of floods, which best describes your opinion?

$\square$ Johnson Creek floods are entirely caused by natural factors

$\square$ Johnson Creek floods are mainly caused by natural factors

$\square$ Johnson Creek floods are partly caused by natural factors and partly caused by human activities

$\square$ Johnson Creek floods are mainly caused by human activities

$\square$ Johnson Creek floods are entirely caused by human activities

$\square$ Don't know

Q5. What do you think is the major problem of Johnson Creek floods?

$\square$ Extreme weather events

$\square$ Lack of structural flood control measures such as levees, flood walls and reservoirs

$\square$ Differences in local residents' socioeconomic capacity to cope with flood risks

$\square$ Insufficient institutional and policy support

$\square$ Don't know

$\square$ Other (Please specify):

Q6. Do you think that Johnson Creek floods are a socioeconomic problem rather than a technological and engineering problem?

$\square$ Strongly agree

$\square$ Somewhat agree

$\square$ Neither agree nor disagree

$\square$ Somewhat disagree

$\square$ Strongly disagree

$\square$ Don't know 
Q7. Do you agree that each community and neighborhood in Johnson Creek area has different capacity to prepare for, respond to, and recover from flood events?
$\square$ Strongly agree
$\square$ Somewhat agree
$\square$ Neither agree nor disagree
$\square$ Somewhat disagree
$\square$ Strongly disagree
$\square$ Don't know

Q8. Do you agree that Johnson Creek floods are a city-wide problem rather than a neighborhood problem?

$\square$ Strongly agree
$\square$ Somewhat agree
$\square$ Neither agree nor disagree
$\square$ Somewhat disagree
$\square$ Strongly disagree
$\square$ Don't know

Q9. What would be your preferred methods for mitigating flood risks of Johnson Creek?

Section 2: Flood Disasters and Environmental Justice

Please indicate your opinion based on each statement.

Q10. Floods affect to socioeconomically vulnerable populations most.

$\square$ Strongly disagree $\square$ Somewhat disagree $\quad \square$ Neither $\quad \square$ Somewhat agree $\square$ Strongly agree

Q11. The solution to flood problems should be focused around cost efficiency.

\begin{tabular}{lll}
\hline Strongly disagree $\quad \square$ Somewhat disagree $\quad \square$ Neither $\quad \square$ Somewhat agree $\square$ Strongly agree \\
\hline
\end{tabular}


Q12. It is important to consider not only physical but also socioeconomic vulnerability of local communities to flood risks.

$\square$ Strongly disagree $\square$ Somewhat disagree $\quad \square$ Neither $\quad \square$ Somewhat agree $\square$ Strongly agree

Q13. Local government has responsibility to take care of socioeconomically vulnerable populations.

\begin{tabular}{l}
$\square$ Strongly disagree $\quad \square$ Somewhat disagree $\quad \square$ Neither $\quad \square$ Somewhat agree $\square$ Strongly agree \\
\hline
\end{tabular}

Q14. Environmental justice is a critical part of flood mitigation policy and planning.

$\square$ Strongly disagree $\square$ Somewhat disagree $\square$ Neither $\square$ Somewhat agree $\square$ Strongly agree

Q15. Successful flood mitigation must place human rights at the center.

$\square$ Strongly disagree $\square$ Somewhat disagree $\square$ Neither $\square$ Somewhat agree $\square$ Strongly agree

Q16. In terms of flood risk mitigation, individual rights (such as property rights and rights of residence) can be violated or sacrificed in the name of public safety.

$\square$ Strongly disagree $\square$ Somewhat disagree $\square$ Neither $\square$ Somewhat agree $\square$ Strongly agree

Q17. What approaches does your department, agency or organization use to respond to environmental justice concerns?

$\square$ Socioeconomic/Demographic analysis

$\square$ Communication with stakeholders and the public

$\square$ None

$\square$ Other (Please specify):

Q18. Are you aware of EPA guidance on environmental justice to ensure compliance with Executive Order 12898 (Federal actions to address environmental justice in minority and low-income populations)?

$\square$ Yes

$\square$ No

Q19. What do you think would be the most important component of environmental justice? Please rank the following challenges in terms of their importance in achieving environmental justice (From 1 to 5 , using 1 as the most important).

Leadership, political will and vision

More non-governmental organizations and intermediate groups to support socioeconomically vulnerable populations

_ Sufficient funding and policy support

_ High level of public awareness of socioeconomic disparities in society Active and meaningful public participation 
Q20. If you have any other concerns besides challenging issues listed above, please specify below.

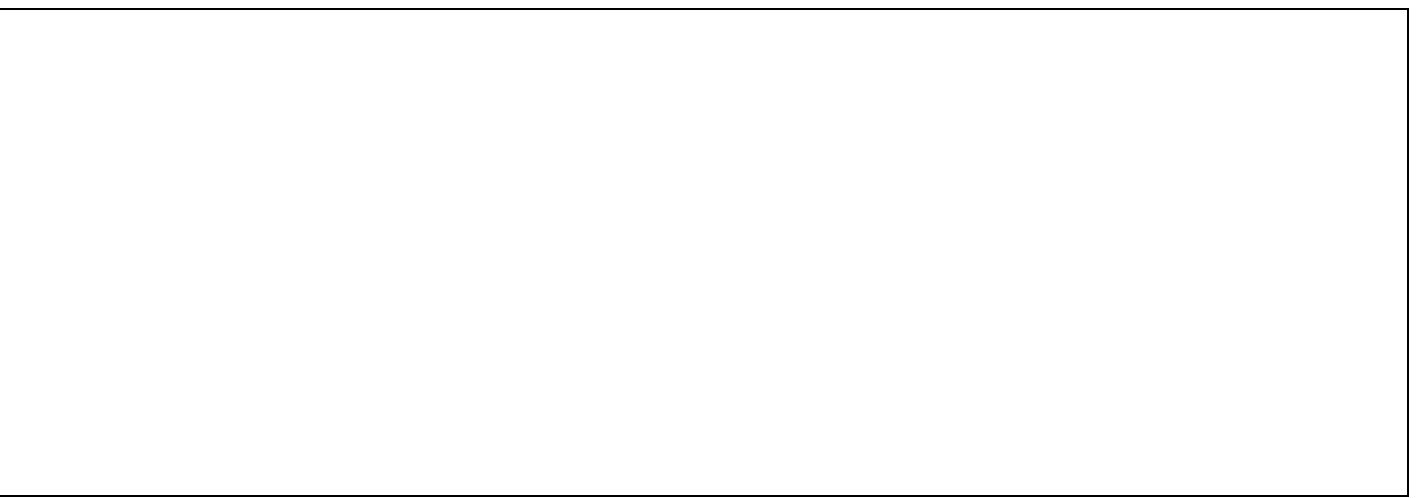


Section 3: Flood Vulnerability Assessment

Q21. The followings are flood vulnerability indicators collected from literature review. Which indicator do you think should be considered importantly to assess flood vulnerability of communities along Johnson Creek? Please indicate whether each indicator listed below is important or not important.

\begin{tabular}{|c|c|c|c|c|}
\hline Indicators & Definitions & $\begin{array}{c}\text { Very } \\
\text { important }\end{array}$ & $\begin{array}{l}\text { Somewhat } \\
\text { important }\end{array}$ & $\begin{array}{l}\text { Not } \\
\text { important }\end{array}$ \\
\hline Age & $\begin{array}{l}\text { Percentage of residents who have difficulties evacuating a building } \\
\text { independently in case of an emergency (e.g., Under } 18 \text { and over 64) }\end{array}$ & $\square$ & $\square$ & $\square$ \\
\hline Age of structure & Percentage of old buildings (e.g., Buildings constructed before 1950) & $\square$ & $\square$ & $\square$ \\
\hline Contamination & $\begin{array}{l}\text { Proximity to contaminated sites (e.g., Underground storage tank, } \\
\text { Hazardous waste site, Extremely hazardous substance site) }\end{array}$ & $\square$ & $\square$ & $\square$ \\
\hline Disability & Percentage of residents with physical or mental disabilities & $\square$ & $\square$ & $\square$ \\
\hline Economic activity & Percentage of commercial and industrial buildings & $\square$ & $\square$ & $\square$ \\
\hline Education & Percentage of people with less than high school diploma & $\square$ & $\square$ & $\square$ \\
\hline Ethnicity/Race & Percentage of residents from communities of color & $\square$ & $\square$ & $\square$ \\
\hline Green space & Area of green space that could effectively hold flood waters & $\square$ & $\square$ & $\square$ \\
\hline Hospital & Proximity and accessibility to hospitals & $\square$ & $\square$ & $\square$ \\
\hline Household size & Percentage of 5 or more person family and nonfamily households & $\square$ & $\square$ & $\square$ \\
\hline Housing type & $\begin{array}{l}\text { Percentage of residents who have less ability or incentive to take } \\
\text { mitigation action (e.g., Rental dwellings) }\end{array}$ & $\square$ & $\square$ & $\square$ \\
\hline Initial emergency response & Proximity and accessibility from fire stations & $\square$ & $\square$ & $\square$ \\
\hline Language & Percentage of residents who speak English 'not well' or 'not at all' & $\square$ & $\square$ & $\square$ \\
\hline
\end{tabular}




\begin{tabular}{|c|c|c|c|c|}
\hline Indicators & Definitions & $\begin{array}{l}\text { Very } \\
\text { important }\end{array}$ & $\begin{array}{l}\text { Somewhat } \\
\text { important }\end{array}$ & $\begin{array}{l}\text { Not } \\
\text { important }\end{array}$ \\
\hline Location & Distance from the creek and ground elevation & $\square$ & $\square$ & $\square$ \\
\hline Population density & Total population per area & $\square$ & $\square$ & $\square$ \\
\hline Poverty & Percentage of residents below poverty line & $\square$ & $\square$ & $\square$ \\
\hline Shelter & $\begin{array}{l}\text { Proximity and accessibility to shelters (e.g., Public school, Library, } \\
\text { Community center) }\end{array}$ & $\square$ & $\square$ & $\square$ \\
\hline Stormwater infrastructure & $\begin{array}{l}\text { Length of flood defense structures (e.g., Constructed channel, Ditch, } \\
\text { Green street facility) }\end{array}$ & $\square$ & $\square$ & $\square$ \\
\hline Transportation & Public transportation options ( e.g., MAX, Streetcar, Bus) & $\square$ & $\square$ & $\square$ \\
\hline Unemployment & Percentage of people in the civilian labor force who are not working & $\square$ & $\square$ & $\square$ \\
\hline
\end{tabular}

占 
Q22. Besides indicators above, is there any other indicator which should be included to assess flood vulnerability in Johnson Creek area? If there is, please specify below and explain why you believe this indicator is important.

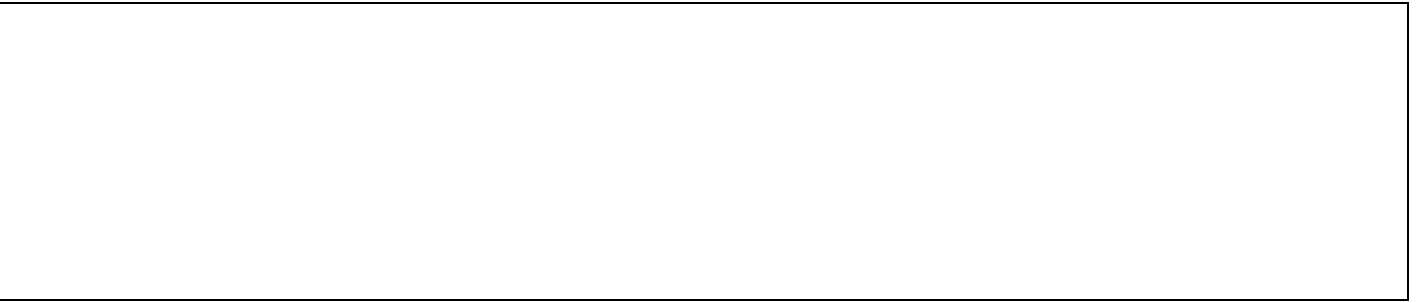

Q23. Which indicators do you think would be especially important to assess flood vulnerability in Johnson Creek area? Please specify below and explain why you believe these indicators are especially important.

Q24. Based on your experience and knowledge, please list facilities or areas that you feel are most vulnerable to Johnson Creek floods.

Section 4: Individual Information

Please remember that your responses are entirely confidential.

Q25. How closely are you involved with the decision-making process for Johnson Creek flood risk management?

$\square$ Strongly involved

$\square$ Somewhat involved

$\square$ Barely involved

$\square$ Not involved at all 
Q26. Please provide your current affiliation and position.

Q27. How long have been in your current position?

Q28. What is your main academic background?

$\square$ Social Science (Please specify):

$\square$ Environmental / Natural Science (Please specify):

$\square$ Civil / Environmental Engineering (Please specify):

$\square$ Other (Please specify):

Q29. Are you active in any association or organization related to Johnson Creek flood mitigation or restoration work? If yes, please give name of association or organization.

$\square$ Yes:

$\square$ No

Q30. Please use the space below to write any additional comments you have about issues of Johnson Creek floods. 


\section{Appendix B -1: Johnson Creek Physical Flood Vulnerability Results}

\section{PVI 1: Location}

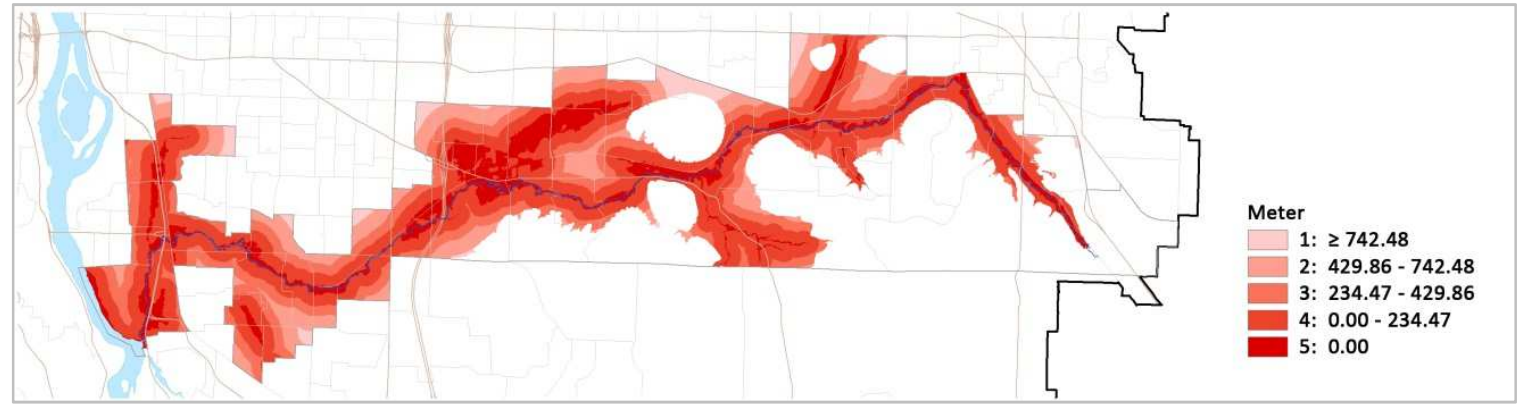

PVI 2: Contamination

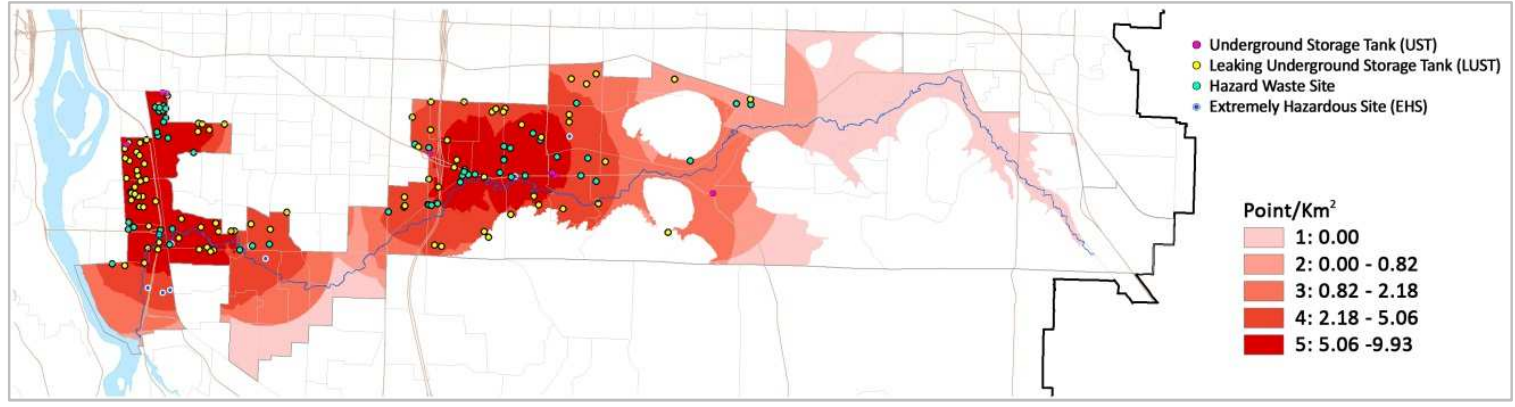

PVI 3: Stormwater infrastructure

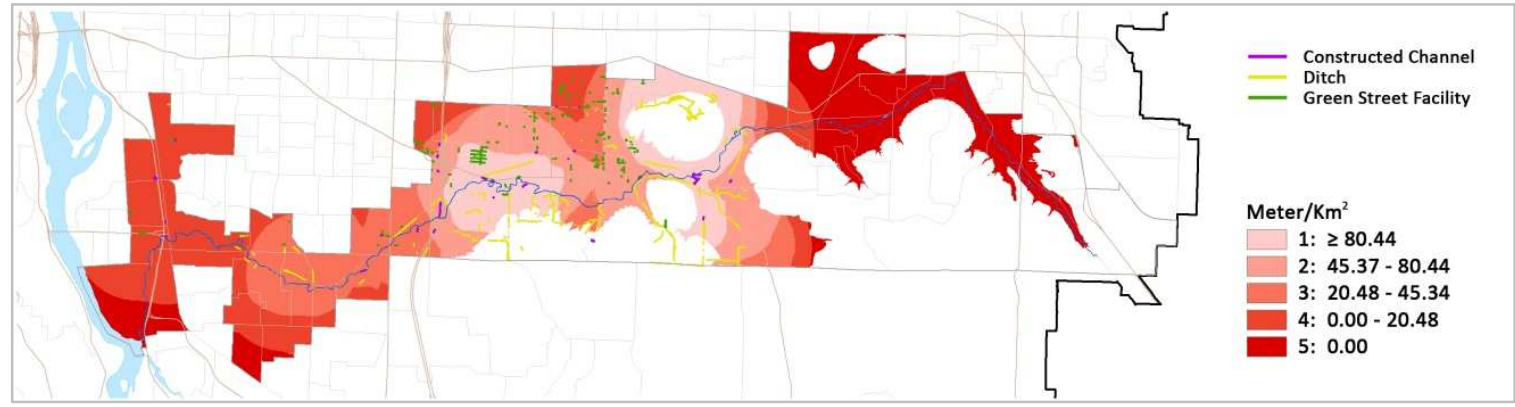

PVI 4: Age of structure

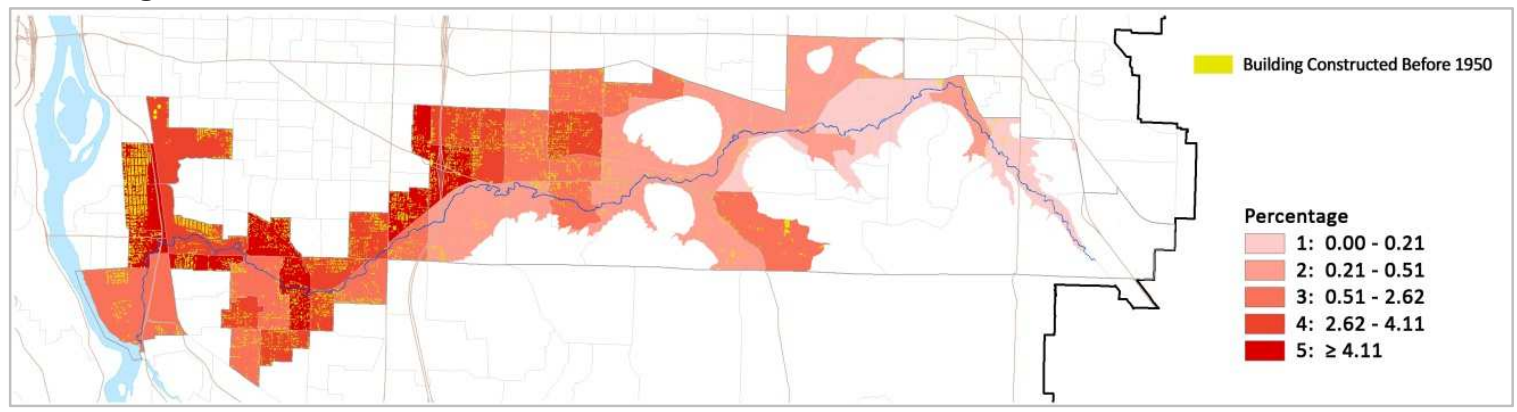


PVI 5: Green space

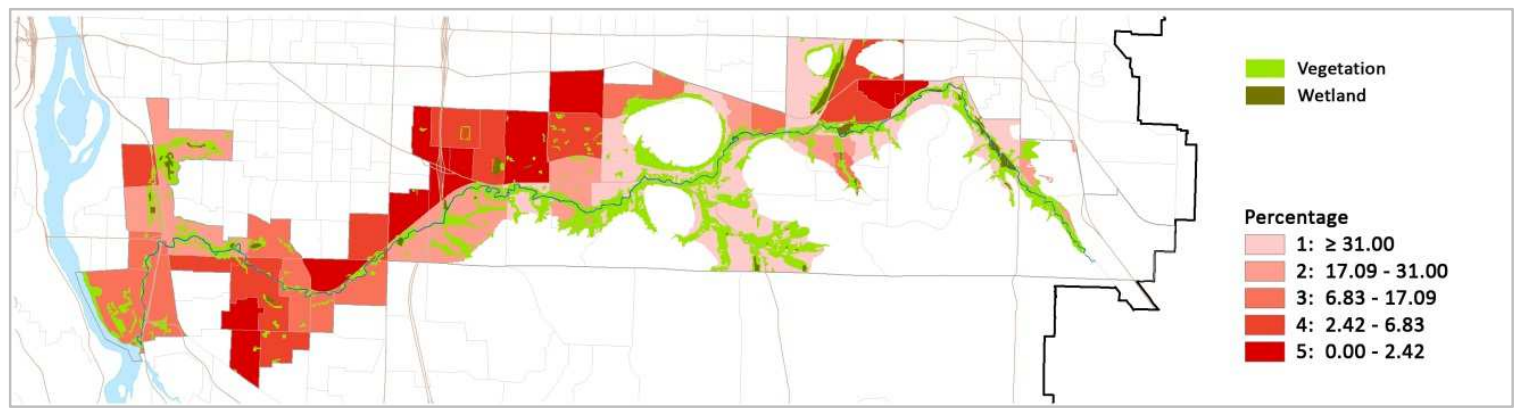

\section{PVI 6: Transportation options}

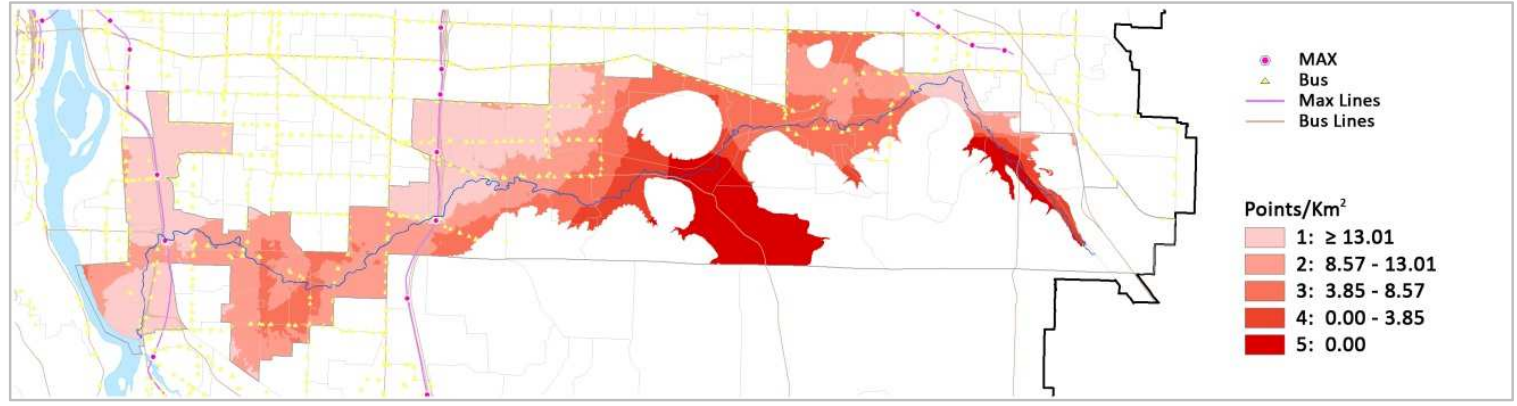

PVI 7: Shelter

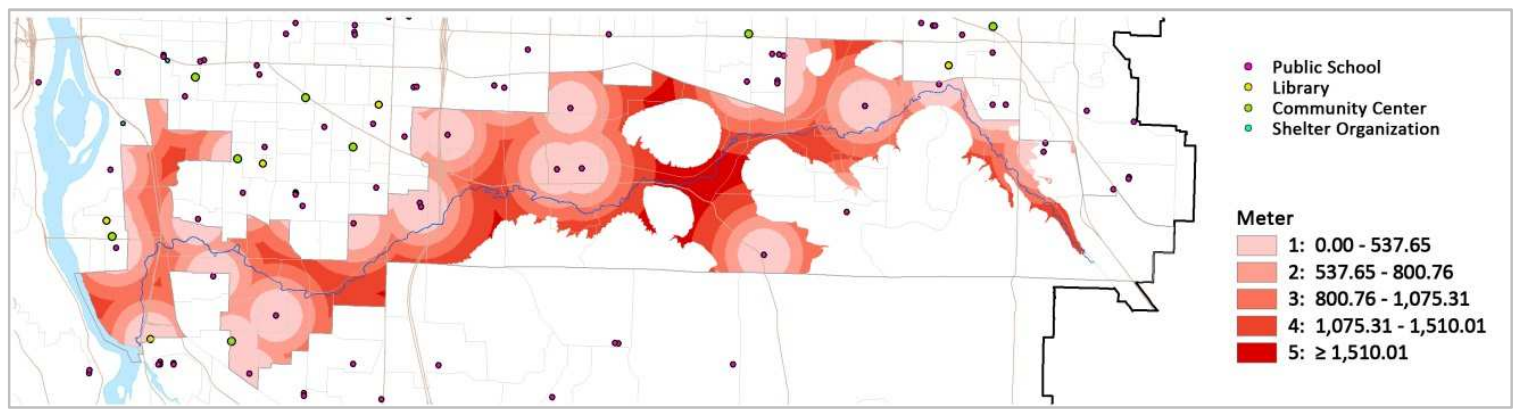

PVI 8: Hospital

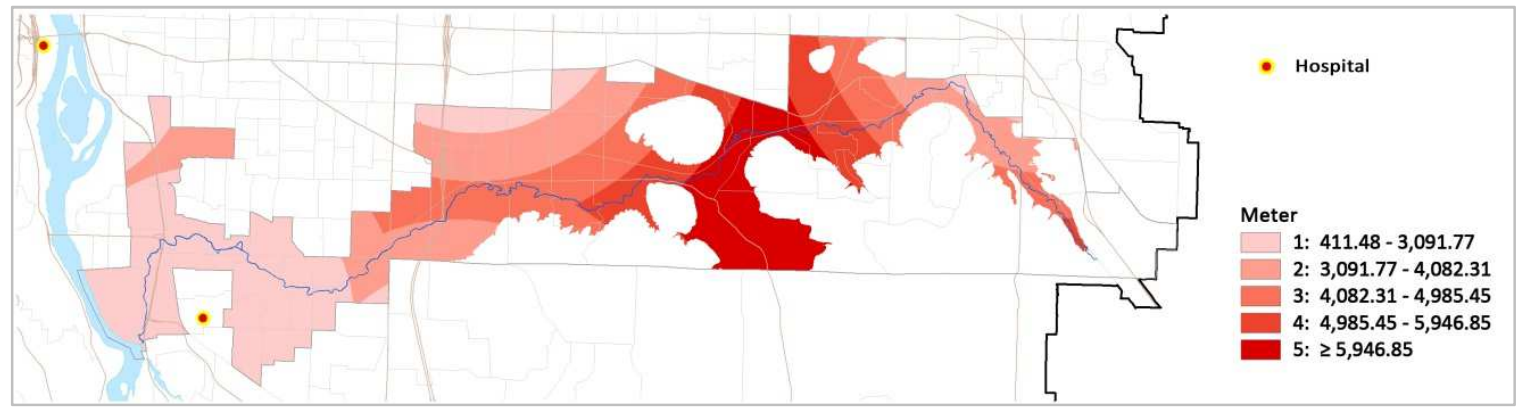


PVI 9: Initial emergency response

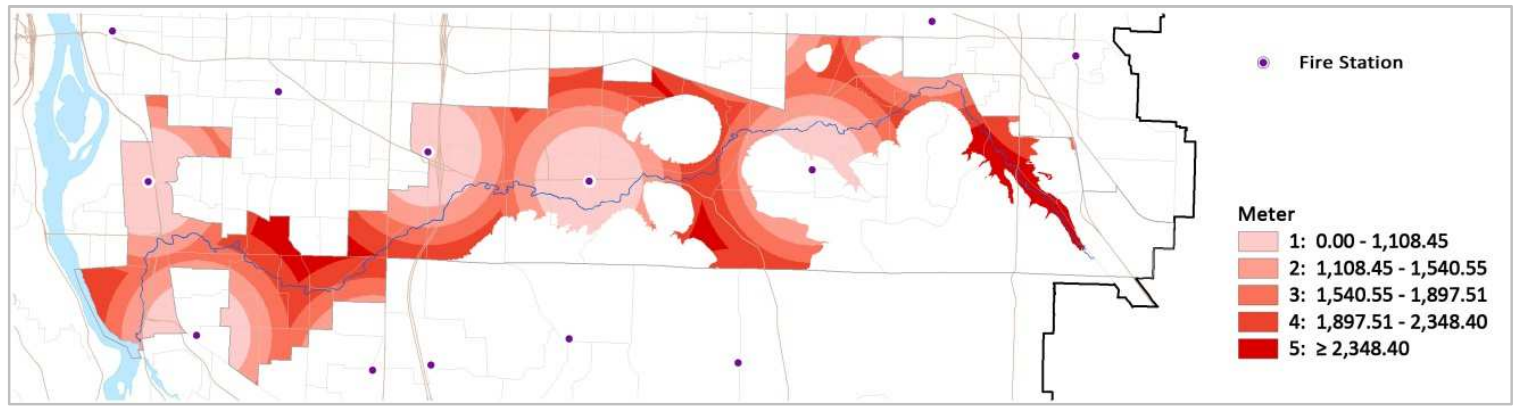

PVI 10: Population density

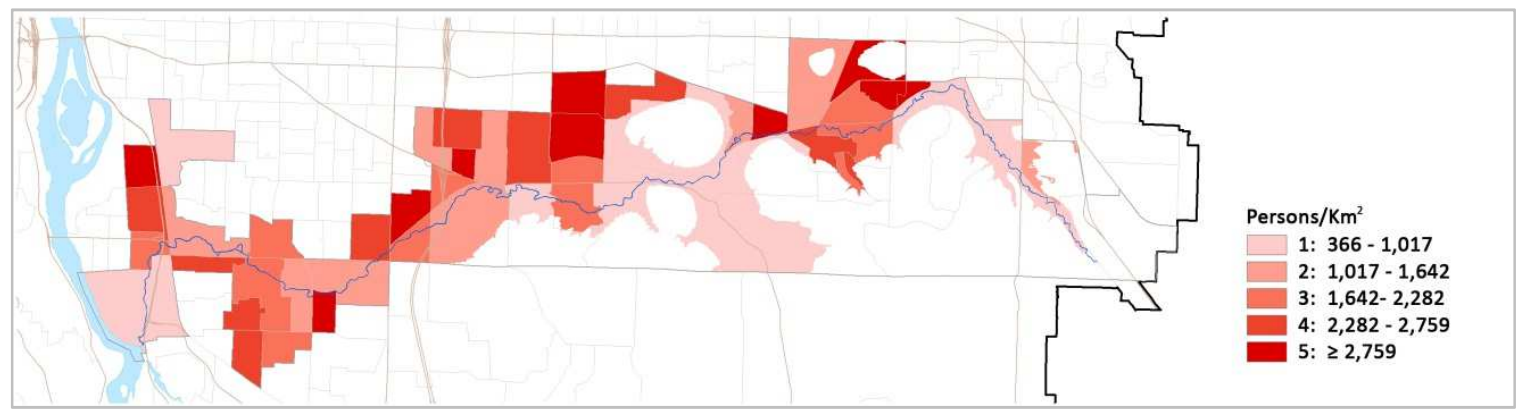


Appendix B-2: Johnson Creek Socioeconomic Flood Vulnerability Results

SVI 1: Poverty

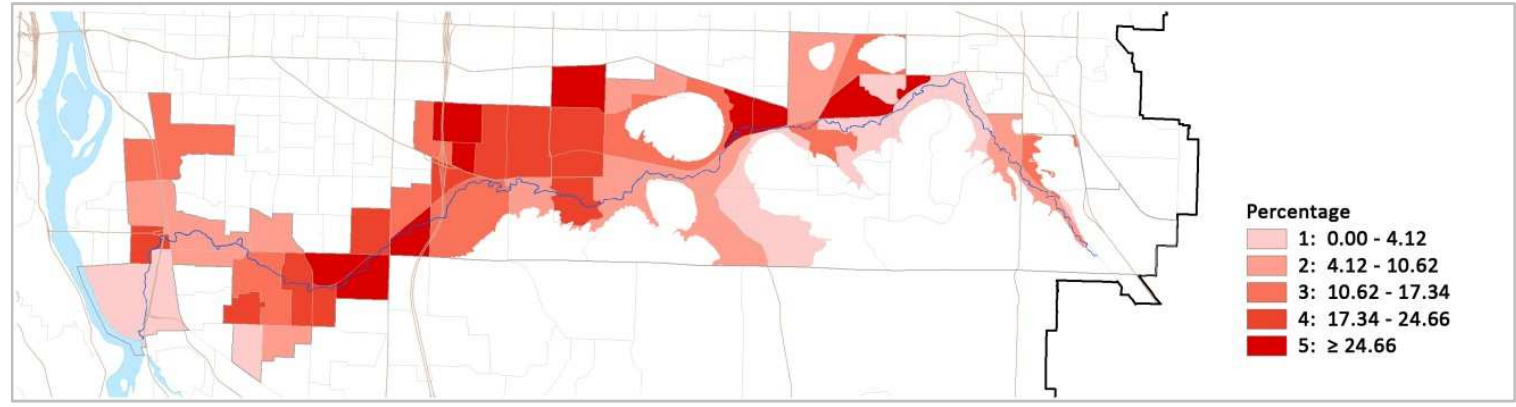

SVI 2: Economic activity

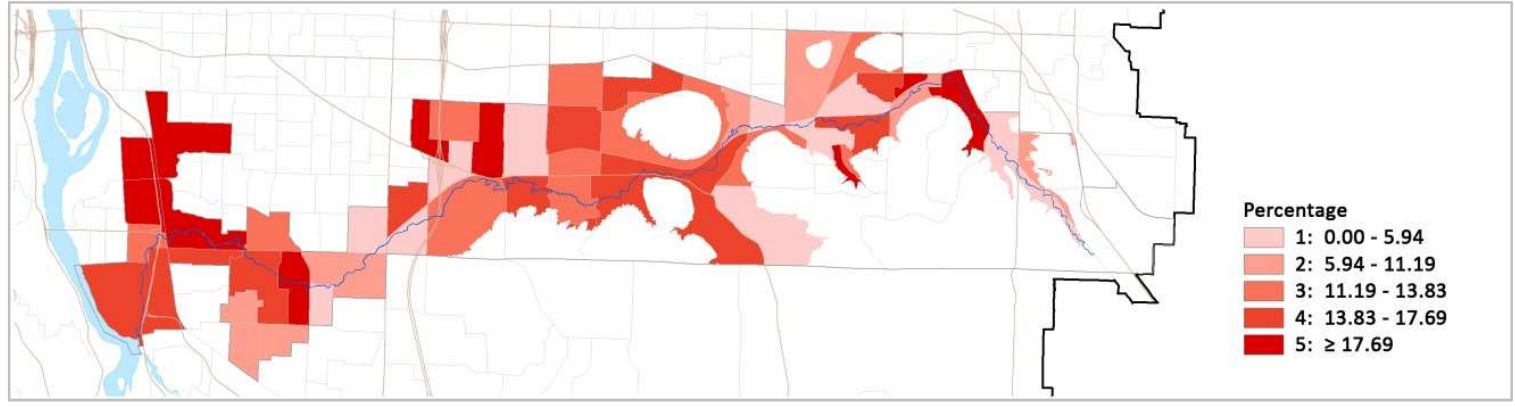

SVI 3: Age

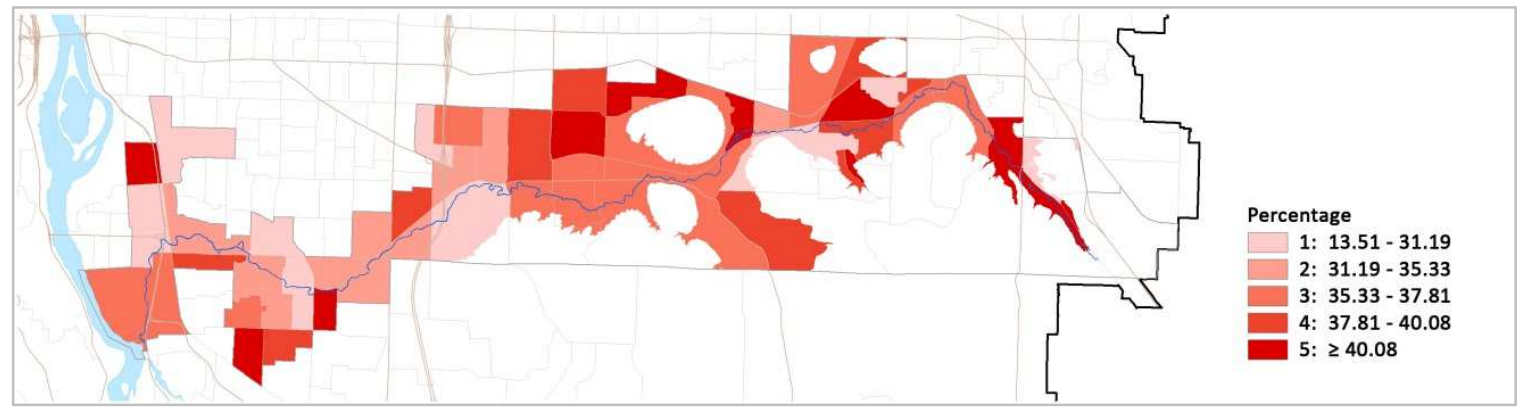

SVI 4: Housing type

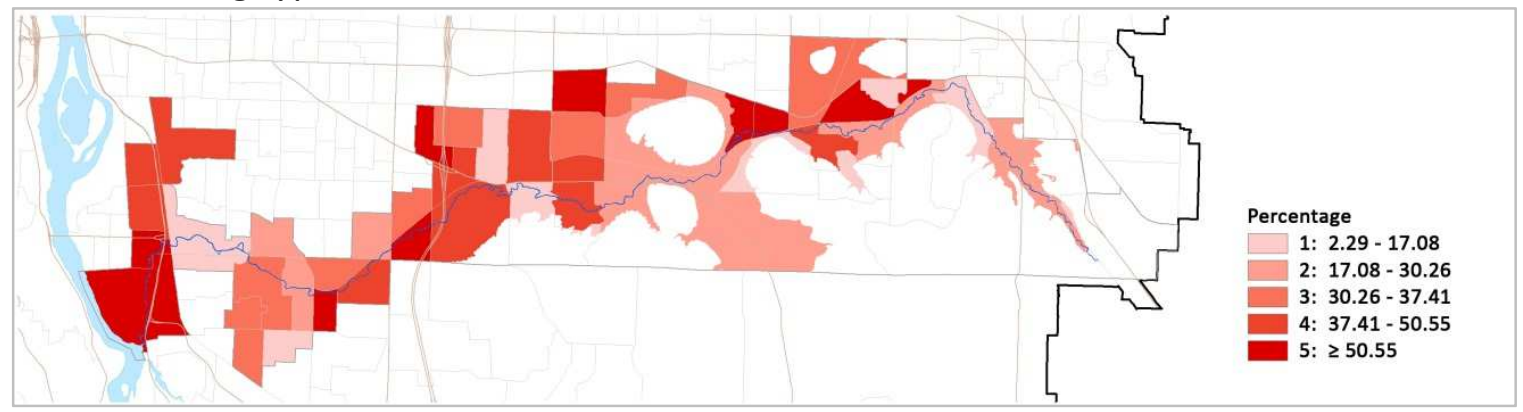


SVI 5: Household size

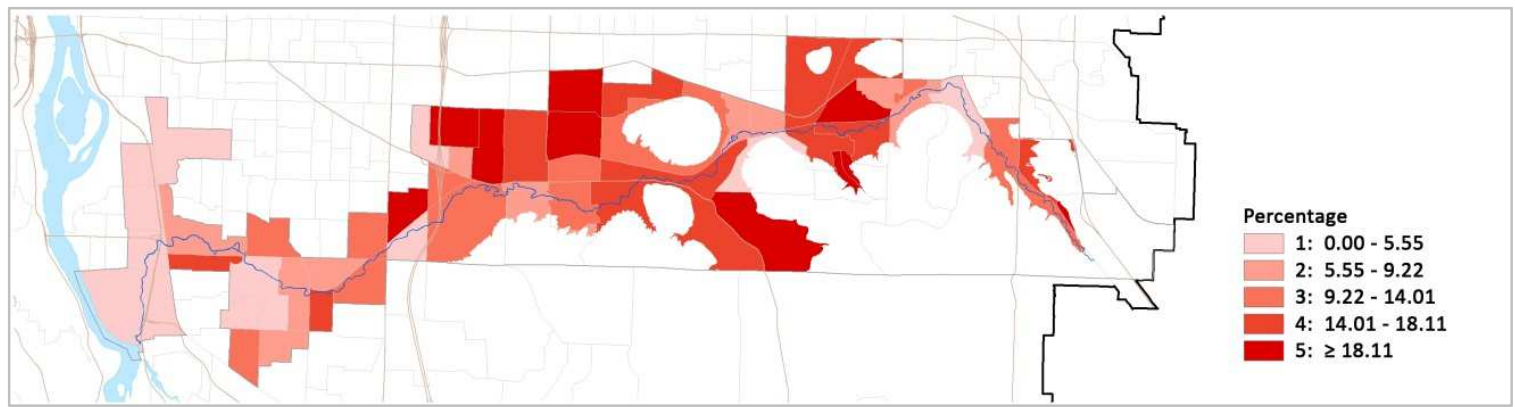

SVI 6: Community of color

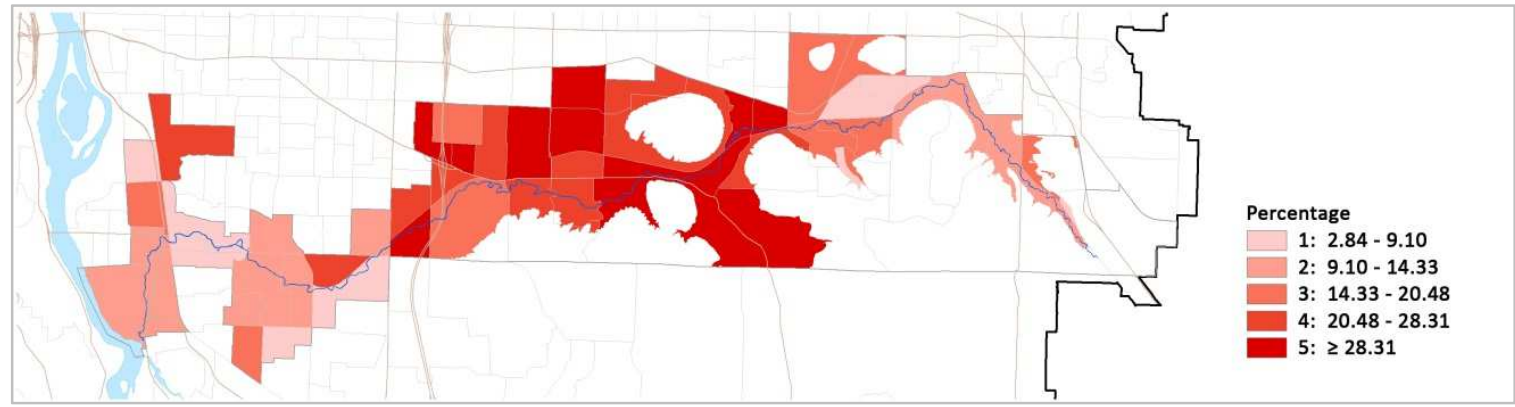

SVI 7: Disability

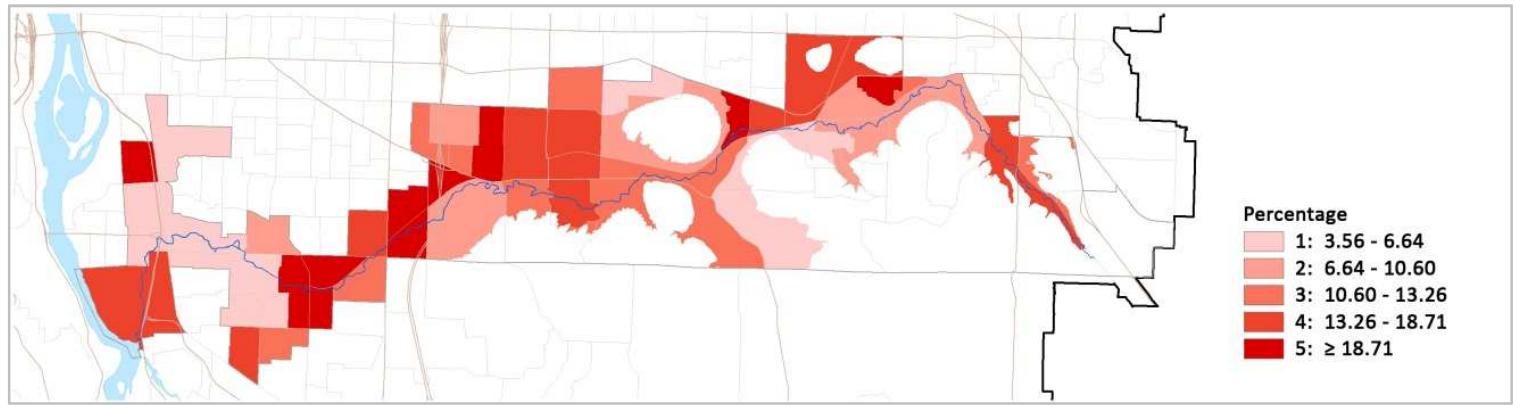

SVI 8: Language

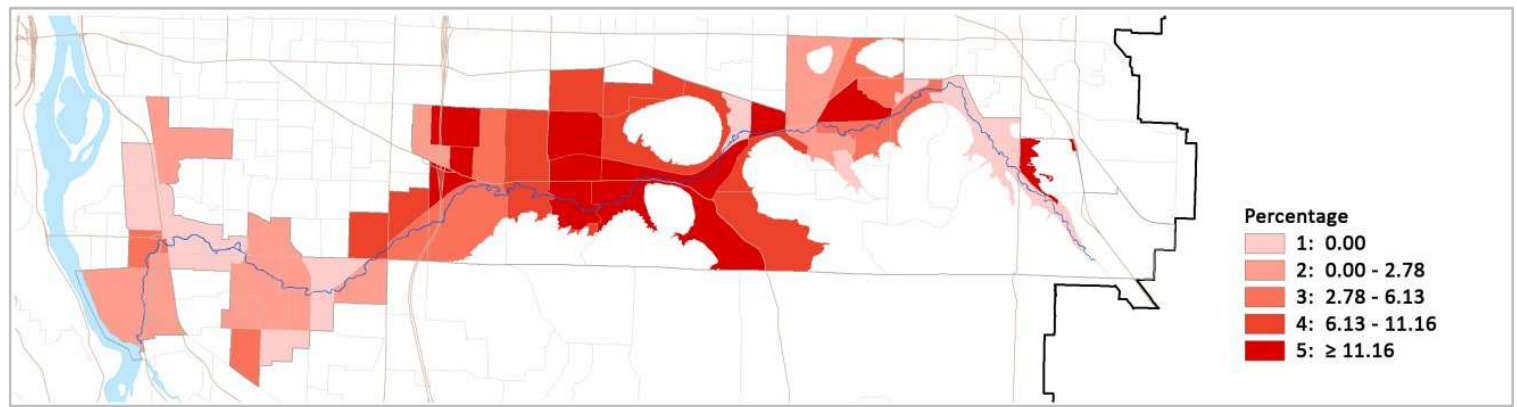


SVI 9: Unemployment

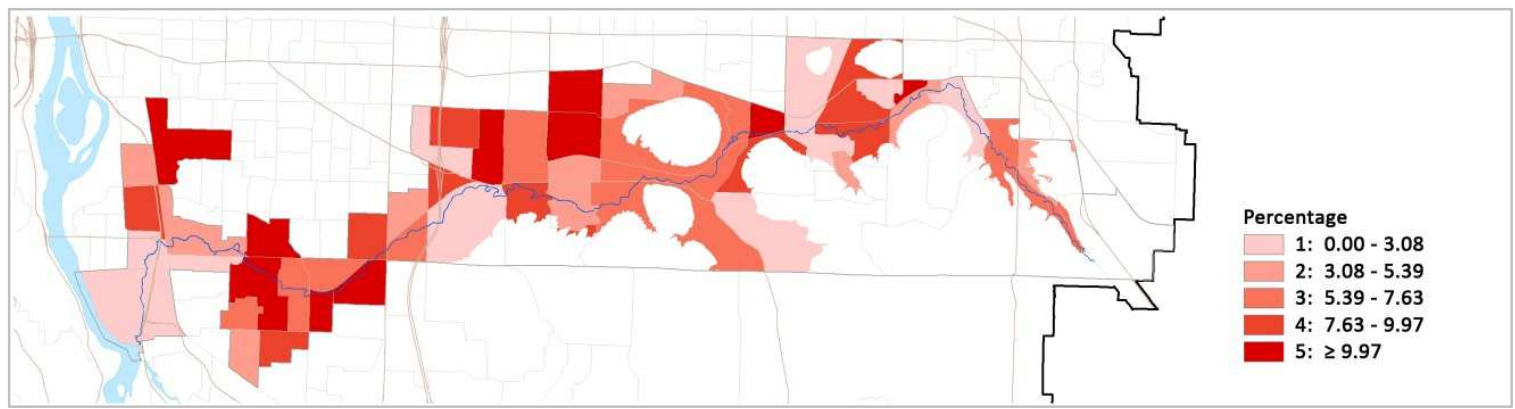

SVI 10: Education

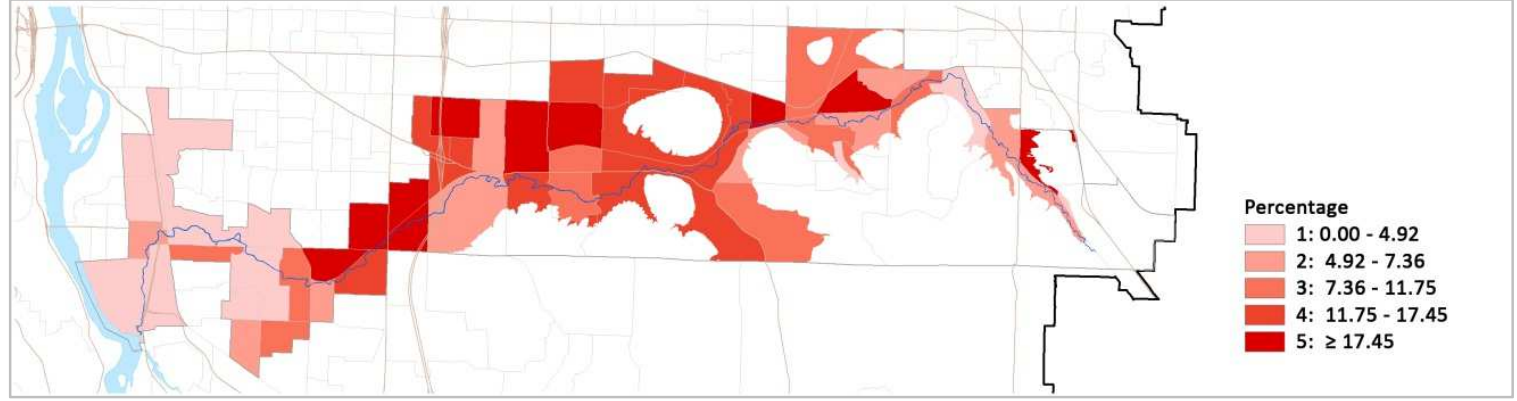


Thank you for agreeing to take part in this interview. Your participation will help me to explore the board range of meanings and understandings that flood experts construct in relation to environmental justice. The interview is divided into two sections and will take approximately 30 to 40 minutes. Your participation is completely voluntary and all the information collected will be kept strictly confidential.

Once again, thank you for your time and sharing your opinions.

Section I: Sorting Q-statements

Q1. Please sort the following 27 statements from 'most important / most agree' (+4) to 'least important / least agree' (-4) when dealing with flood risks.

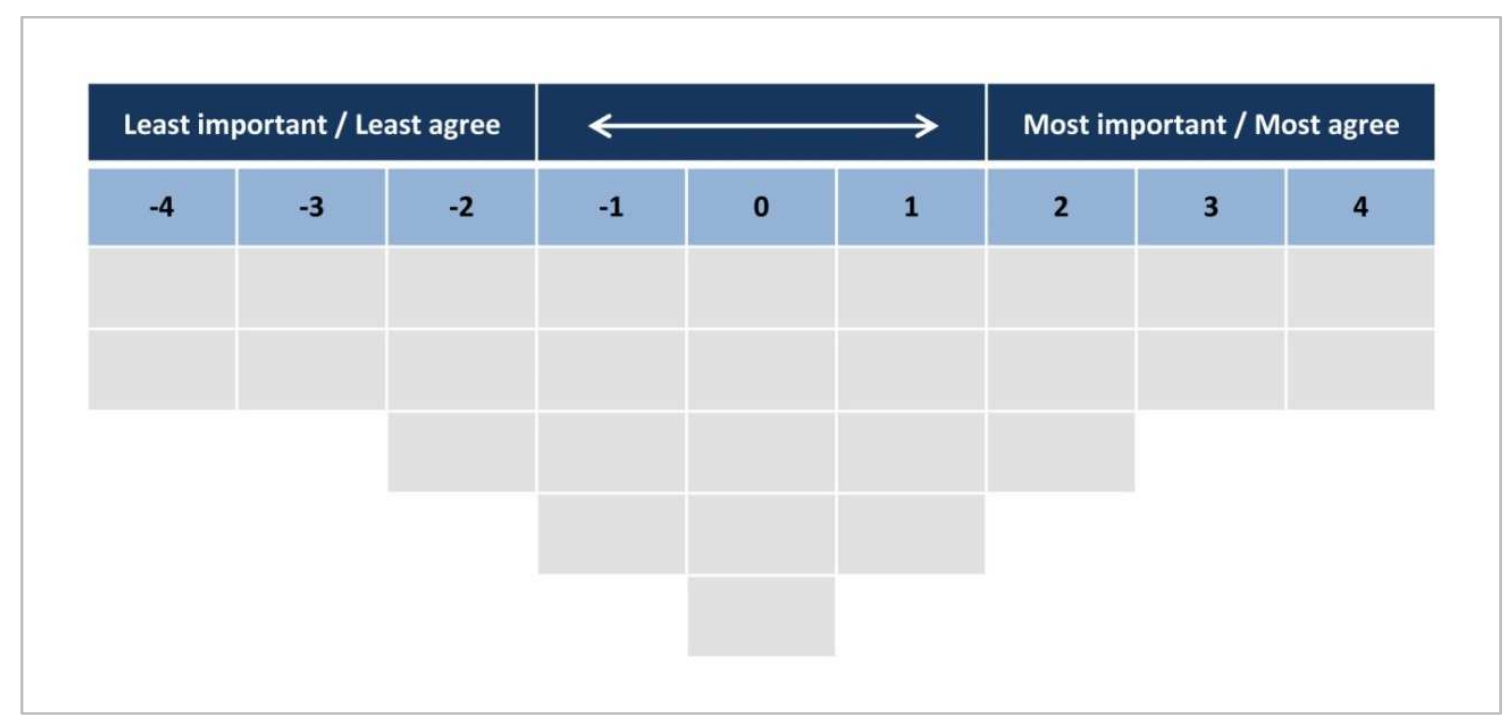

\begin{tabular}{c|l}
\hline No. & \multicolumn{1}{c}{ Q-statements } \\
\hline \hline 1 & $\begin{array}{l}\text { Successful flood risk management depends on the construction and maintenance of } \\
\text { levees, dikes, dams and other water infrastructures. }\end{array}$ \\
\hline 2 & $\begin{array}{l}\text { Local knowledge should be a foundation to public policy in flood risk reduction and } \\
\text { management. }\end{array}$ \\
\hline 3 & $\begin{array}{l}\text { All community members should have equal access to adequate information, resources } \\
\text { and emergency services during flood disasters. }\end{array}$ \\
\hline 4 & $\begin{array}{l}\text { Hydraulic analysis should be taken into account as the most valuable source in flood } \\
\text { mitigation planning. }\end{array}$ \\
\hline 5 & $\begin{array}{l}\text { Individual property rights can be sacrificed for other community member's rights to be } \\
\text { safeguarded from floods and other natural disasters. }\end{array}$ \\
\hline
\end{tabular}




\begin{tabular}{|c|c|}
\hline 6 & $\begin{array}{l}\text { Since political power tends to be asymmetrical, adaptive actions for potential flood } \\
\text { risks can reduce the vulnerability of only those best placed to take advantage of } \\
\text { governance institutions rather than reduce the vulnerability of disempowered } \\
\text { populations. }\end{array}$ \\
\hline 7 & $\begin{array}{l}\text { Flood mitigation policy and planning should be primarily focused on the people who } \\
\text { are poor, disabled, aged or cannot speak English. }\end{array}$ \\
\hline 8 & $\begin{array}{l}\text { As a social dispensation, reducing socioeconomic vulnerability of people needs to be } \\
\text { discussed and achieved mainly through non-governmental organizations and } \\
\text { intermediate groups. }\end{array}$ \\
\hline 9 & $\begin{array}{l}\text { In flood risk management, environmental justice means taking shared responsibility for } \\
\text { promoting human rights of socioeconomically disadvantaged groups in communities. }\end{array}$ \\
\hline 10 & $\begin{array}{l}\text { In situations of flood disasters, government has a moral obligation to provide } \\
\text { humanitarian assistance especially for socioeconomically disadvantaged populations. }\end{array}$ \\
\hline 11 & $\begin{array}{l}\text { Successful flood mitigation planning largely depends on the ability and competence of } \\
\text { flood experts and practitioners. }\end{array}$ \\
\hline 12 & $\begin{array}{l}\text { From an efficiency standpoint, the Willing Seller Land Acquisition Program is a great } \\
\text { way to reduce flood damage and associated financial costs. }\end{array}$ \\
\hline 13 & $\begin{array}{l}\text { It is significant to understand differences in residents' socioeconomic capacity to cope } \\
\text { with flood risks. }\end{array}$ \\
\hline 14 & $\begin{array}{l}\text { Local government should focus on providing education that helps community members } \\
\text { increase their own capacity to withstand flood risks and reduce economic losses. }\end{array}$ \\
\hline 15 & The protection of human rights should not be optional in flood risk management. \\
\hline 16 & $\begin{array}{l}\text { In the process of developing flood mitigation strategies, local residents' opinions should } \\
\text { be considered prior to flood experts' opinions. }\end{array}$ \\
\hline 17 & $\begin{array}{l}\text { In flood policy development and implementation, social and economic inequalities } \\
\text { should be allowed when such inequalities work to the benefit of the least advantaged } \\
\text { members of communities. }\end{array}$ \\
\hline 18 & The primary goal of flood mitigation is to relocate residents out of floodplains. \\
\hline 19 & $\begin{array}{l}\text { It is not only institutional but also individual responsibility to increase abilities to better } \\
\text { cope with flood disasters. }\end{array}$ \\
\hline 20 & $\begin{array}{l}\text { The city budget should be primarily spent on public services that can create the } \\
\text { greatest benefits for the majority. }\end{array}$ \\
\hline 21 & $\begin{array}{l}\text { For successful flood risk management, it is essential to enhance public engagement } \\
\text { through more direct, participatory decision-making mechanisms. }\end{array}$ \\
\hline 22 & $\begin{array}{l}\text { Government should put more efforts on enhancing technological capability to simulate } \\
\text { and predict floods. }\end{array}$ \\
\hline 23 & It is important to consider both physical and socioeconomic vulnerability to flood risks. \\
\hline 24 & $\begin{array}{l}\text { Both structural and nonstructural flood measures should be sustainable and cost } \\
\text { effective so they can help as many people as possible for as long as possible. }\end{array}$ \\
\hline 25 & $\begin{array}{l}\text { Flood inundation extent map (e.g., the FEMA 100-year floodplain map) is the best } \\
\text { indicator for assessing flood vulnerability. }\end{array}$ \\
\hline
\end{tabular}


Flooding is a city-wide problem that requires comprehensive, diversified and systematic city-wide solutions.

27 Flood insurance is not a responsible policy because it does not reduce the damages but merely spreads the monetary loss over a wider population sector.

Section II: Follow-up Questions

Q2. Why did you place these statements in the $+4 /-4$ columns?

Q3. What does environmental justice mean to you and why?

Q4. What would be environmental justice-based solutions to flood disasters?

Q5. What would be the opportunities and challenges for local government to promote environmental justice in flood mitigation policy and planning? 